\title{
Genetic variants of EPO and EPOR influence cognitive core features of schizophrenia
}

\author{
Dissertation \\ for the award of the degree \\ "Doctor rerum naturalium" \\ Division of Mathematics and Natural Science \\ of the Georg-August-Universität Göttingen
}

submitted by

Heidi Friedrichs

from Remscheid

Göttingen 2011 
Doctoral thesis committee: Prof. Dr. Dr. Hannelore Ehrenreich (Advisor, First Referee) Division Klinische Neurowissenschaften

Max-Planck-Institut für Experimentelle Medizin Hermann-Rein-Str. 3

37073 Göttingen

PD Dr. Henning Gibbons (Second Referee)

Juniorprofessor für Biopsychologie

Georg-Elias-Müller-Institute für Psychologie

Goßlerstr. 14

37073 Göttingen

Prof. Dr. Klaus-Armin Nave

Abteilung Neurogenetik

Max-Planck-Institut für Experimentelle Medizin

Hermann-Rein-Str. 3

37073 Göttingen

Date of submission of thesis: January 18, 2011

Date of oral examination: February 21, 2011 
I hereby declare that this thesis has been written independently with no other sources or aids than quoted.

Göttingen, January 18, 2011

Heidi Friedrichs 


\section{Acknowledgments}

I would like to thank Hannelore Ehrenreich for giving me the possibility to work in her division and to study under her supervision. I am very grateful for the help, guidance and numerous opportunities offered during the course of the years. Henning Gibbons and Klaus-Armin Nave, both members of my PhD committee, have always offered valuable input and constructive criticism.

For the genetics' section of this work, I would like to thank Sabrina Grube, and Sergi Papiol for all their work and expertise regarding genetic analyses. A special note of gratitude goes to Martin Begemann for frequent help and caring for the patients as well as their follow ups. Also I would like to thank Ahmed El-Kordi for his work in the behaviour unit including provision of the data on the cEPOR mice.

I am grateful to Anne Kästner for productive discussions and all her help, and to Erin Choi for proofreading. I would like to specially thank Katja Ribbe who not only provided intellectual and emotional support but also created a wonderful working atmosphere.

And last but not least I would like to thank my family and friends for their continuous motivation, encouragement and support. 


\section{Contents}

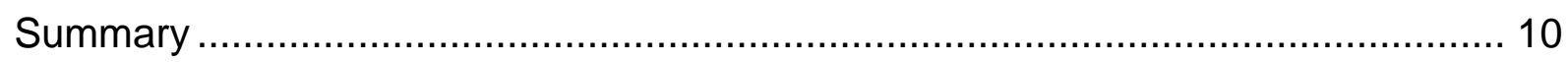

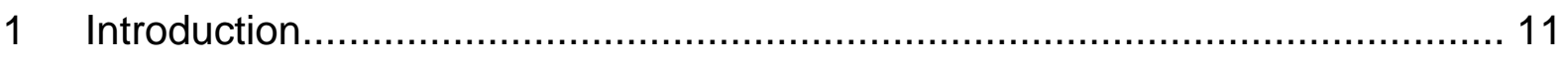

2 Theoretical background .......................................................................... 13

2.1 EPO

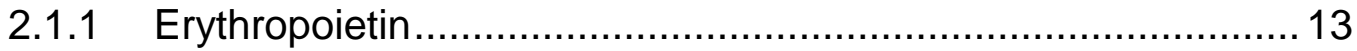

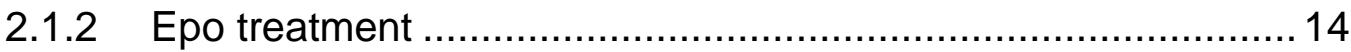

2.1.3 Genes of the Epo system.................................................. 15

2.1.4 Transgenic mouse model...................................................24

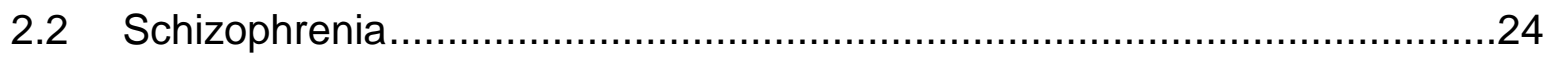

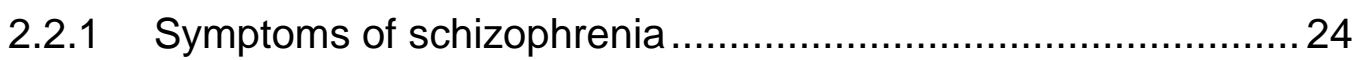

2.2.2 Göttingen Research Association for Schizophrenia (GRAS) ....28

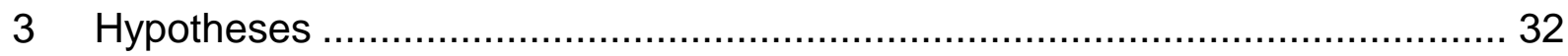

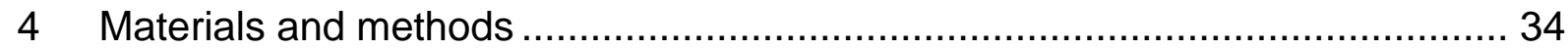

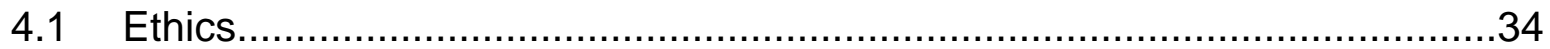

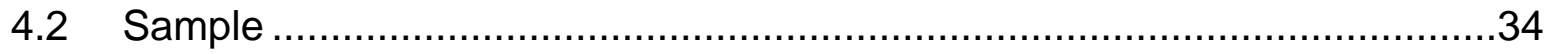

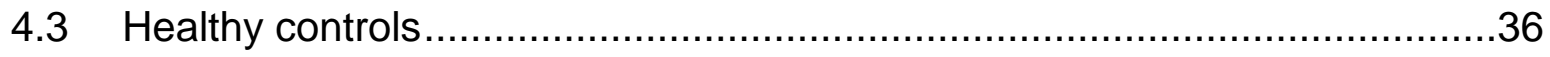

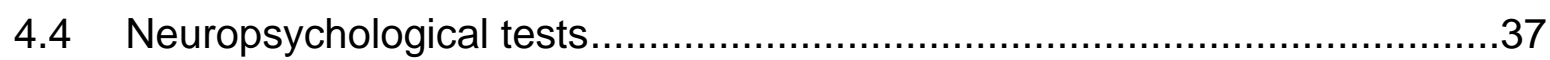

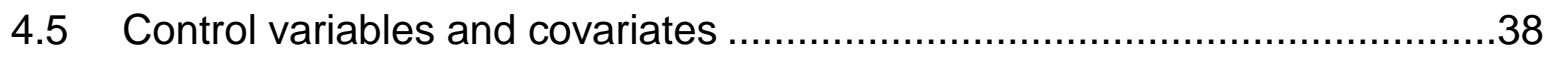

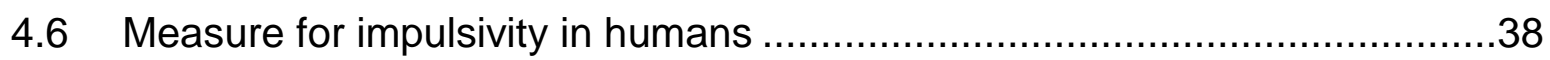

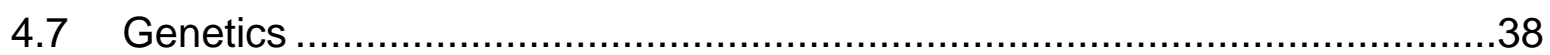

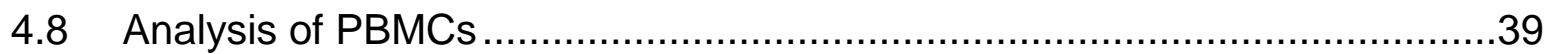

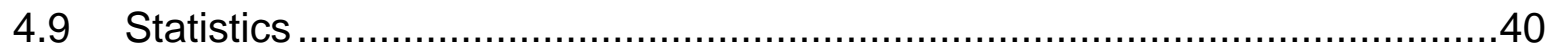

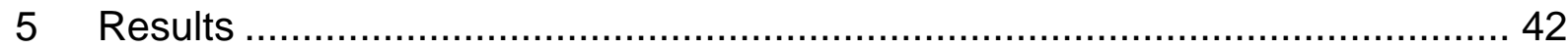

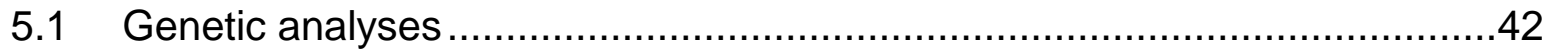

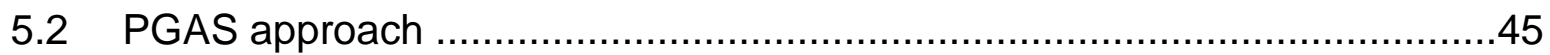

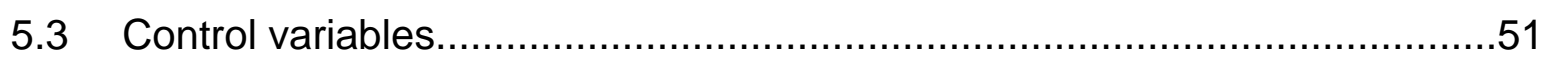

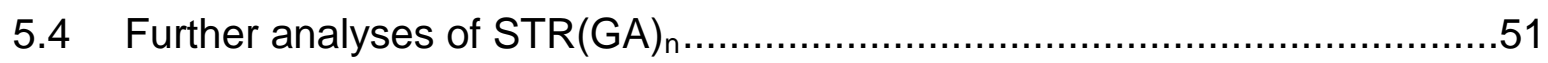

5.4.1 Sum of allelic repeat lengths ................................................... 51

5.4.2 Heterogeneity of allelic repeat lengths .................................. 54

5.5 Exploration of genetic influence on blood levels .......................................54

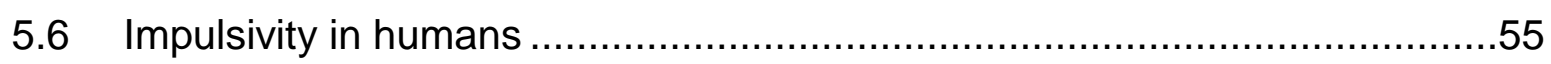

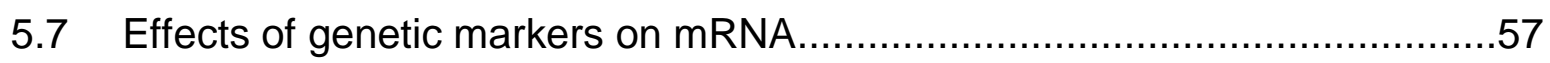

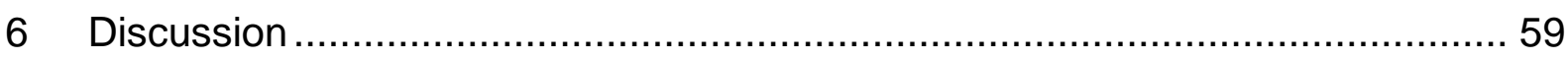

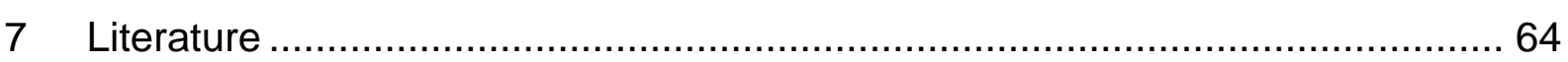




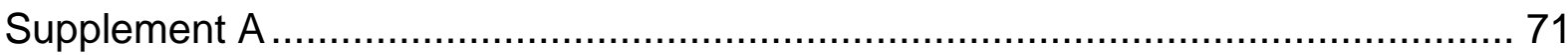

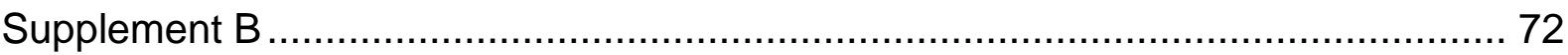

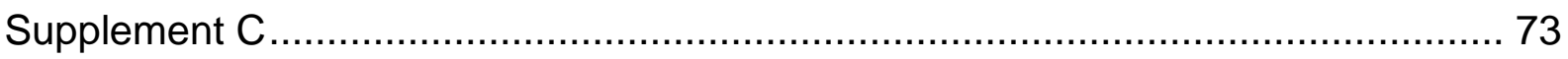

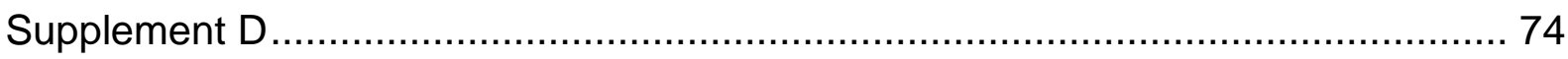

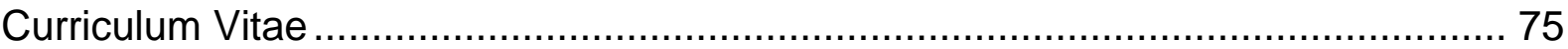




\section{Figures}

Figure 1: Schemes of EPO and EPOR genes

Figure 2: Collaborating centers, visited by the traveling team from the Max Planck Institute of Experimental Medicine.

Figure 3: Overview of the most important domains, in which phenotype information of every patient were collected 30

Figure 4: Flow chart of patients from whom blood indices were collected ................ 36

Figure 5: Distribution of genotypes for SNP rs 1617640 of EPO gene .................... 42

Figure 6: Distribution of genotypes for SNP rs564449 of EPO gene ..................... 43

Figure 7: Distribution of sum of allelic repeat lengths of EPOR STR among cases and controls

Figure 8: Distribution of difference between allelic repeat lengths of EPOR STR among cases and controls

Figure 9: Main effects of EPO SNP and EPOR STR on Cognitive Composite Score 47

Figure 10: Display of the interaction effect of both genetic markers on Cognitive Composite Score 48

Figure 11: Influence of EPO SNP and EPOR STR on Speed of Processing 48

Figure 12: Interaction effect of EPO SNP and EPOR STR on Speed of Processing 49 Figure 13: Main effects of EPO and EPOR markers on Verbal Learning and Memory

Figure 14: Interaction effect of EPO and EPOR on Verbal Learning and Memory ... 50 Figure 15: Effect of EPOR STR split up in four repeat length sum groups on Speed of Processing and Verbal Learning and Memory.... 51

Figure 16: Effect of EPOR four sum groups on the Cognitive Composite Score ...... 52 Figure 17: Interaction of the three EPO SNP genotype groups with four EPOR repeat lengths sum groups 53

Figure 18: Heterogeneity of the four EPOR repeat lengths groups 54

Figure 19: Effect of EPOR repeat separated in high and low sum on impulsivity ..... 56

Figure 20: Association of EPOR STR(GA) $)_{n}$ with impulsivity 57

Figure 21: Effect of EPOR repeat separated in high and low sum on EPO mRNA... 58 Figure 22: Effect of EPOR repeat separated in four different sum groups on EPO mRNA 58 


\section{Tables}

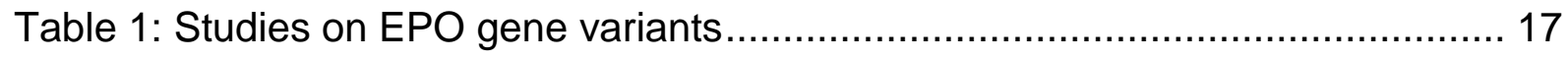

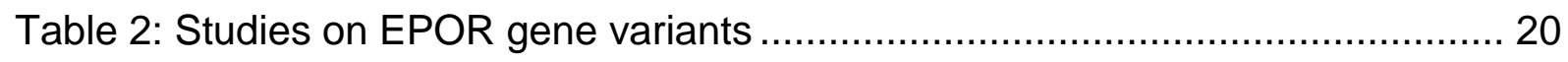

Table 3: Criteria for the diagnosis of schizophrenia (295) according to DSM-IV,

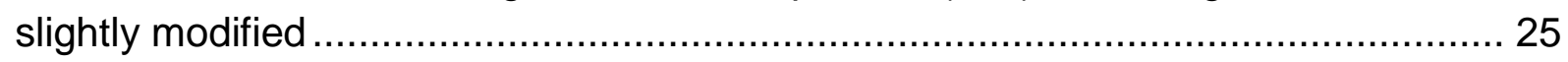

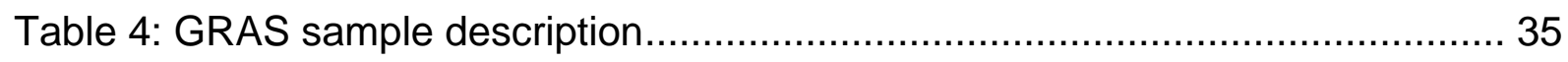

Table 5: Obtained raw data of EPO and EPOR genotype groups in cognitive tests, including percentile rank in relation to normative sample 45

Table 6: Associations of EPO SNP and EPOR STR with target and control variables $(\mathrm{n}=841-945)$.

Table 7: Mean values and standard deviations for blood indices per genotype group 55 


\section{Abbreviations}

5CSRTT - Five Choice Serial Reaction Time Tasks

$\mathrm{CPZ}$ - chlorpromazine

cEPOR - constitutively active EPOR

Epo - erythropoietin

EpoR - erythropoietin receptor

EPO - erythropoietin gene

EPOR - erythropoietin receptor gene

GRAS - Göttingen Research Association for Schizophrenia

GWAS - genome-wide association study

mRNA - messenger ribonucleic acid

MWTB - Mehrfachwahl-Wortschatztest $B$, test to measure premorbid intelligence

PANSS - Positive and Negative Syndrome Scale

PBMCs - peripheral blood mononuclear cells

PFCP - primary familial and congenital polycythemia

PGAS - phenotype-based genetic association study

rhEpo - recombinant human erythropoietin

SNP - single nucleotide polymorphism

STR - short tandem repeat

VLMT - verbal learning and memory test (Verbaler Lern- und Merkfähigkeitstest)

ZST - digit symbol test (Zahlen-Symbol-Test) 


\section{Summary}

Introduction: Erythropoietin (Epo), a hematopoietic growth factor, has long been observed to improve cognition but this effect was attributed to the increase in hemoglobin levels. Even after the discovery of Epo and Epo receptor (EpoR) in brain, it lasted for years until potential direct Epo effects on the brain were explored by in vivo experiments. A large number of preclinical studies followed, essentially devoted to employment of Epo as a neuroprotective agent. Ultimately, clinical trials on patients with schizophrenia or chronic progressive multiple sclerosis as well as on extremely preterm infants, all demonstrating improved cognitive outcome upon Epo treatment, particularly of speed of processing/short-term memory, strongly suggested to consider this growth factor as an important player in neuroplasticity and higher cognition. It was thus hypothesized that a respective relevance of the Epo/EpoR system would also be reflected by genetic variations within the encoding genes (EPO and EPOR). Methods: For addressing this hypothesis, the GRAS (Göttingen Research Association for Schizophrenia) data collection was used, providing a thus far unique ground for phenotype-based genetic association studies (PGAS). GRAS comprises $>1000$ patients diagnosed with schizophrenia or schizoaffective disorder according to DSM-IV. DNA samples of GRAS patients were genotyped for genetic polymorphisms of the EPO and EPOR genes. For all subsequent statistical analyses, age, antipsychotic medication, negative symptoms, and duration of disease were used as covariates. Also, since in a transgenic mouse model with a constitutively active form of EPOR (cEPOR) in the postnatal mouse forebrain, a superior cognitive performance came with a price of enhanced impulsivity, it should be explored whether or not genetic markers of EPO/EPOR are associated with impulsivity in humans. Results: Genotype-phenotype analyses in schizophrenic patients, targeting higher cognition, revealed significant associations of EPO/EPOR variants with processing speed/verbal learning and memory. Interestingly, an interaction effect of the two markers was also detected. In humans, like before already seen in a transgenic mouse model, EPOR-related improved cognition comes at the price of higher impulsivity. Conclusions: The data show that genetic variants of the EPO/EPOR system influence the cognitive and behavioral phenotype of schizophrenic individuals. The interaction effect of these genetic variants may be a useful tool to provide mechanistic insight into the molecular interplay between EPO and EPOR regarding higher cognition and impulsive behavior. 


\section{Introduction}

Schizophrenia is a devastating disease, affecting approximately $1 \%$ of the population. The most popular symptoms of this disease fall under the category of positive symptoms, such as delusions, and hallucinations. For a long time it was thought, that curing these symptoms would cure the disease as a whole. Nowadays it is known that in most cases, the more persistent negative symptoms such as lack of drive and affect, as well as anhedonia are more fatal than positive symptoms. A third major class of symptoms was neglected for a long time: cognitive symptoms. But a recent review in 1996 (Green, 1996) caught the focus of researchers on cognitive decline in schizophrenia. Green showed that the cognitive performance of schizophrenic patients was the best predictor for their functional outcome. Today, cognitive decline is accepted as a core symptom of the disease, which is not influenced by positive symptoms.

In 2004 the Göttingen Research Association for Schizophrenia (GRAS) was established and initiated a huge data collection of schizophrenic patients all over Germany. Patients were interviewed, neuropsychologically tested, examined and gave blood samples for DNA and serum analyses. This data collection gives a great overview and perspective of the disease. It builds the foundation to further understand the mechanisms and associations between the symptoms and features of the disease, also in combination with genetic analyses (see Chapter 2.2).

Since the impact of cognitive decline in schizophrenia on functional outcome measures is known, and therefore its costs for the health care system (Knapp, Mangalore, \& Simon, 2004; Patel, et al., 2006), the search for a treatment in regard to cognition began. So far this search was not thoroughly successful, except for one trial with recombinant human erythropoietin ( $\mathrm{rEEpo}$ ) as an add-on treatment which gave promising results (Ehrenreich, Hinze-Selch, et al., 2007; Wüstenberg, et al., 2010). Erythropoietin (Epo) is a hematopoietic growth factor, named after its role on stimulating erythrocyte progenitor cells to develop. However, in several preclinical studies it could be shown that Epo not only carries beneficial effects on many different symptoms/conditions in animal disease models through its antiapoptotic, anti-inflammatory, angiogenetic, and neuroprotective properties while stimulating neurogenesis, but it is also enhanced cognitive performance in many animal models (Chapter 2.1). 
Since in a treatment trial with chronic schizophrenics Epo enhanced cognitive performance significantly, the idea aroused that genes for EPO and EPO receptor (EPOR) might be disease modifier by influencing cognitive performance. Identifying genes which modify cognition could help to understand the mechanism behind the decline and find a way to delay or even stop this process. 


\section{Theoretical background}

The following chapter will give an introduction into the field of erythropoietin, a hematopoietic growth factor which - as an add-on treatment in brain diseases improved cognitive performance (2.1) and to schizophrenia, one of the most severe psychiatric diseases (2.2).

\subsection{EPO}

The following paragraph will shed light on erythropoietin by first describing the hormone and some of its pathways (2.1.1), then briefly summarizing results of Epo treatment regarding cognitive performance (2.1.2) and afterwards reporting previous findings of the genes for Epo and its receptor (2.1.3) and of a transgenic approach to model a constitutively active Epo receptor in the mouse brain (2.1.4).

\subsubsection{Erythropoietin}

Erythropoietin (Epo) is a circulating glycoprotein hormone named after its regulating function in erythropoiesis. Epo prevents apoptosis and promotes proliferation and differentiation of erythroid progenitor cells in the bone marrow after binding to its receptor. Epo receptor belongs to the cytokine receptor family; upon ligand binding, the receptor dimerizes, Janus kinase 2 (JAK2) is phosphorylated, thereby activating secondary signalling molecules such as signal transducer and activator of transcription 5 (STAT5), the mitogen-activated protein kinases (MAPK) ERK-1/-2, $\mathrm{PI3K} / \mathrm{Akt}$, and the activation/nuclear translocation of nuclear factor ${ }_{-k} \mathrm{~B}\left(\mathrm{NF}_{-\mathrm{K}} \mathrm{B}\right)$ (for reviews see Rabie \& Marti, 2008; Tilbrook \& Klinken, 1999).

Postnatal, Epo is mainly expressed in kidney; additionally liver cells synthesize up to $20 \%$ of the circulating Epo (M. J. Koury, Bondurant, Graber, \& Sawyer, 1988; S. T. Koury, Bondurant, Koury, \& Semenza, 1991). Interestingly, both proteins are also synthesized in the nervous system with a peak in neuronal expression during development (Juul, Yachnis, Rojiani, \& Christensen, 1999) and an upregulation in the adult brain under hypoxic conditions and after injury (Siren, et al., 2001). 


\subsubsection{Epo treatment}

Epo has been clinically used for more than 20 years and has been proven to be well tolerated and safe. Although Epo is originally used to treat anemia, it is more and more considered as an add-on treatment in human brain diseases due to its neuroprotective properties (for reviews see Ehrenreich, Bartels, Sargin, Stawicki, \& Krampe, 2008; Siren, Fasshauer, Bartels, \& Ehrenreich, 2009). In several preclinical studies during the last decade, Epo's potential as treatment of neurological diseases was revealed (for review see Sargin, Friedrichs, El-Kordi, \& Ehrenreich, 2010; attached as Supplement $C$ of the thesis on hand). In cerebrovascular disease models, neuroinflammatory disease models, neurodegenerative disease models, and in models of traumatic brain and spinal cord injury, Epo treatment led in the majority of the studies to an improvement in clinical as well as in neuroprotective/neuroregenerative outcome parameters. Additionally it was shown in several models of cerebrovascular diseases and traumatic brain injury that Epo treatment improved cognition (Sargin, et al., 2010). This effect was for a long time explained as a result of improved tissue oxygenation (Ehrenreich, et al., 2008; Grimm, et al., 1990; Hengemihle, et al., 1996) but cumulated evidence points to an independent Epo effect on the brain (Ehrenreich, et al., 2008).

In addition, clinical studies with Epo could already prove its beneficial effect as neuroprotective and cognitive enhancing agent. In a follow-up study with preterm born infants, Neubauer and colleagues could show a major effect of Epo treatment on cognitive development (Neubauer, Voss, Wachtendorf, \& Jungmann, 2010). Those children who received Epo to stimulate erythropoiesis were more likely to develop cognitively within a normal range than those who did not receive Epo. This cognitive enhancing effect of Epo was also shown in treatment studies with adults, e.g. in patients with multiple sclerosis and patients with chronic schizophrenia (Ehrenreich, Fischer, et al., 2007; Ehrenreich, Hinze-Selch, et al., 2007; Siren, et al., 2009). In the MS exploratory study, it could be shown that cognitive improvement was independent of hemoglobin raise; a clue against the oxygenation hypothesis and towards a separated action of Epo on the brain (Siren, et al., 2009). In the randomized double-blind placebo-controlled study, in which chronic schizophrenics were treated either with placebo or Epo over a twelve week period and tested neuropsychologically, patients who received Epo improved significantly more regarding their cognitive performance than patients who received placebo 
(Ehrenreich, et al., 2007). Most striking results were reached on the subscale of attention, comprising a test for speed of processing. Follow-up MRI measures during this treatment trial in schizophrenia have proven that Epo slowed down the process of grey matter atrophy and even reversed it in some areas (Wüstenberg, et al., 2010). This increase in grey matter volume was correlated with cognitive improvement (especially in regard to speed of processing, immediate memory and working memory), but both beneficial effects were independent of psychopathological symptoms in these patients.

\subsubsection{Genes of the Epo system}

Human genes for EPO and EPOR are located on different chromosomes. The EPO gene lies on chromosome $7 \mathrm{q} 21$ and is stretched over a $2.9 \mathrm{~kb}$ region which contains five exons. The EPOR gene is located on chromosome 19p13.2 and comprises eight exons over a stretch of $6.5 \mathrm{~kb}$. Figure 1 gives a schematic impression of the two genes.

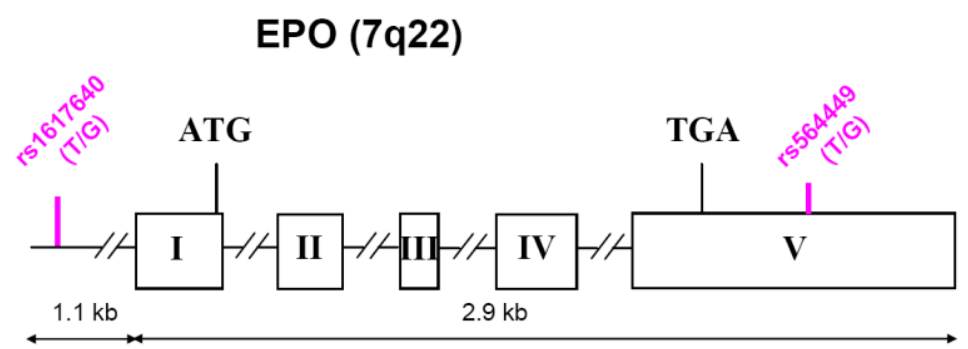

EPOR (19p13.2)

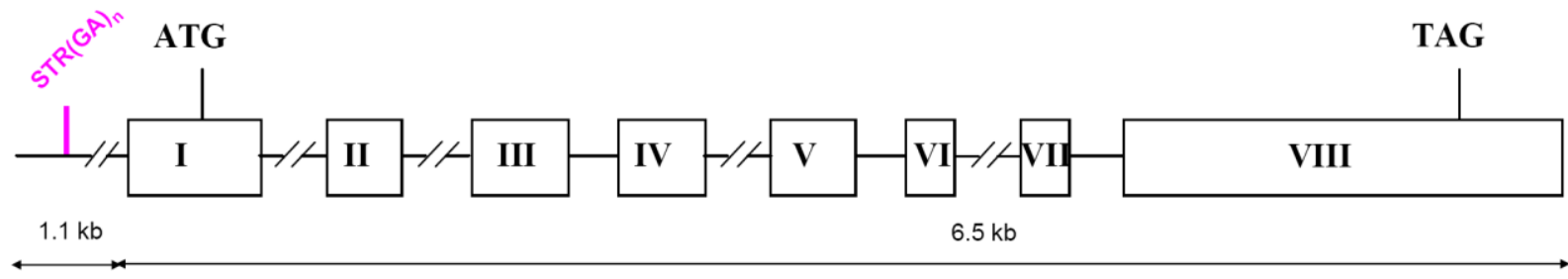

Figure 1: Schemes of EPO and EPOR genes

(marked and labeled polymorphisms are evaluated in the present work)

The EPO gene is highly conserved between species. It was cloned by Jacobs and co-workers in 1985 (Jacobs, et al., 1985). Since then, several association studies attempted to associate the gene with different readouts, of which Table 1 gives an overview. Genetic markers of EPO have been significantly associated with response to high altitude (Jedlickova, et al., 2003), myelodysplastic syndrome (Ma, et al., 2010) 
and proliferative diabetic retinopathy and end stage renal disease (Abhary, et al., 2010; Tong, et al., 2008). The results for diabetic retinopathy are contradictory concerning a single nucleotide polymorphism (SNP) in the promoter region of EPO, rs1617640, and the direction of risk alleles ( $T$ or $\mathrm{G}$ allel associated with higher risk for diabetic retinopathy) whilst in an Indian sample, no association with that SNP and diabetic retinopathy was found at all (Balasubbu, et al., 2010).

In addition to the revealed association of SNP rs1617640 with diabetic retinopathy, the group of Tong and colleagues could show that this SNP rs1617640 in the EPO gene has an influence on Epo protein level in vitreous body with $\mathrm{T}$ homozygotes having a 7.5-fold higher Epo concentration (Tong, et al., 2008). Luciferase reporter expression was even enhanced by 25 -fold with $\mathrm{T}$ allele compared to $\mathrm{G}$ allele. However, in peripheral blood mononuclear cells (PBMCs) no effect of the base pair substitution on Epo mRNA expression could be found (Tong, et al., 2008).

Studies which looked for associations of EPO gene with e.g. erythrocytosis, chronic mountain sickness, hemoglobin E- $\beta$-thalassemia, or amyotrophic lateral sclerosis were not successful so far (Ghezzi, et al., 2009; Mejia, Prchal, Leon-Velarde, Hurtado, \& Stockton, 2005; Percy, McMullin, \& Lappin, 1997; Sripichai, et al., 2005). 
Table 1: Studies on EPO gene variants

\begin{tabular}{|c|c|c|c|c|c|c|}
\hline Authors & Year & Population & Genetic marker(s) & Association/Target & Result & Remarks \\
\hline Percy et al. & 1997 & $\begin{array}{l}12 \text { erythrocytosis patients, } 4 \\
\text { healthy controls }\end{array}$ & $\begin{array}{l}\text { sequencing of a } 256 \mathrm{bp} \\
\text { region 3' to EPO gene }\end{array}$ & erythrocytosis & $\begin{array}{l}4 \text { polymorphisms in cases \& } \\
\text { controls, no association with } \\
\text { erythrocytosis }\end{array}$ & \\
\hline Zeng et al. & 2001 & $\begin{array}{l}247 \text { healthy blood donors from } \\
\text { lowa }\end{array}$ & $\begin{array}{l}\text { STR (CACT) in the third } \\
\text { intron (position 2153) of } \\
\text { the EPO gene }\end{array}$ & $\begin{array}{l}\text { differences between } \\
\text { gender or hematocrit } \\
\text { levels or both } \\
\text { (interaction effect) }\end{array}$ & $\begin{array}{l}\text { no differences; marker } \\
\text { explained neither gender } \\
\text { differences nor differences in } \\
\text { hematocrit level }\end{array}$ & \\
\hline Jedlickova, et al. & 2003 & $\begin{array}{l}48 \text { athletes, } 10 \% \text { Hispanic } \\
\text { origin, } 4 \% \text { African-American } \\
\text { origin, } 86 \% \text { Caucasian origin }\end{array}$ & $\begin{array}{l}4 \text { dinucleotide } \\
\text { polymorphic markers in } \\
\text { EPO gene; } 1 \text { SNP in } \\
\text { 3'HRE of EPO } 3434\end{array}$ & $\begin{array}{l}\text { erythropoietin response } \\
\text { to high altitude }\end{array}$ & $\begin{array}{l}\text { D7S477 repeat } 0.70 \mathrm{Mbp} 3 \\
\text { showed allelic association with } \\
\text { Epo hypoxic response } \\
\text { phenotype }\end{array}$ & $\begin{array}{l}\text { D7S477 not in } \\
\text { congruence with Hardy- } \\
\text { Weinberg equilibrium }\end{array}$ \\
\hline Lin et al. & 2005 & $\begin{array}{l}1702 \text { subjects of } 330 \text { families } \\
\text { from Massachusetts }\end{array}$ & $\begin{array}{l}\text { genome-wide scan for } \\
\text { quantitative trait loci } \\
\text { (QTL) }\end{array}$ & hematocrit levels & no association with EPO gene & $\begin{array}{l}\text { genome-wide association } \\
\text { scan }\end{array}$ \\
\hline Mejia et al. & 2005 & 104 males from Peru (Andean) & $\begin{array}{l}4 \text { microsatellites D7S515, } \\
\text { D7S518, D7S2480, } \\
\text { D7S477 }\end{array}$ & $\begin{array}{l}\text { chronic mountain } \\
\text { sickness (CMS), } \\
\text { polycythemia }\end{array}$ & $\begin{array}{l}\text { no association with analysed } \\
\text { EPO markers }\end{array}$ & \\
\hline Sripichai et al. & 2005 & $\begin{array}{l}1060 \mathrm{Hb} \text { E- } \beta \text {-thalassemia } \\
\text { patients of Asian origin }\end{array}$ & $\begin{array}{l}\text { SNPs rs } 1617640^{*} \\
\text { rs4729606, rs576237 }\end{array}$ & $\begin{array}{l}\text { hemoglobin E- } \beta \text { - } \\
\text { thalassemia }\end{array}$ & no linkage to EPO gene & $\begin{array}{l}\text { rs576237 not polymorphic } \\
\text { in this Thai population }\end{array}$ \\
\hline lliadou et al. & 2007 & $\begin{array}{l}391 \text { pairs of dyzygotic twins } \\
\text { from UK }\end{array}$ & $\begin{array}{l}\text { genome-wide scan for } \\
\text { associations }\end{array}$ & red cell indices & no linkage to EPO gene & $\begin{array}{l}\text { genome-wide association } \\
\text { scan }\end{array}$ \\
\hline Tong et al. & 2008 & $\begin{array}{l}374 \text { patients \& } 239 \text { matched } \\
\text { controls with European- } \\
\text { American origin; } 2 \text { replica } \\
\text { samples with same origin }\end{array}$ & $\begin{array}{l}\text { rs } 1617640^{*} \text { in the } \\
\text { promoter of the EPO } \\
\text { gene }\end{array}$ & $\begin{array}{l}\text { proliferative diabetic } \\
\text { retinopathy (PDR) \& } \\
\text { end stage renal disease } \\
\text { (ESRD) in diabetes } \\
\text { mellitus }\end{array}$ & $\begin{array}{l}\text { the TT genotype of rs } 1617640^{*} \\
\text { was associated with PDR and } \\
\text { ESRD }\end{array}$ & $\begin{array}{l}\text { luciferase reporter } \\
\text { expression } 25 \text {-fold higher } \\
\text { with T-allele than with G- } \\
\text { allele }\end{array}$ \\
\hline
\end{tabular}




\begin{tabular}{|c|c|c|c|c|c|c|}
\hline Ganesh et al. & 2009 & $\begin{array}{l}\text { 24,167 European individuals + } \\
\text { independent replica set of } \\
9,456 \text { European individuals }\end{array}$ & $\begin{array}{l}\text { rs2075671, 7q22.1, } \\
\text { within } 60 \mathrm{~kb} \text { span around } \\
\text { EPO gene }\end{array}$ & 6 erythrocyte traits & $\begin{array}{l}\text { associations for Hct, MCV and } \\
\text { RBC with rs2075671 near the } \\
\text { EPO gene }\end{array}$ & $\begin{array}{l}\text { genome-wide analyses, } \\
\text { no direct association with } \\
\text { EPO gene }\end{array}$ \\
\hline Ghezzi et al. & 2009 & $\begin{array}{l}222 \text { Italian patients, } 204 \\
\text { healthy controls matched for } \\
\text { ethnicity \& age }\end{array}$ & $\begin{array}{l}\text { sequence analysis of } 3 \text { ' } \\
\text { untranslated region with } \\
\text { two polymorphisms } \\
\text { C3434T and G3544T }\end{array}$ & $\begin{array}{l}\text { sporadic amyotrophic } \\
\text { lateral sclerosis (SALS) }\end{array}$ & $\begin{array}{l}\text { no potentially causative } \\
\text { differences between cases and } \\
\text { controls were found }\end{array}$ & $\begin{array}{l}\text { G3544T associated with } \\
\text { age of onset of ALS: TT } \\
\text { having later age of onset }\end{array}$ \\
\hline Abhary et al. & 2010 & $\begin{array}{l}518 \text { subjects with diabetes } \\
\text { mellitus; } 93 \% \text { Europeans, } 7 \% \\
\text { of Asian and Middle Eastern }\end{array}$ & $\begin{array}{l}3 \text { SNPS from EPO gene: } \\
\text { rs507392, rs } 1617640^{*} \text {, } \\
\text { and rs551238 }\end{array}$ & $\begin{array}{l}\text { diabetic retinopathy } \\
\text { (DR) }\end{array}$ & $\begin{array}{l}\text { all SNPs associated with DR } \\
\text { status; identification of disease } \\
\text { haplotype }\end{array}$ & $\begin{array}{l}\text { opposite to Tong (2008): } \\
\text { G allele of rs } 1617640^{*} \\
\text { associated with DR status }\end{array}$ \\
\hline Balasubbu et al. & 2010 & $\begin{array}{l}345 \text { patients with diabetic } \\
\text { retinopathy \& } 356 \text { diabetic } \\
\text { controls all of Indian origin }\end{array}$ & SNP rs $1617640^{*}$ & $\begin{array}{l}\text { diabetic retinopathy } \\
\text { (DR) }\end{array}$ & $\begin{array}{l}\text { no association with DR found in } \\
\text { this population }\end{array}$ & \\
\hline Ma et al. & 2010 & $\begin{array}{l}187 \text { patients with } \\
\text { myelodysplastic syndromes } \\
\text { (MDS) compared to } 813 \\
\text { patients with other types of } \\
\text { leukemia and } 95 \text { healthy } \\
\text { controls, ethnicity unknown }\end{array}$ & SNP rs $1617640^{*}$ & $\begin{array}{l}\text { myelodysplastic } \\
\text { syndromes (MDS) in } \\
\text { comparison to other } \\
\text { types of leukemia }\end{array}$ & association found with MDS & $\begin{array}{l}\text { GG genotype of } \\
\text { rs1617640* associated } \\
\text { with higher risk for MDS } \\
\text { (OR 4.98) }\end{array}$ \\
\hline
\end{tabular}


The EPOR gene was cloned in 1989 from murine erythroleukemia cells (D'Andrea, Lodish, \& Wong, 1989). In Table 2, recent findings from association studies for EPOR gene markers are summarized. No associations of EPOR gene were found so far with Diamond-Blackfan anemia, myeloproliferative disorders, hemoglobin E- $\beta$ thalassemia, chronic mountain sickness or erythropoietin response to high altitude (Dianzani, et al., 1996; Jedlickova, et al., 2003; Mejia, et al., 2005; Mittelman, et al., 1996; Sripichai, et al., 2005). Instead, in many studies polymorphisms and rare mutations of the EPOR gene were associated with primary familiar and congenital polycythemia (PFCP) as well as secondary polycythemia / erythrocytosis (Arcasoy, Degar, Harris, \& Forget, 1997; de la Chapelle, Sistonen, Lehvaslaiho, Ikkala, \& Juvonen, 1993; Furukawa, et al., 1997; Kralovics, Sokol, Broxson, \& Prchal, 1997; Percy, et al., 1998; Petersen, Hokland, Petersen, \& Nyvold, 2004; Sokol, Prchal, \& Prchal, 1993; Watowich, et al., 1999). Regardless, some studies failed to show that association (Bourantas, et al., 2006; Emanuel, et al., 1992; Hess, et al., 1994) or found associations only in some studied cases or families, but not in all (Kralovics, Sokol, \& Prchal, 1998; Sokol, et al., 1995).

Also, several studies explored whether genetic variants of EPO and/or EPOR have an influence on hematocrit, erythrocytes or other blood cell measures (Ganesh, et al., 2009; Iliadou, et al., 2007; Lin, O'Donnell, Levy, \& Cupples, 2005; Zeng, Yankowitz, Widness, \& Strauss, 2001) but failed to show an association. Some studies simply found allele-wise associations with blood cell measures which would not remain after correction for multiple testing (Zeng, et al., 2001) or only found associations with markers close to the EPO gene (Ganesh, et al., 2009). So far there is no evidence for suspecting EPO or EPOR genes to be risk genes for schizophrenia due to its lack of any hit with genome-wide association studies (Duan, Sanders, \& Gejman, 2010; O'Donovan, et al., 2008).

Surprisingly, even though many preclinical studies have shown neuroprotective and neuroregenerative effects of Epo (see Chapter 2.1.2), only one study investigated the effect of EPO/EPOR genes on a disease of the central nervous system, in this case ALS (Ghezzi, et al., 2009). With regard to the cognitive enhancing effect of Epo which was not only in many preclinical studies but also in a few clinical treatment studies found, it is even more remarkable that no one looked for an association of EPO and EPOR genes with cognition until now. 
Table 2: Studies on EPOR gene variants

\begin{tabular}{|c|c|c|c|c|c|c|}
\hline Authors & Year & Population & Genetic marker(s) & Association/Target & Result & Remarks \\
\hline Emanuel et al. & 1992 & $\begin{array}{l}3 \text { unrelated families with } \\
\text { primary familiar and congenital } \\
\text { polycythemia (PFCP) }\end{array}$ & $\begin{array}{l}\text { search for DNA changes } \\
\text { in EPOR and its } 3 \text { ' } \\
\text { untranslated region }\end{array}$ & $\begin{array}{l}\text { primary familiar and } \\
\text { congenital } \\
\text { polycythemia (PFCP) }\end{array}$ & $\begin{array}{l}\text { no chromosomal } \\
\text { rearrangements or gene } \\
\text { amplification in PFCP patients } \\
\text { found }\end{array}$ & \\
\hline $\begin{array}{l}\text { de la Chapelle } \\
\text { et al. }\end{array}$ & 1993 & family $(n=58)$ from Finland & $\begin{array}{l}\text { 182-196bp products from } \\
\text { nucleotides }-618 \text { to }-420 \\
\text { upstream of transcription } \\
\text { initiation site of EPOR } \\
\text { gene, STR }(\mathrm{GA})_{n}{ }^{*}\end{array}$ & familial erythrocytosis & $\begin{array}{l}\text { STR }(G A)_{n}{ }^{*} \text { upstream of the } \\
\text { EPOR gene was in high linkage } \\
\text { with the disease }\end{array}$ & \\
\hline Sokol et al. & 1993 & $\begin{array}{l}3 \text { families with primary familiar } \\
\text { and congenital polycythemia } \\
\text { (PFCP) }\end{array}$ & $\begin{array}{l}\text { search for abnormalities } \\
\text { in structure of EPOR } \\
\text { gene }\end{array}$ & $\begin{array}{l}\text { primary familiar and } \\
\text { congenital } \\
\text { polycythemia (PFCP) }\end{array}$ & $\begin{array}{l}\text { STR }(G A)_{n}{ }^{*} \text { upstream of the } \\
\text { EPOR gene was associated } \\
\text { with the disease }\end{array}$ & $\begin{array}{l}\text { same marker found like } \\
\text { de la Chapelle } 1993\end{array}$ \\
\hline Hess et al. & 1994 & $\begin{array}{l}24 \text { patients with polycythemia } \\
\text { vera }(P V)\end{array}$ & $\begin{array}{l}\text { search for abnormalities } \\
\text { in structure and } \\
\text { expression of EPOR } \\
\text { gene }\end{array}$ & polycythemia vera $(\mathrm{PV})$ & $\begin{array}{l}\text { no structural changes of EPOR } \\
\text { gene in PV }\end{array}$ & \\
\hline Sokol et al. & 1995 & $\begin{array}{l}9 \text { families with primary familiar } \\
\text { and congenital polycythemia } \\
\text { (PFCP) }\end{array}$ & $\begin{array}{l}2 \text { microsatellites } \\
\text { STR }(\mathrm{GA})_{n}{ }^{*} \& \\
\operatorname{STR}(\mathrm{GGAA})_{n} \text { in 5'- } \\
\text { untranslated region }\end{array}$ & $\begin{array}{l}\text { primary familiar and } \\
\text { congenital } \\
\text { polycythemia (PFCP) }\end{array}$ & $\begin{array}{l}\text { linkage with selected genetic } \\
\text { markers in } 2 \text { families found }\end{array}$ & \\
\hline Dianzani et al. & 1996 & $\begin{array}{l}23 \text { patients with Diamond- } \\
\text { Blackfan anemia (DBA), } 21 \\
\text { white, } 1 \text { black, } 1 \text { of East Indian } \\
\text { origin; } 13 \text { of Italian origin, } 8 \\
\text { Canadians }\end{array}$ & $\begin{array}{l}\text { screening its coding } \\
\text { sequence for mutations }\end{array}$ & $\begin{array}{l}\text { Diamond-Blackfan } \\
\text { anemia (DBA) }\end{array}$ & $\begin{array}{l}\text { no causal mutations were } \\
\text { identified, DBA is not commonly } \\
\text { associated with EPOR gene } \\
\text { mutations }\end{array}$ & \\
\hline
\end{tabular}




\begin{tabular}{|c|c|c|c|c|c|c|}
\hline Mittelman et al. & 1996 & $\begin{array}{l}7 \text { healthy controls, } 20 \text { MPD } \\
\text { patients, } 11 \text { MDS patients; } \\
\text { examined in Israel }\end{array}$ & $\begin{array}{l}\text { search for differences in } \\
\text { genetic structure via DNA } \\
\text { digestion with four } \\
\text { different enzymes }\end{array}$ & $\begin{array}{l}\text { myeloproliferative } \\
\text { disorders (MPD) [with/ } \\
\text { without polycythemia } \\
\text { vera (PV)] and } \\
\text { myelodysplastic } \\
\text { syndrome (MDS) }\end{array}$ & $\begin{array}{l}\text { EPOR is intact in MPD and } \\
\text { most patients with MDS; only } \\
\text { one patient with MDS had a } \\
\text { different restriction pattern than } \\
\text { the controls with one enzyme }\end{array}$ & \\
\hline Arcasoy et al. & 1997 & $\begin{array}{l}\text { 3-generation Caucasian family } \\
(n=8)\end{array}$ & $\begin{array}{l}\text { heterozygosity for a } \\
\text { deletion of } 7 \text { nucleotides } \\
\text { between positions } 5985 \\
\text { and } 5991 \text { in exon } 8 \text { of the } \\
\text { EPOR gene }\end{array}$ & $\begin{array}{l}\text { dominantly inherited } \\
\text { familial erythrocytosis }\end{array}$ & $\begin{array}{l}\text { heterozygosity for this mutation } \\
\text { was associated with inherited } \\
\text { familial erythrocytosis }\end{array}$ & $\begin{array}{l}\text { cells expressing mutant } \\
\text { EPOR displayed } 5 \text { to } 10 \text { - } \\
\text { fold increased sensitivity } \\
\text { to Epo }\end{array}$ \\
\hline Furukawa et al. & 1997 & Japanese family & $\begin{array}{l}\text { screening for mutations in } \\
\text { exons VII and VIII }\end{array}$ & $\begin{array}{l}\text { primary familiar and } \\
\text { congenital } \\
\text { polycythemia (PFCP) }\end{array}$ & $\begin{array}{l}\text { heterozygosity for C \& T at } \\
\text { position } 5986 \text { (point mutation C- } \\
\text { T on one allel) associated with } \\
\text { PFCP }\end{array}$ & \\
\hline Kralovics et al. & 1997 & $\begin{array}{l}27 \text { unrelated subjects with } \\
\text { (primary) polycythemia of } \\
\text { Caucasian origin }\end{array}$ & $\begin{array}{l}\text { screening for mutations in } \\
\text { exons VII and VIII }\end{array}$ & $\begin{array}{l}\text { primary familiar and } \\
\text { congenital } \\
\text { polycythemia (PFCP) }\end{array}$ & $\begin{array}{l}\text { mutations in association with } \\
\text { PFCP found; 7bp-deletion } \\
\text { (del5985-5991) in one family, } \\
\text { 5967insT in a second family }\end{array}$ & \\
\hline Kralovics et al. & 1998 & 3-generation family $(n=8)$ & $\begin{array}{l}\text { screening for mutations; } \\
\text { found C5964G mutation } \\
\text { in exon VIII, resulting in a } \\
\text { truncated EPOR protein }\end{array}$ & $\begin{array}{l}\text { primary familiar and } \\
\text { congenital } \\
\text { polycythemia (PFCP) }\end{array}$ & $\begin{array}{l}\text { C5964G mutation induces } \\
\text { increased proliferative response } \\
\text { to EPO }\end{array}$ & $\begin{array}{l}\text { no clear linkage between } \\
\text { mutation and PFCP, } \\
\text { unaffected family } \\
\text { member also carries } \\
\text { mutation }\end{array}$ \\
\hline Percy et al. & 1998 & 1 English boy & $\begin{array}{l}\text { de novo transition } \\
\text { mutation of } G \text { to } A \text { at } \\
\text { nucleotide } 6002 \text {, leading } \\
\text { to a loss of } 70 \text { amino } \\
\text { acids from the carboxy } \\
\text { terminus }\end{array}$ & erythrocytosis & $\begin{array}{l}\text { associated with erythrocytosis } \\
\text { in this single case }\end{array}$ & $\begin{array}{l}\text { same mutation (G6002A) } \\
\text { was found and linked to } \\
\text { erythrocytosis in a } \\
\text { Finnish family (de la } \\
\text { Chapelle et al., 1993) }\end{array}$ \\
\hline
\end{tabular}




\begin{tabular}{|c|c|c|c|c|c|c|}
\hline Watowich et al. & 1999 & Swedish family & $\begin{array}{l}\text { tandem duplication of } \\
\text { nucleotides 5968-5975, } \\
\text { leading to a truncation of } \\
79 \text { amino acids from the } \\
\text { C-terminus }\end{array}$ & $\begin{array}{l}\text { familial erythrocytosis } \\
\text { (FE) }\end{array}$ & $\begin{array}{l}\text { association with dominant } \\
\text { familial erythrocytosis (FE) }\end{array}$ & $\begin{array}{l}\text { FE caused by hyper- } \\
\text { responsiveness of } \\
\text { receptor-mediated } \\
\text { signalling pathways; } \\
\text { dominant with respect to } \\
\text { normal EPOR signalling }\end{array}$ \\
\hline Zeng et al. & 2001 & $\begin{array}{l}247 \text { healthy blood donors from } \\
\text { lowa }\end{array}$ & $\begin{array}{l}\text { STR }(G G A A)_{n} \text { at }-548 b p \\
\text { from the ATG start codon }\end{array}$ & $\begin{array}{l}\text { differences between } \\
\text { gender or hematocrit } \\
\text { (Hct) levels or both } \\
\text { (interaction effect) }\end{array}$ & $\begin{array}{l}\text { alleles of STR(GGAA })_{n} \\
\text { associated with Hct based on } \\
\text { gender and/or Hct level }\end{array}$ & $\begin{array}{l}\text { results would not remain } \\
\text { after correction for } \\
\text { multiple testing }\end{array}$ \\
\hline Jedlickova, et al. & 2003 & $\begin{array}{l}48 \text { athletes, } 10 \% \text { Hispanic } \\
\text { origin, } 4 \% \text { African-American } \\
\text { origin, } 86 \% \text { Caucasian origin }\end{array}$ & $\begin{array}{l}\text { microsatellite STR }(\mathrm{GA})_{n}{ }^{*} \\
\text { in 5' untranslated region }\end{array}$ & $\begin{array}{l}\text { erythropoietin response } \\
\text { to high altitude }\end{array}$ & no association & \\
\hline Petersen et al. & 2004 & $\begin{array}{l}6 \text { members of a Danish family } \\
\text { and } 1 \text { unrelated healthy control } \\
\text { subject }\end{array}$ & $\begin{array}{l}\text { screening exon VIII of } \\
\text { EPOR gene for changes }\end{array}$ & $\begin{array}{l}\text { primary familiar and } \\
\text { congenital } \\
\text { polycythemia (PFCP) }\end{array}$ & $\begin{array}{l}3 \text { affected members had } \\
\text { deletion of } 5938-5941 \mathrm{bp} \\
\text { resulting in truncation of } 58 \\
\text { amino acids of the C-terminal } \\
\text { part of the protein }\end{array}$ & $\begin{array}{l}\text { the found deletion } \\
\text { introduced the same stop } \\
\text { codon as seen in another } \\
\text { PFCP family (Kralovics et } \\
\text { al. 1997) }\end{array}$ \\
\hline Lin et al. & 2005 & $\begin{array}{l}1702 \text { subjects of } 330 \text { families } \\
\text { from Massachusetts }\end{array}$ & $\begin{array}{l}\text { genome-wide scan to } \\
\text { search for quantitative } \\
\text { trait loci (QTL) }\end{array}$ & hematocrit levels & no association with EPOR gene & $\begin{array}{l}\text { genome-wide association } \\
\text { scan }\end{array}$ \\
\hline Mejia et al. & 2005 & 104 males from Peru (Andean) & $\begin{array}{l}\text { microsatellite } \operatorname{STR}(\mathrm{GA})_{n}{ }^{*} \\
\text { in } 5 \text { ' untranslated region }\end{array}$ & $\begin{array}{l}\text { chronic mountain } \\
\text { sickness (CMS), variant } \\
\text { of acquired } \\
\text { polycythemia }\end{array}$ & $\begin{array}{l}\text { no association with analysed } \\
\text { EPOR marker }\end{array}$ & \\
\hline Sripichai et al. & 2006 & $\begin{array}{l}1060 \mathrm{Hb} \text { E- } \beta \text {-thalassemia } \\
\text { patients of Asian origin }\end{array}$ & $\begin{array}{l}\text { SNPs rs2291516, } \\
\text { rs316500 }\end{array}$ & $\begin{array}{l}\text { hemoglobin E- } \beta- \\
\text { thalassemia }\end{array}$ & no association with disease & $\begin{array}{l}\text { rs316500 not } \\
\text { polymorphic in this Asian } \\
\text { population }\end{array}$ \\
\hline
\end{tabular}




\begin{tabular}{|c|c|c|c|c|c|c|}
\hline Bourantas et al. & 2006 & $\begin{array}{l}8 \text { families with familiar } \\
\text { polycythemia of Greek origin }\end{array}$ & $\begin{array}{l}\text { search for mutations in } \\
\text { the exon VIII }\end{array}$ & familiar polycythemia & $\begin{array}{l}\text { no point mutation in exon VIII of } \\
\text { the EPOR gene }\end{array}$ & \\
\hline lliadou et al. & 2007 & $\begin{array}{l}391 \text { pairs of dyzygotic twins } \\
\text { from UK }\end{array}$ & $\begin{array}{l}\text { genome-wide scan for } \\
\text { associations }\end{array}$ & red cell indices & no linkage to EPOR gene & $\begin{array}{l}\text { genome-wide association } \\
\text { scan }\end{array}$ \\
\hline
\end{tabular}

*genetic marker evaluated in the present work 


\subsubsection{Transgenic mouse model}

In a transgenic mouse model it could be shown that Epo has an effect on cognition independent of its role in the hematopoietic system: Transgenic mice expressing constitutively active EPOR (cEPOR) in pyramidal neurons of cortex and hippocampus show a superior cognitive phenotype compared to wildtypes (Sargin, et al., submitted). Thus, this mouse model delivers the proof that increased Epo levels in the periphery are not required for the cognitive improvement after Epo treatment as suggested by some authors (see Chapter 2.1.2). There is however an erythropoiesis independent effect of Epo in the brain. Having Epo receptors in pyramidal neurons of the cortex and hippocampus which can dimerize and activate their downstream cascade without binding of Epo, resulted in better performance of the mice in almost all cognitive tests. The only exception was found in the Five Choice Serial Reaction Time Tasks (5CSRTT), where - under high cognitive challenge - cEPOR mice made more premature responses, which were rated as mistakes. To put it in other words, these animals paid for their cognitive advantage with enhanced impulsivity. This behavioural finding was confirmed in the marble burying test, a simpler test for impulsivity. Also in this test cEPOR mice showed higher levels of impulsivity by burying significantly more marbles compared to wildtype mice.

\subsection{Schizophrenia}

In the following passage, the psychopathology of schizophrenia is introduced with a focus on cognitive decline (2.2.1). Further on, the Göttingen Research Association for Schizophrenia (GRAS) is presented with its unique multicenter cross-sectional sample of schizophrenic patients and its scientific approach (2.2.2).

\subsubsection{Symptoms of schizophrenia}

To receive the diagnosis of schizophrenia, at least two out of five characteristic symptoms must be prominent for a given period of time (see Table 1). All possible combinations of characteristic symptoms which lead to one and the same diagnosis already give an impression, how multifaceted this disease really is (criterion A). 
Table 3: Criteria for the diagnosis of schizophrenia (295) according to DSM-IV, slightly modified

A. Characteristic symptoms: Two of the following, each present for a significant portion of time during a 1-month period:

1. delusions

2. hallucinations

3. disorganized speech

4. grossly disorganized or catatonic behavior

5. negative symptoms

B. Social/occupational dysfunction: For a significant portion of the time, one or more major areas of functioning (e.g. work, interpersonal relations, or self-care) are markedly below the level achieved prior to the onset

C. Duration: Continuous signs of the disturbance persist for at least 6 months. This 6-month period must include at least 1 month of symptoms that meet criterion A and may include periods of prodromal or residual symptoms

D. Schizoaffective and mood disorder exclusion

E. Substance/general medical condition exclusion: The disturbance is not due to the direct physiological effects of a substance (e.g., a drug of abuse, a medication) or a general medical condition

F. Relationship to a pervasive developmental disorder

Even though, cognitive decline in schizophrenia was one of the first reported features in this disease ("dementia praecox"; Kraepelin, 1893), it is not (yet) integrated in recent diagnostic criteria of DSM-IV and ICD-10 (American Psychiatric Association, 1994; World Health Organization, 1992; Keefe \& Fenton, 2007; Barch \& Keefe, 2010). The most important problem may potentially be to identify the decline, since one needs the comparison between the cognitive level prior to and after the onset of the disease and it is rare that a comprehensive cognitive test battery was carried out before the disease onset.

Palmer and colleagues approached that topic when writing their paper entitled "Is it possible to be schizophrenic yet neuropsychologically normal?" (Palmer, et al., 
1997). They tried to find the answer by allowing two blinded raters judge the performance in schizophrenics as well as in healthy controls. Impairments in five or more tested domains were considered not to be "neuropsychologically normal" anymore. According to that definition, only $28 \%$ of the examined patients with schizophrenia fell into the normal range which led the authors to consider the potential existence of a biological subgroup of patients. Later, Keefe and colleagues showed convincingly that being neuropsychologically normal did not mean that no cognitive decrement took place (Keefe, Eesley, \& Poe, 2005). They had a closer look at predicted cognitive performance upon premorbid intelligence. If estimates of cognitive performance were based on premorbid intelligence and maternal education, nearly all $(98.1 \%)$ of the patients did not fulfil the expected cognitive performance. Therefore, Palmers question finally got answered from Wilk and colleagues by publishing a paper with the title "No, it is not possible to be schizophrenic yet neuropsychologically normal" (Wilk, et al., 2005). In their own study they showed that Palmers proceeding did not take into account whether or not the patterns of performance in different cognitive domains differed between healthy controls and schizophrenics; in their own study they found significant differences between cases and controls concerning these cognitive "profiles" (Wilk, et al., 2005). Regarding the course of the cognitive decline in schizophrenia, a longitudinal neuropsychological follow-up study showed that is relatively stable (Hoff, et al., 1999). Only little evidence was found for a deterioration of cognitive abilities in the first few years of illness with an exception for verbal learning and memory, where significantly less improvement was shown (Hoff, et al., 1999).

Nowadays it is a widely accepted fact that cognitive impairments are a core feature of schizophrenia since they are longitudinally stable, specific for the diagnosis of schizophrenia, reliable as a predictor of functional outcome, already feasible in drugnaïve patients with a first episode of schizophrenia and they are independent of positive symptoms (Elvevag \& Goldberg, 2000; Green, 1996, 2006; Heinrichs \& Zakzanis, 1998; Saykin, et al., 1994). Findings of (1) cognitive impairments which already take place before the onset of psychotic symptoms (Reichenberg, et al., 2002) and (2) significant impairments in relatives of schizophrenic patients (Cannon, et al., 2000) undermined the idea of a genetic root/cause of the cognitive reduction. 
Its impact on the functional outcome in schizophrenia, on community outcome, social problem solving, and skill acquisition (Bellack, Sayers, Mueser, \& Bennett, 1994; Buchanan, Holstein, \& Breier, 1994; Corrigan, Green, \& Toomey, 1994), is especially of huge interest for clinicians and researchers since schizophrenia is an expensive disease and treating the positive symptoms did not help most of the patients to regain an acceptable functional level (Hegarty, Baldessarini, Tohen, Waternaux, \& Oepen, 1994; Knapp, et al., 2004).

In his review Green could show that verbal memory was the strongest predictor for the functional outcome in schizophrenia (Green, 1996); it had an impact on all three previously mentioned categories of functioning (community outcome, social problem solving, and skill acquisition) whilst surprisingly, positive symptoms failed completely to have an effect on them. Therefore, Green calls verbal memory performance in schizophrenia as a "rate-limiting factor", meaning it restricts the functioning of the patients. It was shown in further studies that differences in memory performance between healthy controls and schizophrenics result from problems in the encoding phase, measured by the total acquisition rate (Cirillo \& Seidman, 2003; Gold, et al., 2000; Javitt, Strous, Grochowski, Ritter, \& Cowan, 1997; Koh, Kayton, \& Berry, 1973), therefore it is also a measure for the learning impairment in schizophrenia. Saykin and colleagues could show, that deficits in verbal memory are already present at an early stage of the disease and they account for most of the variance between patients and controls (Saykin, et al., 1994). In a meta-analysis about neuropsychological domains in schizophrenia, the effect size for "global verbal memory" including summary indices such as total acquisition rate, was the largest among all 22 analysed tests and domains reviewed (Heinrichs \& Zakzanis, 1998). Therefore it is worthwhile to say that verbal declarative memory is "a core deficit in schizophrenia" (Cirillo \& Seidman, 2003).

Brébion and colleagues found negative correlations between processing speed and the encoding performance in verbal memory tasks in schizophrenic patients (Brébion, Amador, Smith, \& Gorman, 1998; Brébion, et al., 2000), meaning that slower speed of processing (measured with a digit symbol task) lead to deficits in organizing verbal stimuli. The idea of speed of processing as the cognitive core process determining a broader diversity of cognitive disturbances was further supported in a study in which if used as a covariate - speed of processing neutralized differences between cases 
and controls in tasks of verbal memory, attention and working memory (RodriguezSanchez, Crespo-Facorro, Gonzalez-Blanch, Perez-Iglesias, \& Vazquez-Barquero, 2007). It seems as if the two domains of verbal learning and memory and speed of processing are complementing one another, like they were two distinct parts of one system.

Additionally, speed of processing may be a critical component of neuropsychological vulnerability to schizophrenia since anomalies have been found in schizophrenic patients (psychotic and remitted) as well as in biological relatives (Nuechterlein, Dawson, \& Green, 1994). In a recent meta-analysis a mean effect for digit symbol coding of -1.57 in case-control comparisons was revealed which was significantly larger than effects for all other, widely used cognitive measures (Dickinson, Ramsey, \& Gold, 2007). This led Dickinson to the conclusion that "information processing inefficiency is a central feature of the cognitive deficit in schizophrenia" (Dickinson, et al., 2007).

\subsubsection{Göttingen Research Association for Schizophrenia (GRAS)}

\section{GRAS data collection}

The Göttingen Research Association for Schizophrenia (GRAS) was founded in 2004 with the aim to further explore and understand the disease, its roots and mechanisms. For this purpose, much information was collected from a huge cohort of schizophrenic/schizoaffective patients in 23 collaborating centers all over Germany (see Figure 2). 


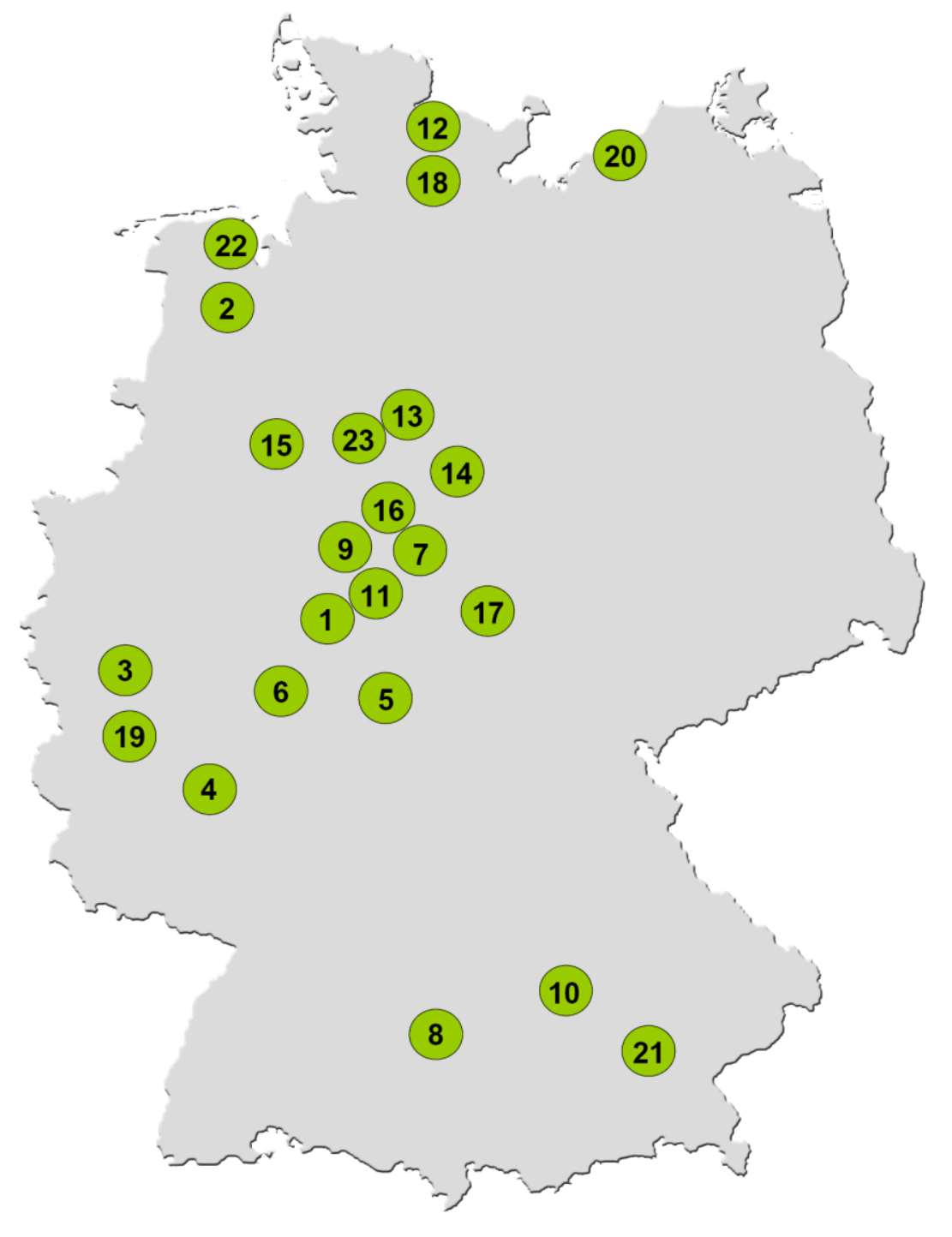

\begin{tabular}{|c|c|c|}
\hline & center (city) & numbers of recruited patients \\
\hline 1. & Bad Emstal-Merxhausen & $241(22.2 \%)$ \\
\hline 2. & Bad Zwischenahn & $40(3.7 \%)$ \\
\hline 3. & Bonn & $19(1.8 \%)$ \\
\hline 4. & Eltville-Eichberg & $20(1.8 \%)$ \\
\hline 5. & Fulda & $30(2.8 \%)$ \\
\hline 6. & Giessen-Haina & $36(3.3 \%)$ \\
\hline 7. & Göttingen & $114(10.5 \%)$ \\
\hline 8. & Günzburg & $31(2.9 \%)$ \\
\hline 9. & Hofgeismar & $10(0.9 \%)$ \\
\hline 10. & Ingolstadt & $27(2.5 \%)$ \\
\hline 11. & Kassel & $19(1.8 \%)$ \\
\hline 12. & Kiel & $26(2.4 \%)$ \\
\hline 13. & Langenhagen & $24(2.2 \%)$ \\
\hline 14. & Liebenburg & $27(2.5 \%)$ \\
\hline 15. & Lübbecke & $30(2.8 \%)$ \\
\hline 16. & Moringen & $4(0.4 \%)$ \\
\hline 17. & Mühlhausen & $53(4.9 \%)$ \\
\hline 18. & Rickling & $56(5.2 \%)$ \\
\hline 19. & Rieden & $91(8.4 \%)$ \\
\hline 20. & Rostock & $80(7.4 \%)$ \\
\hline 21. & Taufkirchen & $32(2.9 \%)$ \\
\hline 22. & Wilhelmshaven & $27(2.5 \%)$ \\
\hline 23. & Wunstorf & $48(4.4 \%)$ \\
\hline \multicolumn{2}{|c|}{ total number of patients } & 1085 \\
\hline
\end{tabular}

Figure 2: Collaborating centers, visited by the traveling team from the Max Planck Institute of Experimental Medicine. 
Between the years 2005 and 2008, 1071 patients with an ex ante diagnosis of their health care providers of schizophrenia or schizoaffective disorder were introduced to an invariant team of traveling investigators from the Max Planck Institute of Experimental Medicine in Göttingen. Patients with the respective diagnosis who were willing to voluntarily take part in the investigation, and gave written informed consent after detailed information, were then interviewed, tested, examined and gave a blood sample for DNA and serum analyses (detailed description of carried out investigations see Ribbe, Friedrichs, et al., 2010; attached as Supplement D). Since the end of the traveling period in 2008, steady-state recruitment is being pursued in Göttingen and yielded so far in a total number of 1085 examined patients. Since the ex ante diagnosis of schizophrenia or schizoaffective disorder was in some cases not confirmed by the GRAS team of investigators, as to this time point information about 1037 patients with approved diagnoses of schizophrenia or schizoaffective disorder have been carefully explored, double-checked and entered. The total amount of collected information resulted ultimately in a most comprehensive data bank with a unique accumulation of more than 3000 data points per patient. Figure 3 gives an impression of the different domains the GRAS collection possesses information about.

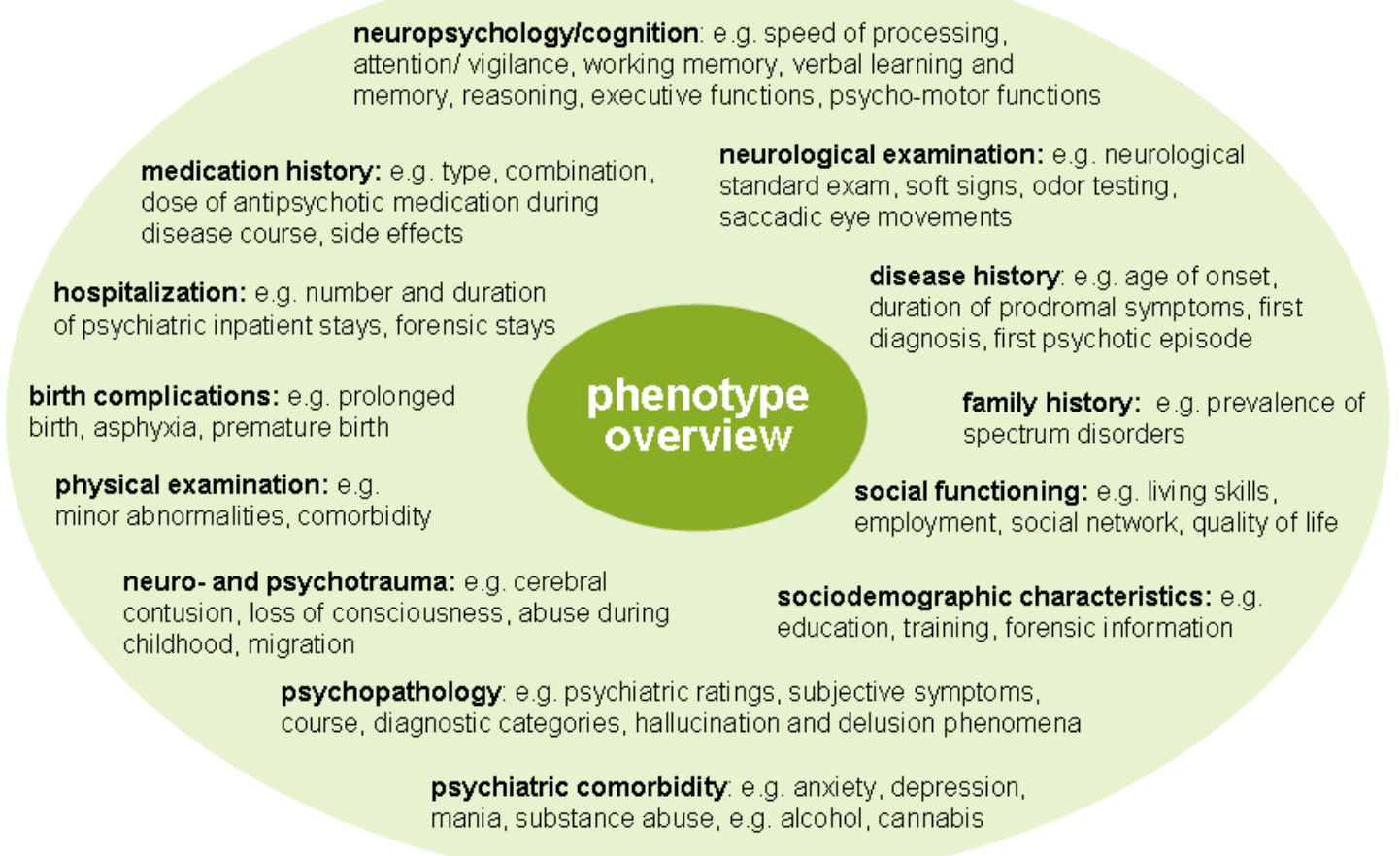

Figure 3: Overview of the most important domains, in which phenotype information of every patient were collected 
In addition to carrying out interviews and examinations, all discharge letters from every inpatient stay in psychiatry of every participating patient were collected. These charts were an important instrument to (1) confirm all the patients' statements and (2) to allow judgement about longitudinal information about the patients' disease, e.g. age at prodromal onset, age at onset of psychotic symptoms, lifetime substance abuse, treatment history, frequency and duration of psychiatric inpatient stays. For more detailed information about the high quality of collected data, their internal consistency and the power of this study see Ribbe, Friedrichs, et al. (2010). To conclude, the collected data gives a most comprehensive overview of the state of schizophrenia in Germany and provides the ground for phenotype-based genetic association studies.

\section{GRAS scientific approach}

In contrast to recent GWAS studies, which search genome-wide for differences in genetic markers between case and control populations (Hardy \& Singleton, 2009), the GRAS approach focuses much more on the specific contribution of a single gene to the disease phenotype. Therefore it is named phenotype-based genetic association study (PGAS) to underline that instead of comparing samples only in regard to end-point diagnosis, PGAS studies search hypothesis-driven for phenotypes within a population (in the thesis on hand the schizophrenic GRAS population) which are modulated by selected genetic markers. Already first publications were able to demonstrate proof-of-concept of the PGAS approach (Begemann, et al., 2010; Papiol, et al., 2011; Grube, et al., submitted; Ribbe, et al., submitted). 


\section{Hypotheses}

As a result of careful literature research and reasonable conclusions made of previous findings, five hypotheses were derived to be checked in the thesis on hand.

(1) In recent GWAS studies, regions of EPO gene and EPOR gene were never characterized as being associated with schizophrenia (see Chapter 2.1.3), therefore it is also assumed that there is no difference in allelic distribution of chosen markers for both genes between schizophrenics and healthy controls.

Hypothesis 1: $\quad$ EPO/EPOR genes are not associated with schizophrenia (no disease genes)

(2) In treatment studies with Epo compounds it was shown that they improve cognitive performance in rodent disease models and human brain diseases (Chapter 2.1.2). Furthermore, in a transgenic approach it could be found that transgenic mice expressing constitutively active Epo Receptors in pyramidal neurons in the hippocampus and cortex revealed superior cognitive results compared to wildtype mice. It was assumed that genetic variants of the EPO system are associated with the cognitive performance in a schizophrenic sample. Based on previous work it was assumed that in schizophrenic patients, particularly the cognitive domains of speed of processing and immediate memory are sensitive towards changes in the EPO system (Ehrenreich, Hinze-Selch, et al., 2007; Wüstenberg, et al., 2010). Therefore, it is supposed that genetic polymorphisms of the EPO system are modulating the performance in both domains in the GRAS population.

Hypothesis 2: $\quad$ Common genetic variants of EPO/EPOR genes are associated with the cognitive domains of 'speed of processing' and 'verbal learning and memory' in schizophrenic patients

(3) Since Epo is a hormone which - after binding to its receptor - stimulates erythrocyte precursor cells in the bone marrow to differentiate, it can not be excluded that genetic variants in this gene or in its receptor gene may influence levels of hemoglobin, hematocrit, erythrocytes, and/or thrombocytes. Even though, researchers failed to detect an association of EPO and EPOR genes with different 
blood indices so far (see Chapter 2.1.3), such an association cannot be excluded without testing it in the GRAS population.

Hypothesis 3: $\quad$ There might be an association between these genetic variants and certain blood indices (hemoglobin, hematocrit, erythrocytes, and thrombocytes)

(4) One finding from the above and in chapter 2.1.4 mentioned transgenic mouse model was that these mice with constitutively active Epo receptors in pyramidal neurons have to pay for their cognitive superiority with an enhanced impulsivity under cognitive challenge. This finding presumes that there is also a possible association between genetic variants of EPO or EPOR genes with impulsivity in humans.

Hypothesis 4: $\quad$ Genetic variants of the EPO system which influence cognition should also have an influence on impulsivity

(5) Tong and colleagues showed an influence of a polymorphism in EPO gene on EPO mRNA in vitreous body (Tong, et al., 2008). Since in treatment studies, patients improved cognitively after receiving externally high doses of rhEpo, it seems reasonable that polymorphisms of EPO/EPOR genes which presumably influence cognitive performance might do that by affecting mRNA levels.

Hypothesis 5: $\quad$ There might be an association between genetic variants of the EPO system and their mRNA levels in periphery 


\section{Materials and methods}

In this chapter, all used materials and methods for the thesis on hand are described in detail, such as ethical approval (4.1), sample characteristics (4.2), information about healthy controls (4.3), neuropsychological tests (4.4), control variables and covariates (4.5), measure for impulsivity (4.6), genetics (4.7), analyses of PBMCs (4.8) and information about used statistics (4.9).

\subsection{Ethics}

The GRAS data collection has been approved by the ethical committee of the GeorgAugust-University of Göttingen (master committee) as well as by the respective local regulatories/ethical committees of all collaborating centers.

\subsection{Sample}

Of the 1085 patients recruited for the GRAS study up to this point (see chapter 2.2.2), only those with confirmed diagnosis of schizophrenia or schizoaffective disorder were included. Table 4 gives an overview of the sample, of some socio-demographic characteristics as well as obtained values in the below mentioned variables of interest. 


\begin{tabular}{|c|c|c|}
\hline & n (\%) & mean (sd) \\
\hline Total sample & $1037(100 \%)$ & \\
\hline Males & $693(66.8 \%)$ & \\
\hline Females & $344(33.2 \%)$ & \\
\hline \multicolumn{3}{|l|}{ Diagnosis } \\
\hline Schizophrenia & $852(82.2 \%)$ & \\
\hline Schizoaffective disorder & $185(17.8 \%)$ & \\
\hline \multicolumn{3}{|l|}{ Ethnicity } \\
\hline Caucasian & $992(95.6 \%)$ & \\
\hline African & $7(0.7 \%)$ & \\
\hline Mixed & $10(1.0 \%)$ & \\
\hline Unknown & $28(2.7 \%)$ & \\
\hline Age & & $39.52(12.56)$ \\
\hline Duration of disease (years) & & $13.23(10.71)$ \\
\hline \multicolumn{3}{|l|}{ PANSS } \\
\hline Positive Symtoms & & $13.76(6.32)$ \\
\hline Negative Symptoms & & $18.23(7.85)$ \\
\hline General Psychopathology & & $33.73(11.83)$ \\
\hline PANSS Total Score & & $65.64(23.40)$ \\
\hline Global Assessment of Functioning (GAF) & & $45.76(17.25)$ \\
\hline Number of siblings & & $1.91(1.75)$ \\
\hline Premorbid Intelligence ${ }^{1}$ & & $26.04(6.20)$ \\
\hline \multicolumn{3}{|l|}{ Cognitive target measures } \\
\hline Speed of Processing & & $37.83(13.12)$ \\
\hline Verbal Learning and Memory ${ }^{1}$ & & $41.66(12.78)$ \\
\hline
\end{tabular}

${ }^{1}$ for all analyses with speech-dependent readouts, non-German speakers $(n=89)$ were excluded

From a subsample of the GRAS cohort, samples of peripheral blood mononuclear cells (PBMCs) were taken to further analyse mRNA status of respective genes of interest $(n=35)$. Also, from every GRAS patient who had stayed as an inpatient in the department of psychiatry in the University Medical Center of Göttingen ( $n=102)$, 
results of every blood test which was taken between January 2000 and June 2010 were collected. Five had to be excluded due to medical conditions (see Figure 4), and for the remaining 97 patients, mean values of hemoglobin, hematocrit, erythrocytes and thrombocytes were calculated from all collected results (between one and 48 per patient), outliers and extreme values within individual patients (both lying more than 1.5 interquartile ranges [middle $50 \%$ of scores] from the normal range) were excluded.

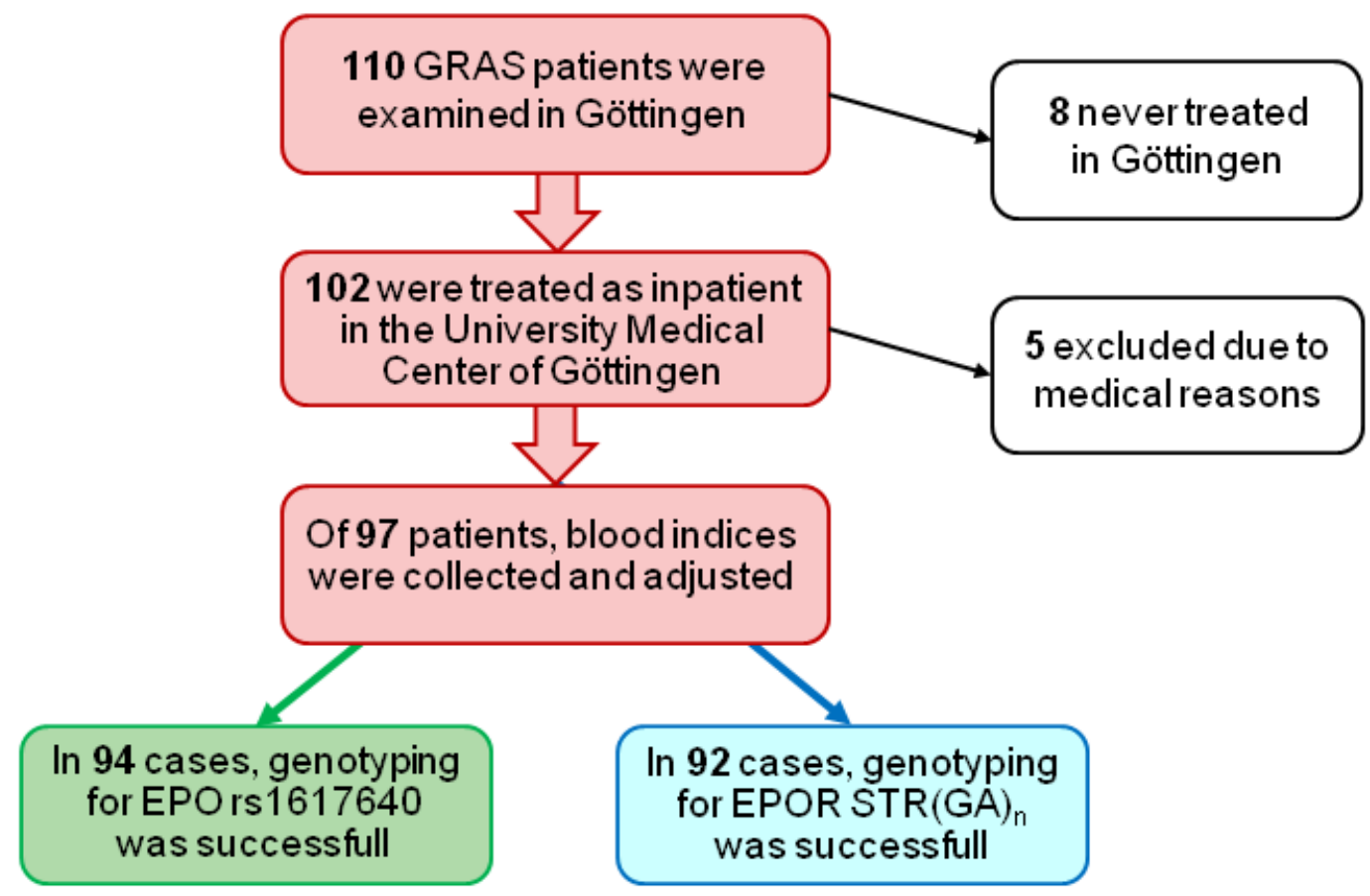

Figure 4: Flow chart of patients from whom blood indices were collected

\subsection{Healthy controls}

For reassessment of whether or not the selected genetic markers are associated with schizophrenia, blood samples from 1143 healthy subjects who gave written informed consent, were used. The sample consists of 673 male $(58.9 \%)$ and 470 female (41.1\%) blood donors with an average age of $34.6 \pm 12.3$ years (range from 18 to 69 years). Participation as healthy controls for the GRAS sample was anonymous, with information restricting to age, gender, blood donor health state and ethnicity. Comparable to the patient population, almost all control subjects were of European Caucasian descent (Caucasian 97.8\%; other ethnicities 2\%; unknown $0.2 \%$ ). 


\subsection{Neuropsychological tests}

From the most comprehensive neuropsychological test battery used in the GRAS study, the most appropriate conducted test from each domain of interest was chosen: The Digit-Symbol Test (ZST, subtest of HAWIE-R, Tewes, 1991; German version of WAIS-III, Wechsler, 1997) was applied to measure the speed of processing and ability to concentrate. The task is to translate lines of digits into symbols according to a displayed digit-symbol-code, where every digit has a different symbol. The task stops after 90 seconds, and the readout is the number of correct translations (test sheet attached as Supplement A). Reliability of the Digit-Symbol Test was measured via test time bisection with Spearman-Brown correction and revealed a Cronbach's alpha of .95 (Tewes, 1991); also test-retests reliability tends to run high with correlation coefficients in a range of .82 - .88 (Matarazzo \& Herman, 1984; Wechsler, 1981). In comparison to a healthy control population used to obtain normalized data for this test, mean values of the GRAS population obtain a percentile rank of 16 , indicating a considerably worse performance in schizophrenics (for more details see Ribbe, Friedrichs, et al., 2010).

To measure the encoding part in a verbal learning and memory task, the general learning score from the Verbal Learning and Memory Test (VLMT, Helmstaedter, Lendt, \& Lux, 2001; German version of the Auditory-Verbal Learning Test, Rey, 1958) was used. In this task a list of 15 words is read five times to the proband, who should say which words he can remember after every run. The number of correct answers from the five runs is summed up and used as readout for the "total acquisition" or encoding performance (test evaluation sheet attached as Supplement B). Reliability of the total acquisition rate was measured with alternate forms of the VLMT with a mean retest interval of eight to twelve months and lies in a range of $r_{\mathrm{tt}}=.81$ to 82 (Helmstaedter, et al., 2001). Obtained mean values from the GRAS population reach a percentile rank of 10 compared to the normalizing sample of healthy controls, again implying poorer performance in schizophrenia (again, for more details see Ribbe, Friedrichs, et al., 2010). 


\subsection{Control variables and covariates}

In addition to the two cognitive target variables, three carefully chosen variables are used as control target variables, on which an influence of the analysed genetic markers is not expected. For the cognitive control variable a measure for premorbid intelligence (MWTB, Lehrl, 1999) was chosen, for a disease-related control variable the clinical rating of global functioning (GAF, AmericanPsychiatricAssociation, 1994) and lastly as disease-unrelated control variable the number of siblings was used.

Age as an important influencing factor of cognitive performance (Kern, et al., 2008) is used as a covariate. Additionally, neuroleptic medication measured in chlorpromazine equivalents (Davis, 1976), duration of disease in years and negative symptoms (measured with the Positive and Negative Syndrome Scale (PANSS): Negative symptoms subscale, Kay, Fiszbein, \& Opler, 1987) which were shown to have an influence on cognition in schizophrenic patients (Ribbe, Friedrichs, et al., 2010) are applied as covariates.

\subsection{Measure for impulsivity in humans}

Impulsivity in the GRAS human population was operationalized with item number 14 "Poor impulse control" of the PANSS General Psychopathology Scale, which was rated by the examiners of the GRAS team of investigators, trained in psychopathological ratings. This item is described as to measure "disordered regulation and control of action on inner urges, resulting in sudden, unmodulated, arbitrary, or misdirected discharge of tension and emotions without concern about consequences" (Kay, et al., 1987). It was rated on a scale from one to seven, with one for the lowest and seven for the highest degree in impulsivity.

\subsection{Genetics}

Two selected SNPs rs1617640 and rs564449 of the human EPO gene (hEPO) were analysed using Simple Probes (TIB Molbiol, Berlin, Germany) and using the LightCycler ${ }^{\circledR} 480$ Genotyping Software implemented in the LightCycler® 480 system (Roche, Mannheim, Germany). The reaction mixture (10 $\mu$ l) was prepared with 20ng of DNA in 384 well plates according to standard protocols (Roche). In each run, 8 
positive controls (hgDNA, Bioline, Luckenwalde, Germany) and negative water blanks were included for quality and internal control purposes. Overall, successfully genotyped markers amounted to $99.7-99.9 \%$.

The polymorphic GA repeat in the promoter region of human EPOR gene (hEPOR) was amplified from genomic DNA by PCR. Primers were chosen according to the paper of de la Chapelle and colleagues (de la Chapelle, et al., 1993):

hEPOR_(GA) forward: 5'- FAM GGT GAC AGA GCA ACA CCC TG-3' hEPOR_(GA) reverse: 5'- $\quad$ ATC AGC ATC TCT TCC CAG CC -3'

resulting in a PCR fragment of $\sim 186 \mathrm{bp}$. For each sample, the reaction mixture $(20 \mu \mathrm{L})$ was prepared in 384 well plates, each containing $20 \mathrm{ng}$ of human genomic

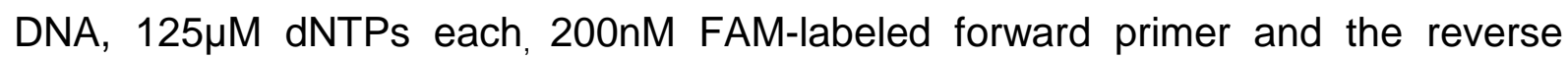
primer and $1 U$ Phire polymerase (Finnzymes, Espoo, Finland). The amplicons were separated using size electrophoresis on the ABI 3730 XL DNA Analyzer (Applied Biosystems, Foster City, USA). For this, samples were diluted $1: 50$ with $0.3 \mathrm{mM}$ EDTA and $4 \mu \mathrm{l}$ were mixed with $6 \mu \mathrm{l}$ LIZ-500 Size Standard (Applied Biosystems). Raw data were processed using the Gene Mapper Software 4.0 (Applied Biosystems).

\subsection{Analysis of PBMCs}

Blood was collected in CPDA tubes from schizophrenic patients with different genotypes in the promoter region of EPO/EPOR. PBMCs were isolated applying the standard Ficoll-Paque Plus isolation procedure (GE Healthcare, München, Germany). RNA was prepared using Qiagen miRNeasy Mini Kit (Qiagen, Hilden, Germany). The RNA samples were used to synthesize cDNAs (SuperScriptIII, Invitrogen, Karlsruhe, Germany). The qRT-PCR was performed with the aid of SYBR Green detection on the LightCycler ${ }^{\circledR} 480$ system (Roche). CT (cycle threshold) values were standardized to $C T$ values of GAPDH.

hEPO_qRT-PCR forward: $\quad$ 5'- TCCCAGACACCAAAGTTAATTTCTA-3'

hEPO_qRT-PCR reverse: 5' CCCTGCCAGACTTCTACGG-3' 
hEPOR_qRT-PCR forward: $\quad$ 5'- TTGGAGGACTTGGTGTGTTTC -3'

hEPOR_qRT-PCR reverse: 5'- AGCTTCCATGGCTCATCCT -3'

hGAPDH_qRT-PCR forward: 5'- CTGACTTCAACAGCGACACC -3'

hGAPDH_qRT-PCR reverse: 5'- TGCTGTAGCCAAATTCGTTGT -3'

\subsection{Statistics}

For all statistical analyses of the data, SPSS for Windows version 17.0 ("SPSS Inc.") was used. For case control comparison, allelic distribution for both EPO SNPs and the possible genotype combinations were tested via $\chi^{2}$-test. Comparisons between cases and controls concerning EPOR STR $(\mathrm{GA})_{n}$ were made via $\chi^{2}$-test of the allelic sum of repeat lengths and separately of the allelic difference between repeat lengths (as a measure of allelic heterogeneity). For testing the influence of genetic markers on cognition, target and control variables had to be Blom transformed (Blom, 1958) since they were not normally distributed. Blom transformed values for speed of processing and verbal learning and memory were used to build a composite score by taking the mean value. Non-native German speakers $(n=89)$ were excluded for all analyses of tests where speech ability may influence the result (verbal learning and memory, premorbid intelligence). Analyses of covariance for target and control variables were carried out, adjusting for age, medication, duration of disease and negative symptoms (measured with PANSS). Independent measures were EPO SNP rs1617640, split up in three groups (TT, TG and GG) and EPOR STR(GA)n, split up in two groups (high vs. low sum of repeat lengths). Covariates for control variables: For the cognitive control variable premorbid intelligence, and for GAF as diseaserelated control variable, analyses of covariance with the same covariates as the target variables were performed. For number of siblings as disease-unrelated control variable, only age was used as covariate. Prior to all phenotype-genotype analyses, gender distribution was controlled using $\chi^{2}$-tests. For assessing the effect of EPO and EPOR genotypes on impulsivity, analyses of covariance with age, duration of disease and medication as covariates were used. To test the effect of the genetic markers on mean values of hemoglobin, hematocrit, erythrocytes, and thrombocytes, analyses of variance as well as student's $t$-tests were carried out for a subsample of 
the GRAS patients ( $n=92-94)$. Due to small sample sizes, impact of EPO and EPOR genotypes on mRNA levels had to be tested non-parametrically using Kruskal-Wallis tests and Mann-Whitney-U tests in the subsample of patients of whom PBMCs were available $(n=35)$. 


\section{Results}

This chapter summarizes the results of statistical analyses, in the order of assembled hypotheses, starting with the case-control study (5.1). This is followed by the PGAS approach on cognitive target variables (5.2) as well as on control variables (5.3), further analyses of STR(GA) (5.4), the influence of genetic markers on blood levels (5.5), effects on impulsivity (5.7), as well as on mRNA levels (5.8).

\subsection{Genetic analyses}

For the case-control study, the allelic distribution of both EPO SNPs, did not yield any differences between the groups (rs1617640: $\chi^{2}=.019, p=.890$; rs564449: $\chi^{2}=.002, p=.964$ ), both markers fulfilled the Hardy-Weinberg equilibrium criteria. Also, when the distribution of genotypes (GG, GT, TT) for both SNPs were compared, no group differences were found between cases and controls (rs1617640: $\chi^{2}=1.099$, $\mathrm{p}=.580$; rs564449: $\chi^{2}=.035, \mathrm{p}>.999$; see Figures 3 and 4).

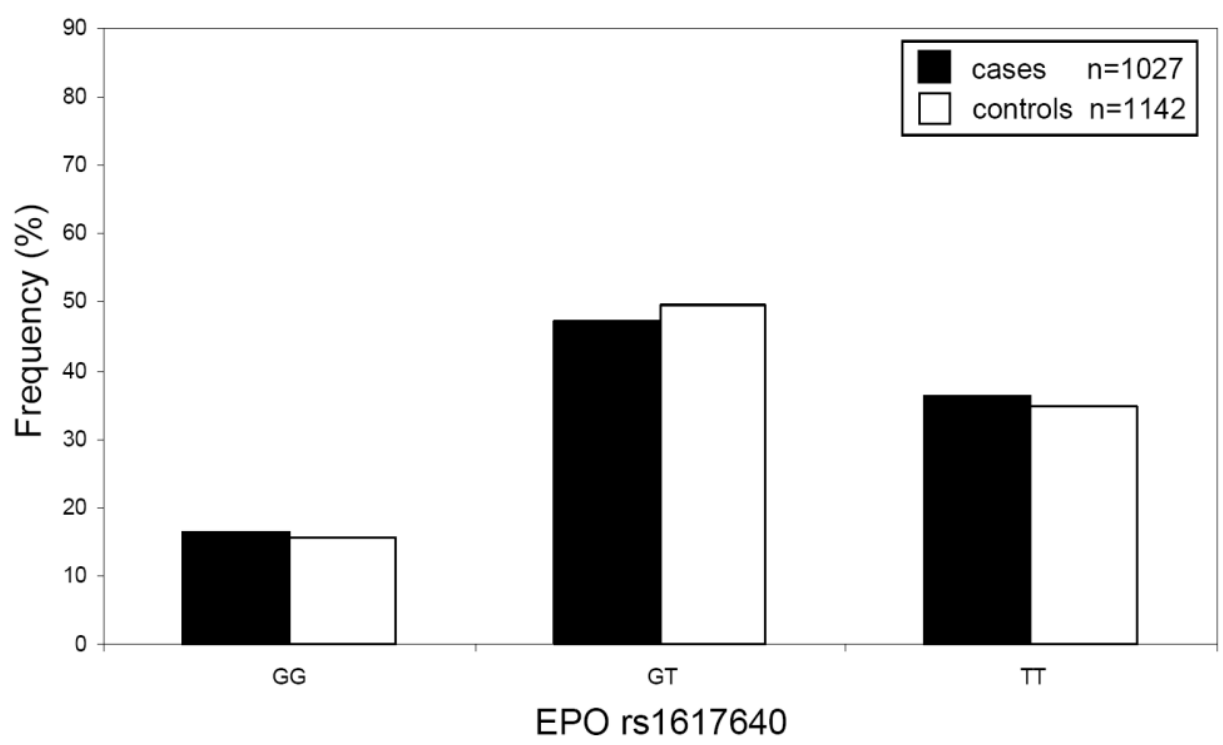

Figure 5: Distribution of genotypes for SNP rs1617640 of EPO gene 


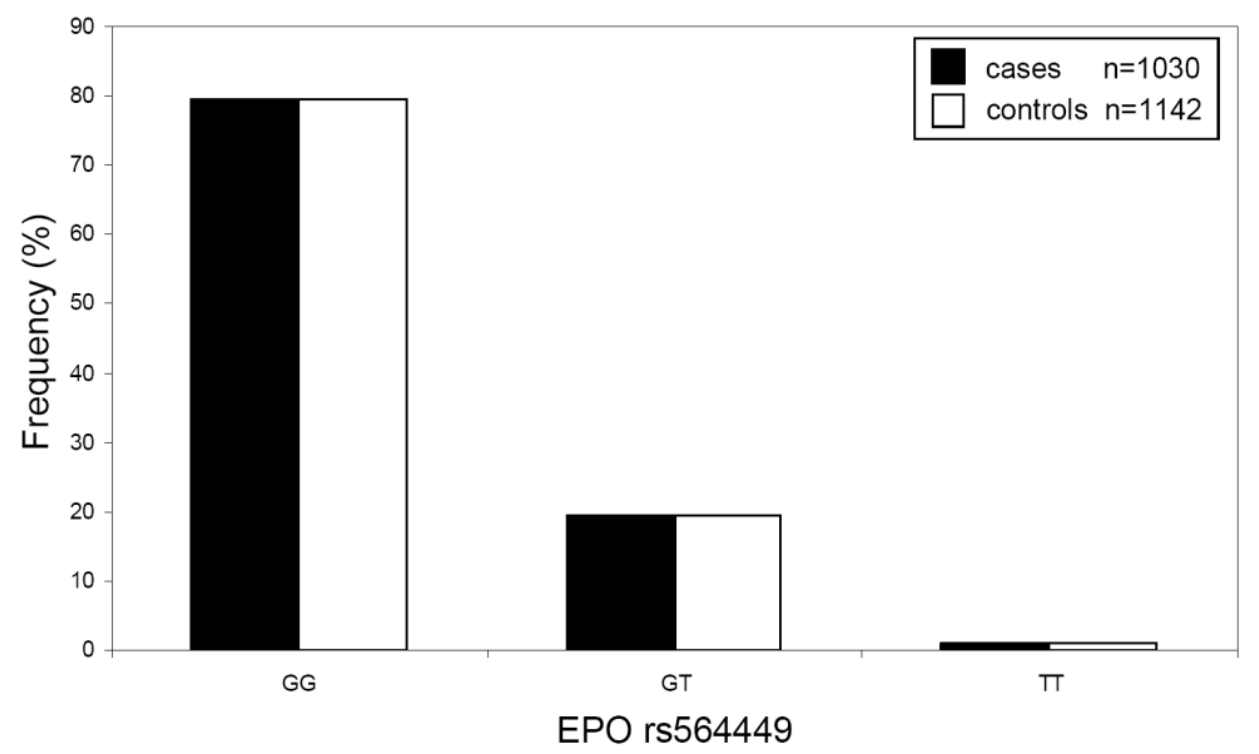

Figure 6: Distribution of genotypes for SNP rs564449 of EPO gene

Additional analyses exclusively with patients who fulfilled criteria for classical schizophrenia $(n=852)$ did not yield different results ( $r$ 1617640: $\chi^{2}=1.204, p=.548$; rs564449: $\left.\chi^{2}=.130, p=.937\right)$. Since the allelic frequency of rs564449 was not well distributed (TT genotype only in $1 \%$ of the cases), this SNP was excluded from further analyses.

For comparison of the EPOR marker STR $(\mathrm{GA})_{n}$, sum of allelic repeat lengths (Sum, Figure 7) as well as difference between allelic repeat lengths (Difference, Figure 8) were compared between cases and controls and did not show any differences (Sum: $\chi^{2}=24.817, p=.846$; Difference: $\chi^{2}=7.091, p=.982$ ). 


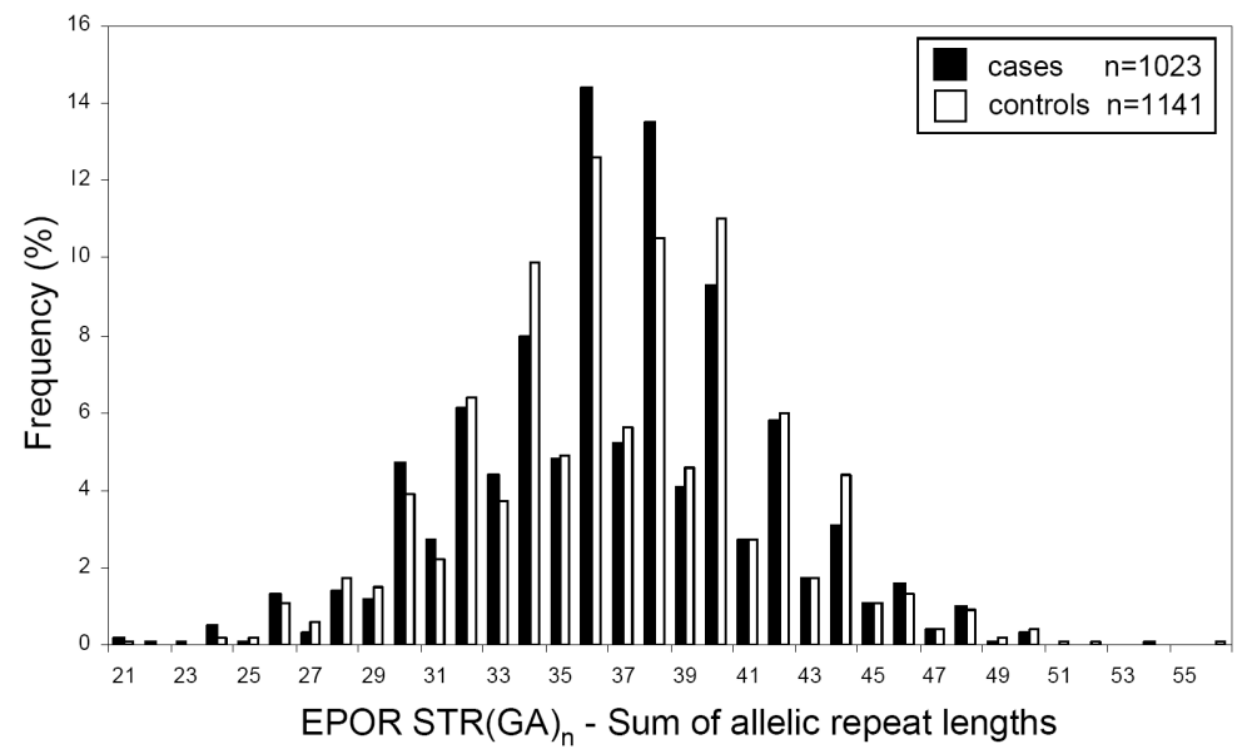

Figure 7: Distribution of sum of allelic repeat lengths of EPOR STR among cases and controls

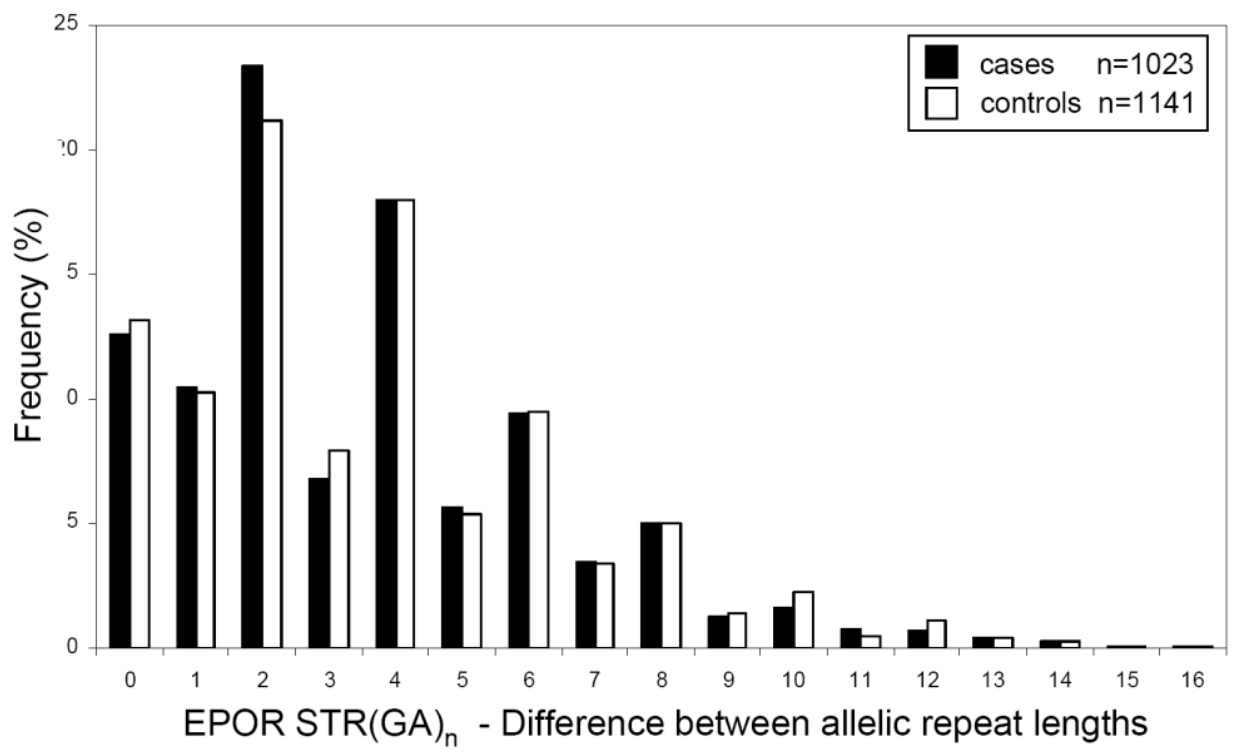

Figure 8: Distribution of difference between allelic repeat lengths of EPOR STR among cases and controls

As in the case of both EPO markers, these results hold true even upon restriction of analyses to the subsample of GRAS patients who carry the diagnosis of classical schizophrenia (Sum: $\chi^{2}=26.143, p=.796$; Difference: $\chi^{2}=10.003, p=.903$ ). 


\subsection{PGAS approach}

Before testing for genotype-phenotype associations, distribution of gender was analysed and there was no significant difference between genetic groups (EPO rs 1617640: $\chi^{2}=1.623, p=.448$; EPOR STR $\left.(\mathrm{GA})_{n}: \chi^{2}=.070, p=.842\right)$. Thus, no further correction for gender was needed.

As shown in Table 5, raw data of the cognitive tests as well as the Blom-transformed but still uncorrected data for the cognitive composite score give already a hint for the direction of possible genetic effects. For premorbid intelligence, speed of processing, verbal learning and memory, and the cognitive composite score, GG genotypes of EPO SNP reached higher test values, reflecting superior cognitive performance than GT and TT genotypes, whilst patients with low sum of repeat lengths in EPOR marker yielded better values in premorbid intelligence, verbal learning and memory and on the cognitive composite score than patients with high sum of repeat lenghts. Still, compared to the healthy normative population provided from each test manual (Helmstaedter, et al., 2001; Lehrl, Triebig, \& Fischer, 1995; Tewes, 1991), mean performance of the GRAS patients on speed of processing and verbal learning and memory lies in the lower normal range ( $P R=16$ for $Z S T$ ) or even below it ( $P R=10$ for VLMT 1-5). Only results for premorbid intelligence fell in the mean range of the healthy normative population (PR=42).

Table 5: Obtained raw data of EPO and EPOR genotype groups in cognitive tests, including percentile rank in relation to normative sample

\begin{tabular}{|c|c|c|c|c|c|c|}
\hline & \multicolumn{3}{|c|}{$\begin{array}{l}\text { EPO } \\
\text { rs1617640 }\end{array}$} & \multicolumn{2}{|c|}{$\begin{array}{c}\text { EPOR } \\
\operatorname{STR}(G A)_{n}{ }^{1}\end{array}$} & \multirow{2}{*}{$\begin{array}{c}\text { Percentile } \\
\text { Rank }\end{array}$} \\
\hline & GG & GT & TT & $\begin{array}{l}\text { low } \\
\text { sum }\end{array}$ & $\begin{array}{l}\text { high } \\
\text { sum }\end{array}$ & \\
\hline Cognitive - Composite Score ${ }^{2}$ & $\begin{array}{r}0.13 \\
\pm 0.94\end{array}$ & $\begin{array}{r}0.03 \\
\pm 0.85\end{array}$ & $\begin{array}{l}-0.06 \\
\pm 0.87\end{array}$ & $\begin{array}{l}0.04 \\
\pm 0.87\end{array}$ & $\begin{array}{l}-0.02 \\
\pm 0.89\end{array}$ & - \\
\hline $\begin{array}{l}\text { Speed of Processing } \\
(\mathrm{ZST})\end{array}$ & $\begin{array}{r}40.12 \\
\pm 14.22\end{array}$ & $\begin{array}{r}37.57 \\
\pm 12.57\end{array}$ & $\begin{array}{l}36.97 \\
\pm 13.10\end{array}$ & $\begin{array}{r}37.91 \\
\pm 13.05\end{array}$ & $\begin{array}{l}37.67 \\
\pm 13.24\end{array}$ & PR 16 \\
\hline $\begin{array}{l}\text { Verbal Learning and Memory }{ }^{2} \\
\text { (VLMT 1-5) }\end{array}$ & $\begin{array}{r}42.64 \\
\pm 13.20\end{array}$ & $\begin{array}{r}42.22 \\
\pm 12.75\end{array}$ & $\begin{array}{r}40.39 \\
\pm 12.54\end{array}$ & $\begin{array}{r}42.28 \\
\pm 12.91\end{array}$ & $\begin{array}{r}40.90 \\
\pm 12.66\end{array}$ & PR 10 \\
\hline $\begin{array}{l}\text { Premorbid Intelligence }{ }^{2} \\
\text { (MWTB) }\end{array}$ & $\begin{array}{l}26.53 \\
\pm 5.93\end{array}$ & $\begin{array}{l}26.08 \\
\pm 6.22\end{array}$ & $\begin{array}{l}25.67 \\
\pm 6.30\end{array}$ & $\begin{array}{l}26.23 \\
\pm 6.09\end{array}$ & $\begin{array}{l}25.76 \\
\pm 6.32\end{array}$ & PR 42 \\
\hline
\end{tabular}


Analyses of covariance correcting for age, duration of disease, medication and negative symptoms yielded significant differences between genetic groups concerning the target variables. Table 3 gives an overview of all results on the cognitive composite score, the single target variables as well as the control variables.

Table 6: Associations of EPO SNP and EPOR STR with target and control variables $(n=841-945)$

\begin{tabular}{|c|c|c|c|}
\hline & $\begin{array}{c}\text { EPO } \\
\text { rs1617640 }\end{array}$ & $\begin{array}{c}\text { EPOR } \\
\text { STR }(\mathrm{GA})_{n}{ }^{1}\end{array}$ & $\begin{array}{l}\text { Interaction } \\
\text { EPOXEPOR }\end{array}$ \\
\hline & $\begin{array}{c}F \\
(p)\end{array}$ & $\begin{array}{c}F \\
(p)\end{array}$ & $\begin{array}{c}F \\
(p)\end{array}$ \\
\hline \multicolumn{4}{|l|}{ Target Variables } \\
\hline \multicolumn{4}{|l|}{ Combined } \\
\hline Cognitive Composite Score ${ }^{2}$ & $\begin{array}{l}3.708 \\
(.025)\end{array}$ & $\begin{array}{l}5.997 \\
(.015)\end{array}$ & $\begin{array}{l}4.101 \\
(.017)\end{array}$ \\
\hline \multicolumn{4}{|l|}{ Single Targets } \\
\hline Speed of Processing (ZST) & $\begin{array}{l}5.230 \\
(.006)\end{array}$ & $\begin{array}{l}2.226 \\
(.136)\end{array}$ & $\begin{array}{l}1.579 \\
(.207)\end{array}$ \\
\hline Verbal Learning and Memory (VLMT 1-5) & $\begin{array}{l}2.511 \\
(.082)\end{array}$ & $\begin{array}{l}6.210 \\
(.013)\end{array}$ & $\begin{array}{l}4.327 \\
(.014)\end{array}$ \\
\hline \multicolumn{4}{|l|}{ Control Variables } \\
\hline \multicolumn{4}{|l|}{ Cognitive Control Variable } \\
\hline Premorbid Intelligence (MWTB) ${ }^{2}$ & $\begin{array}{c}.735 \\
(.480)\end{array}$ & $\begin{array}{l}2.567 \\
(.109)\end{array}$ & $\begin{array}{l}.608 \\
(.498)\end{array}$ \\
\hline \multicolumn{4}{|l|}{ Disease-related Control Variable } \\
\hline Global Assessment of Functioning (GAF) & $\begin{array}{l}.271 \\
(.762)\end{array}$ & $\begin{array}{l}2.804 \\
(.094)\end{array}$ & $\begin{array}{c}.520 \\
(.594)\end{array}$ \\
\hline \multicolumn{4}{|l|}{ Disease-unrelated Control Variable } \\
\hline Number of Siblings & $\begin{array}{l}2.052 \\
(.129)\end{array}$ & $\begin{array}{l}1.202 \\
(.273)\end{array}$ & $\begin{array}{c}.255 \\
(.775)\end{array}$ \\
\hline
\end{tabular}

'EPOR repeat lengths sum (split into 2 groups [21-36] \& [37-54])

${ }^{2}$ for all analyses with speech-dependent readouts, non-German speakers were excluded 
For the cognitive composite score, main effects of the EPO SNP rs1617640 and of EPOR STR $(G A)_{n}$ were found (rs1617640: $F_{2,847}=3.708, \quad p=.025 ; \operatorname{STR}(G A)_{n}$ : $\left.F_{1,843}=5.997, p=.015\right)$. Bonferroni corrected post-hoc comparison for the three groups of EPO rs1617640 showing a significant difference between T-homozygotes and Ghomozygotes $(p=.016)$, with $G$-homozygotes having much better results in the cognitive composite score than T-homozygotes, whilst the heterozygotes lie in between both groups (Figure 9). For EPOR STR $(G A)_{n}$, low sums of repeat lengths yielded significantly better results than high sums of repeat lengths (Figure 9).
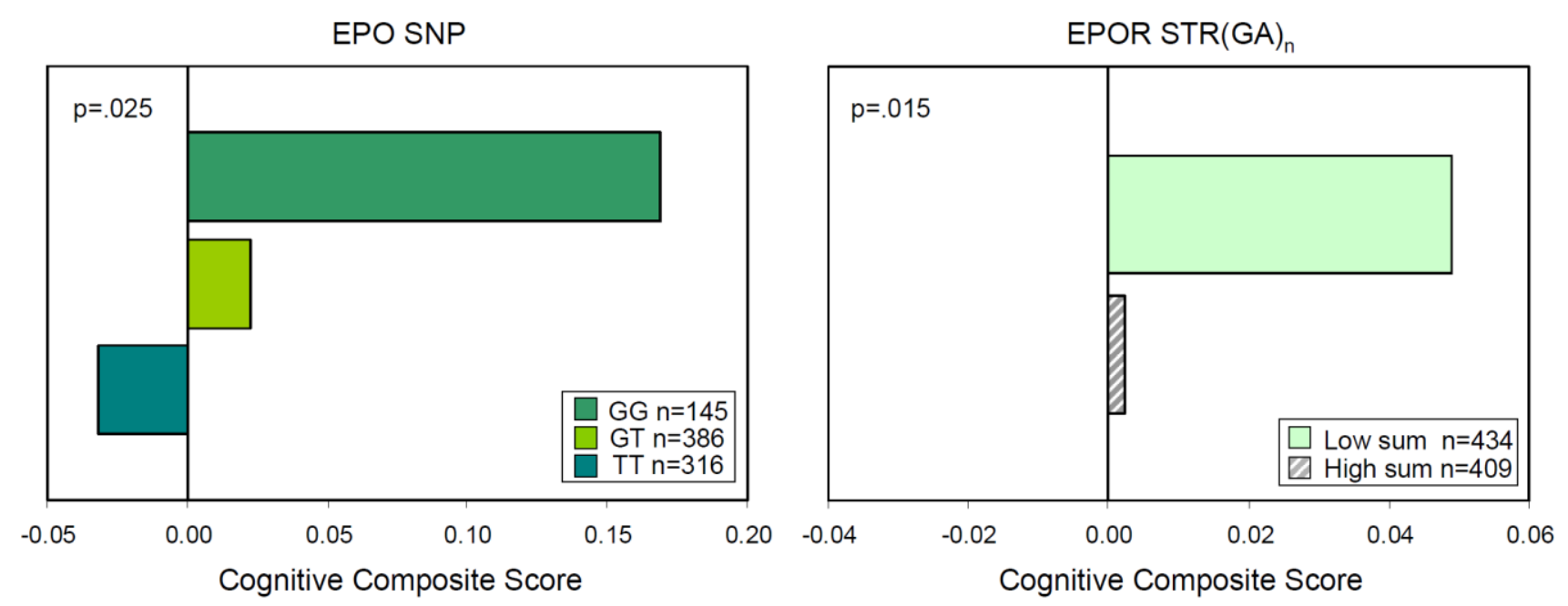

Figure 9: Main effects of EPO SNP and EPOR STR on Cognitive Composite Score

Also, an additional analysis of covariance revealed an interaction effect of both markers concerning the cognitive composite score $\left(\mathrm{F}_{2,841}=4.101, \mathrm{p}=.017\right)$, as displayed in Figure 10. GG homozygotes in EPO SNP with a low sum of allelic repeat lengths in EPOR repeat are much better than all other groups, whilst GG homozygotes with a high sum of allelic repeat lengths are much worse. For the heterozygotes in EPO SNP, effect of EPOR repeat goes in the opposite direction: a high sum of allelic repeat lengths is associated with a better performance in cognitive composite score, and a low sum of allelic repeat lengths is associated with a worse performance. 


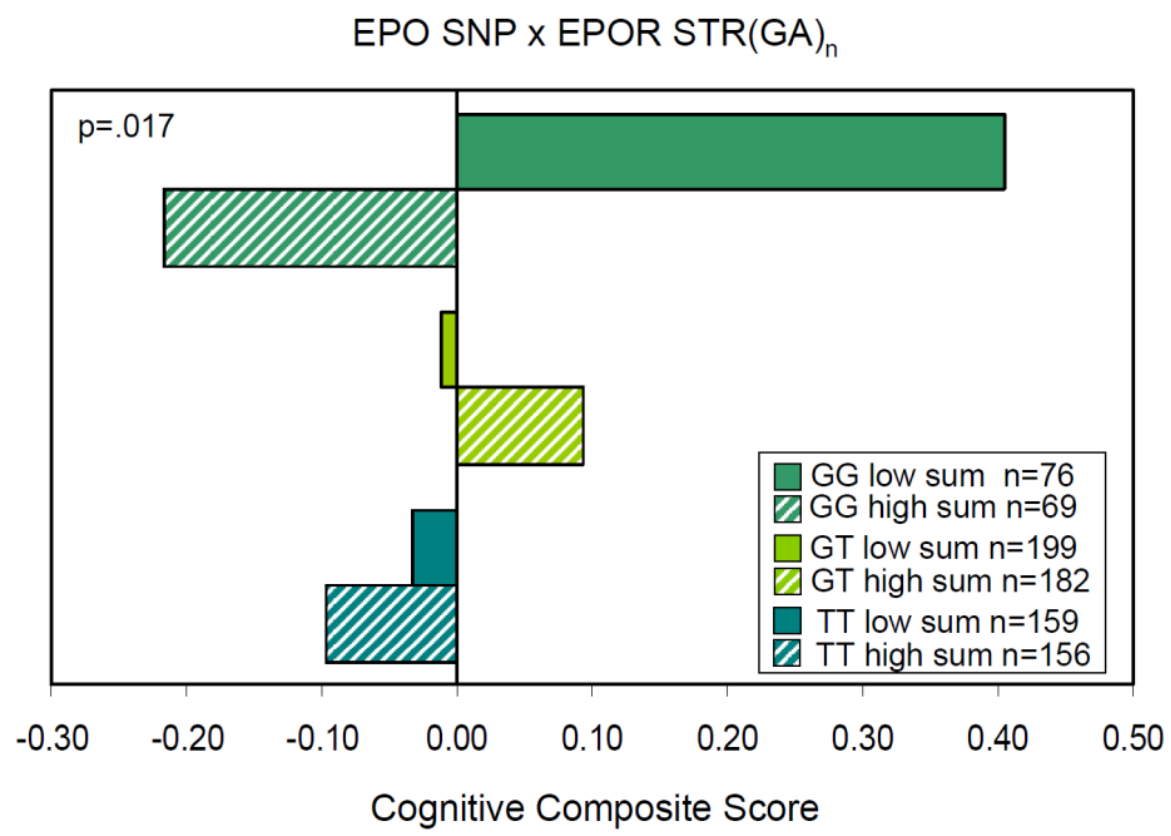

Figure 10: Display of the interaction effect of both genetic markers on Cognitive Composite Score

For speed of processing as single target variable, EPO SNP rs 1617640 yielded significant differences between groups $\left(\mathrm{F}_{2,945}=5.230, \mathrm{p}=.006\right)$. Post-hoc analyses showed a significant difference between T-homozygotes and G-homozygotes even after Bonferroni correction ( $p=.004)$ as well as a difference between $G$-homozygotes and the heterozygous group ( $p=.024)$. Again, $G$-homozygotes have better results in speed of processing than T-homozygotes, whilst the heterozygotes lie in between both groups (Figure 11).
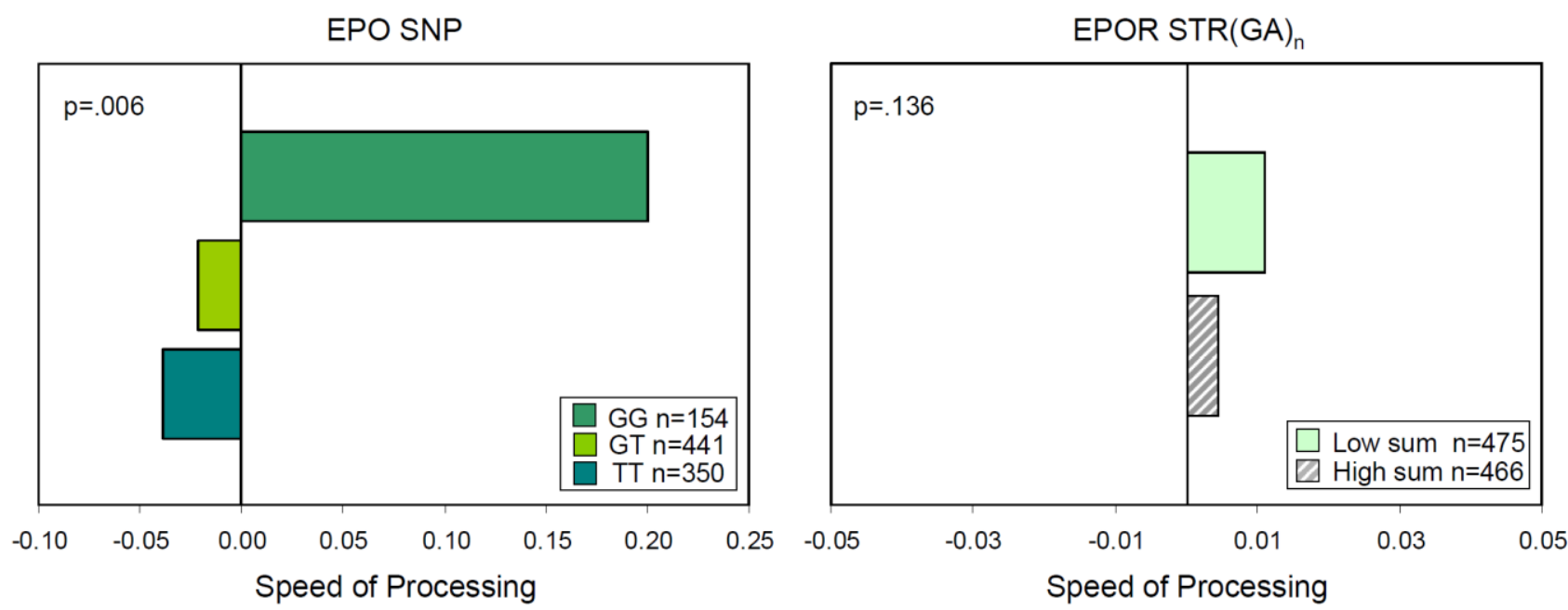

Figure 11: Influence of EPO SNP and EPOR STR on Speed of Processing 
The EPOR STR did not have a significant effect on speed of processing (also Figure 11), neither did the two markers significantly interact on this cognitive domain (Figure 12). Even though it does not reach the significance level at all, the interaction pattern of both markers together on that domain looks very similar compared to the pattern found on the cognitive composite score.

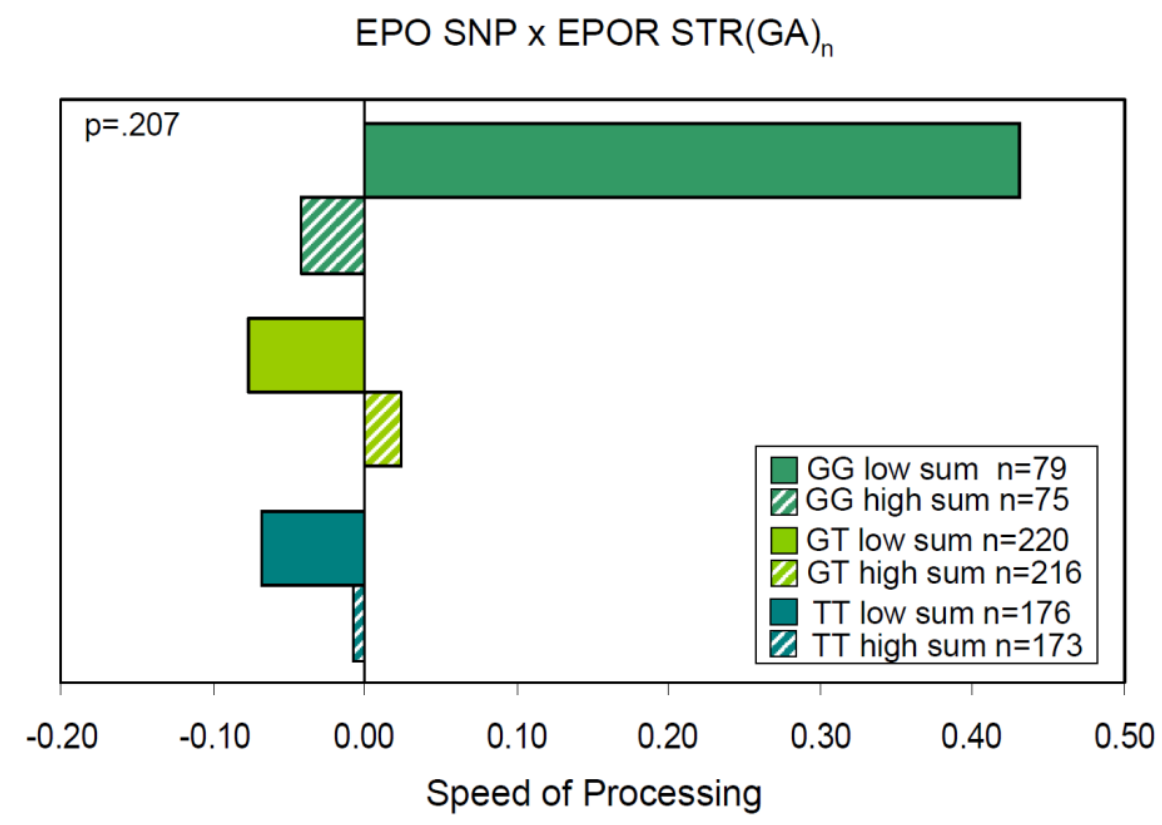

Figure 12: Interaction effect of EPO SNP and EPOR STR on Speed of Processing

EPOR STR $(G A)_{n}$ on the other hand seems to have more influence on verbal learning and memory as single target variable $\left(\mathrm{F}_{1,846}=6.210, \mathrm{p}=.013\right)$. Patients having a low sum of repeat length learning the word list better than patients with a high sum of repeat length (Figure 13). Results for EPO SNP rs1617640 are close to significance $\left(F_{1,850}=2.511, p=.082\right)$, again with $G G$ genotypes yielding the best results and TT genotypes the worst. 

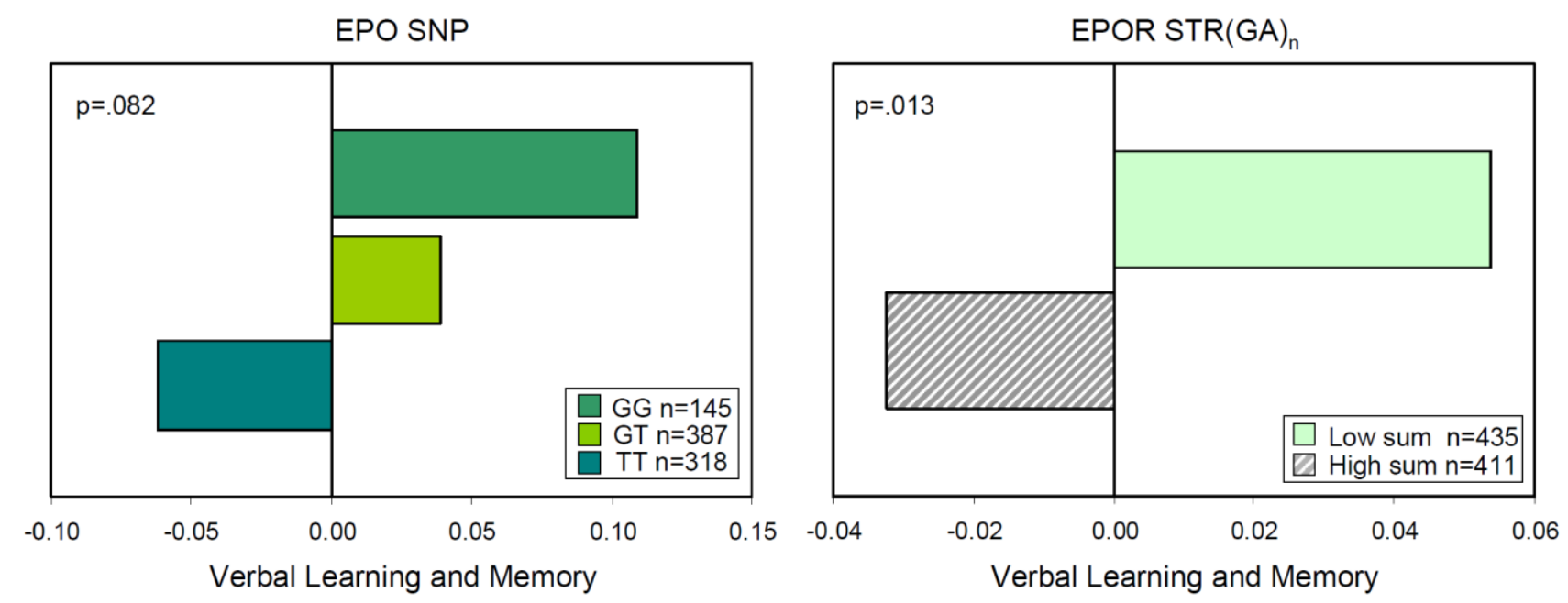

Figure 13: Main effects of EPO and EPOR markers on Verbal Learning and Memory

Also, an interaction effect between both genetic markers and the verbal learning and memory task was detected $\left(\mathrm{F}_{2,844}=4.327, \mathrm{p}=.014\right)$, illustrating the same interaction pattern as in the composite score (Figure 14).

EPO SNP $\times$ EPOR STR $(G A)_{n}$

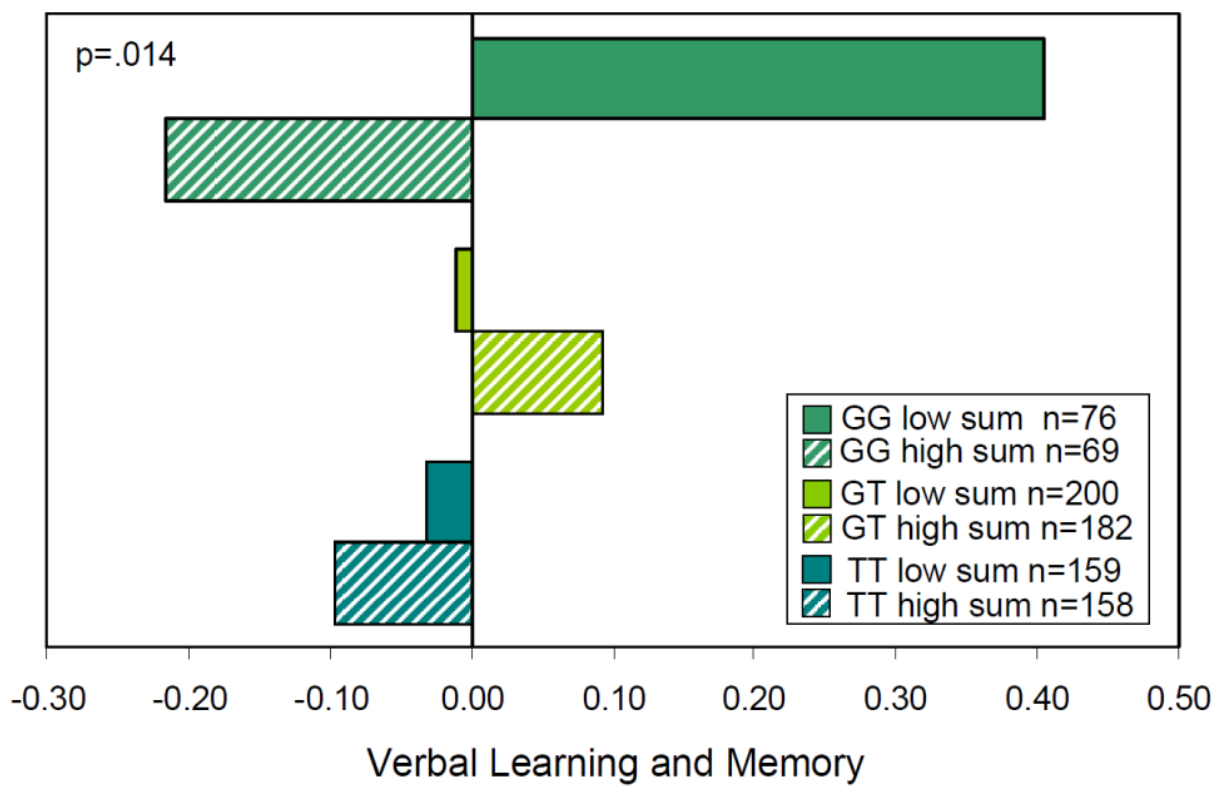

Figure 14: Interaction effect of EPO and EPOR on Verbal Learning and Memory 


\subsection{Control variables}

EPO SNP and EPOR STR each had no effect on the control variables, neither on the cognitive control variable premorbid intelligence, nor on the disease-related control variable global assessment of functioning or the disease-unrelated control variable number of siblings. Also no interaction effect of the genetic markers on the control variables was found. Table 5 summarizes the presented results.

\subsection{Further analyses of STR(GA)}

It was an attempt to analyse the EPOR marker split up in high and low allelic sum of repeat lengths. This decision was made in order to not allow the number of subjects per group get too small to lose all statistical power. To discover what may lie behind the pattern of different allelic sum of repeat lengths, the EPOR genotype effect on the cognitive target variables was further explored.

\subsubsection{Sum of allelic repeat lengths}

One attempt was to split up the sum of allelic repeat lengths in four rather than in two groups. Significant main effects of EPOR on the cognitive composite score $\left(F_{3,843}=3.896, p=.009\right.$; Figure 16$)$ and on verbal learning and memory $\left(F_{3,846}=3.706\right.$, $\mathrm{p}=.011)$ were found but not on speed of processing $\left(F_{3,941}=1.692, p=.167\right.$; Figure 15).
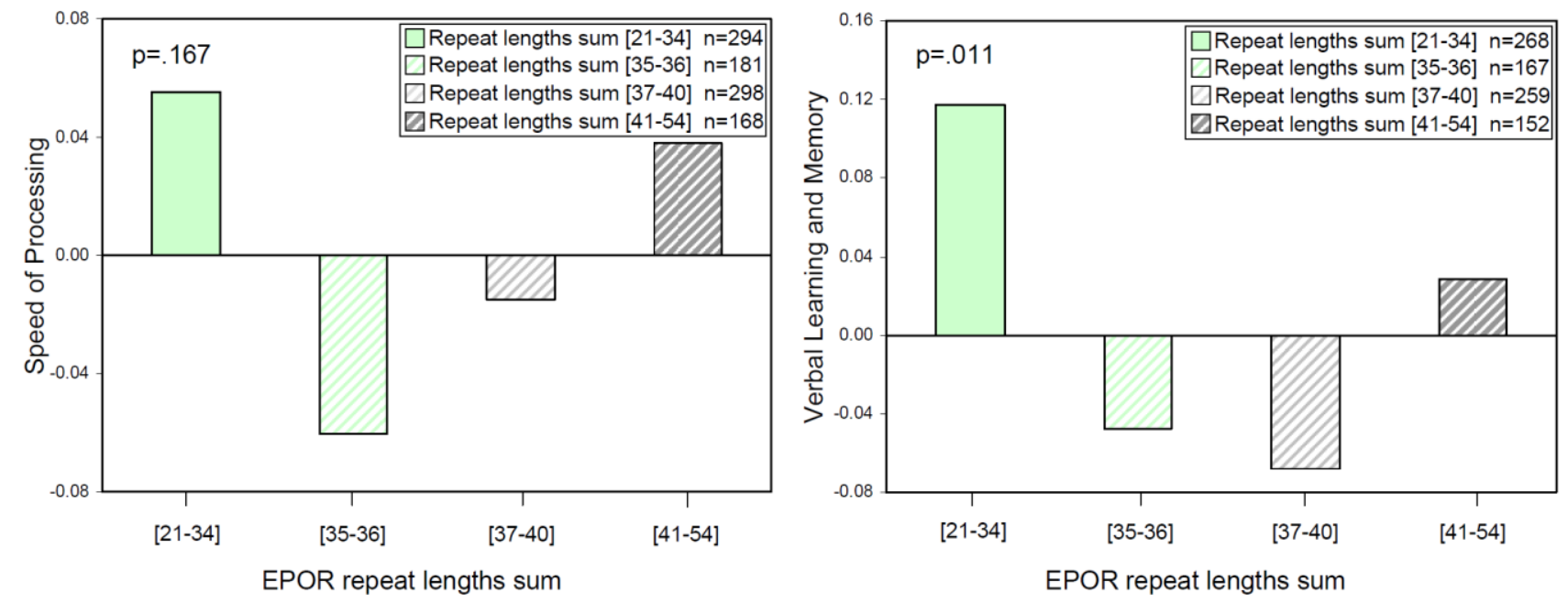

Figure 15: Effect of EPOR STR split up in four repeat length sum groups on Speed of Processing and Verbal Learning and Memory 


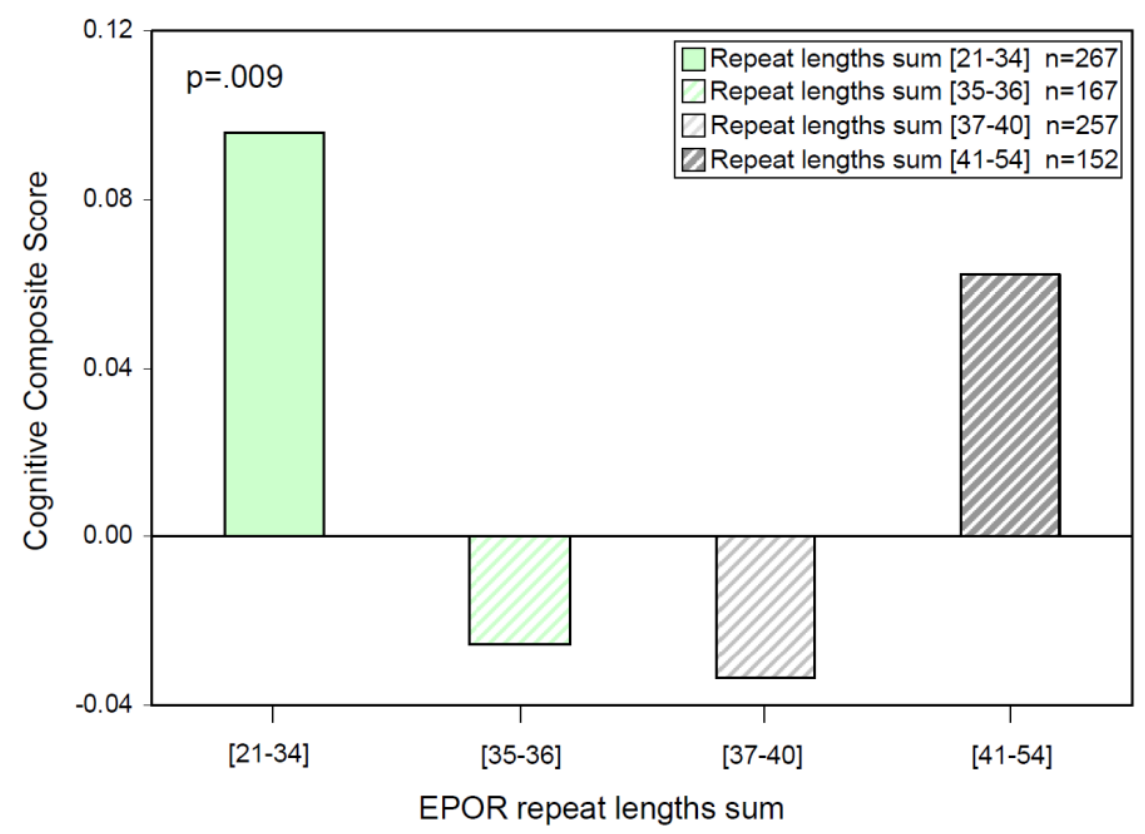

Figure 16: Effect of EPOR four sum groups on the Cognitive Composite Score

Post-hoc analyses revealed that in cases of cognitive composite score (Figure 16) and verbal learning and memory, significant effects after Bonferroni correction remain between group 1 (lowest sums of repeat length, 21-34) and group 3 (second to highest sums of repeat length, 37-40) with $p=.006$ for cognitive composite score and $\mathrm{p}=.008$ for verbal learning and memory, with group 1 showing the best test results of all groups and group 3 showing the worst ones.

However, statistical power gets too low by splitting up in four EPOR sum groups to reveal a significant interaction effect with the EPO SNP rs1617640 (composite score: $F_{6,841}=1.753, p=.106$; speed of processing: $F_{6,939}=.790, p=.578$; verbal learning and memory: $F_{6,844}=1.844, p=.088$ ). But the graphical demonstration of this analysis gives a clue for how the interaction between the three EPO rs1617640 genotype groups (GG, GT, TT) and the four EPOR sum groups is taking place (see Figure 17; data shown in relation to the best performing group with GG genotype in EPO SNP and shortest sum of repeat lengths in EPOR STR [21-34]). With a larger number of subjects, even further partitioning of the EPOR groups might be useful. 

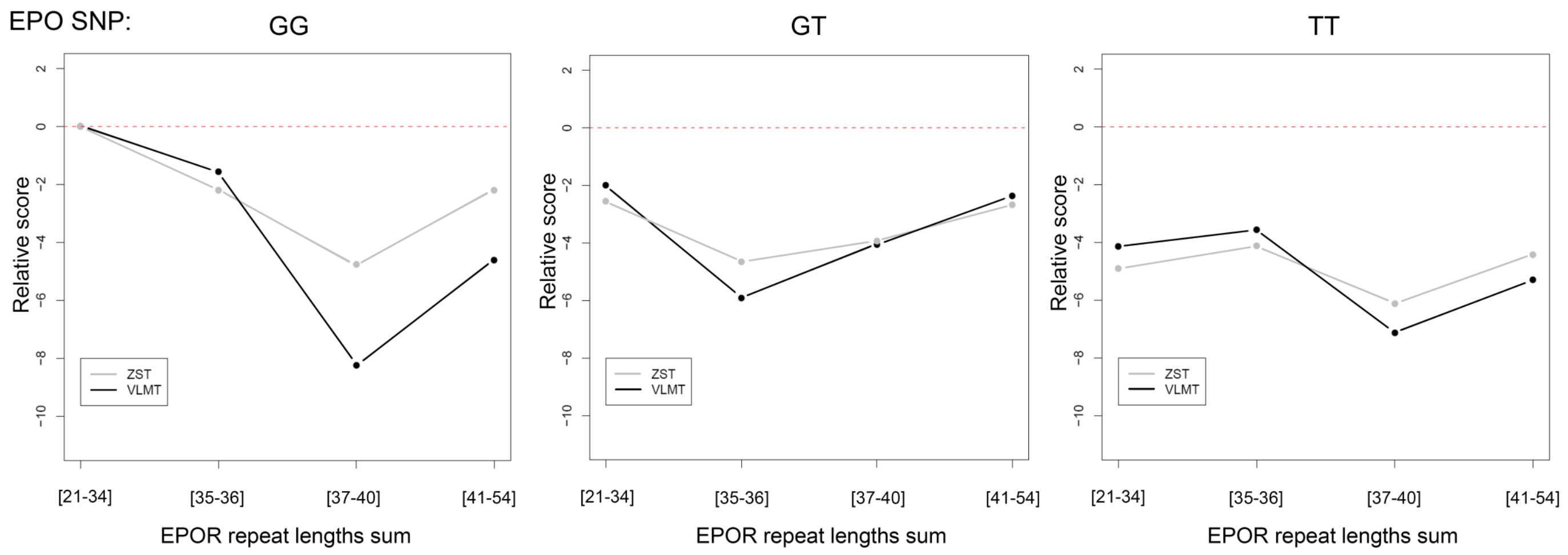

Figure 17: Interaction of the three EPO SNP genotype groups with four EPOR repeat lengths sum groups 


\subsubsection{Heterogeneity of allelic repeat lengths}

The difference between allelic repeat lengths (as a measure for the heterogeneity of alleles) differed significantly between the four EPOR sum of allelic repeat lengths groups $\left(F_{3,1022}=13.506, p<.001\right)$. Bonferroni corrected post-hoc tests revealed that significant effects can be found between the first [21-34] and second [35-36] group $(p<.001)$, between the first and third [37-40] group $(p<.001)$, between the second and fourth [41-54] group $(p=.005)$, and between the third and fourth group of EPOR allelic repeat lengths sum $(p=.002)$.

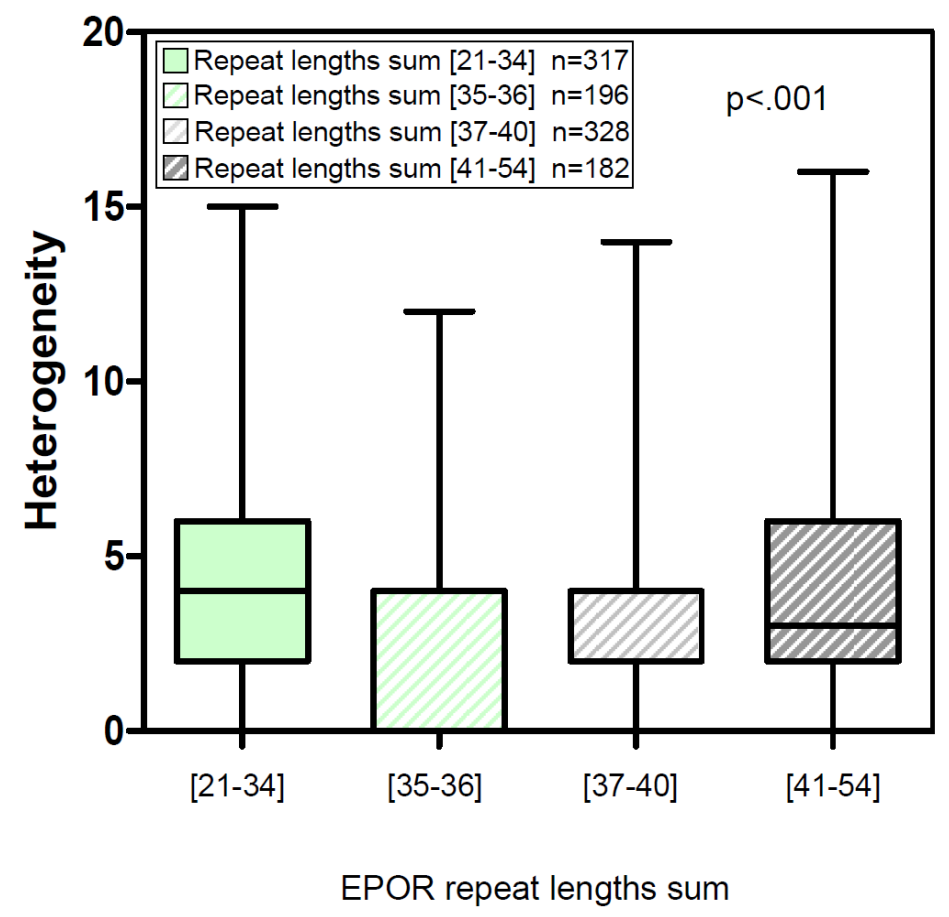

Figure 18: Heterogeneity of the four EPOR repeat lengths groups

\subsection{Exploration of genetic influence on blood levels}

In the subsample of GRAS patients from whom blood values were available ( $n=92-$ 94), gender distribution was checked and showed no differences between genotype groups (EPO rs1617640: $\chi^{2}=.532, p=.787$; EPOR STR $(G A)_{n}: \chi^{2}=.038, p>.999$ ). No effect was found for neither genetic marker on levels of hemoglobin (EPO rs1617640: $\mathrm{F}_{2,94}=.063, \mathrm{p}=.939$; EPOR STR(GA) $)_{n} t=.256, \mathrm{df}=92, \mathrm{p}=.799$ ), hematocrit (EPO rs1617640: $\left.F_{2,94=.146,} \mathrm{p}=.864 ; \quad \operatorname{EPOR} \quad \operatorname{STR}(\mathrm{GA})_{\mathrm{n}}: \quad t=.569, \mathrm{df}=92, \mathrm{p}=.571\right)$, erythrocytes (EPO rs1617640: $\mathrm{F}_{2,94}=.223, \mathrm{p}=.800$; EPOR STR(GA) $: t=.394, \mathrm{df}=92$, $\mathrm{p}=.695$ ) or thrombocytes (EPO rs1617640: $F_{2,94}=1.261, p=.288$; EPOR STR(GA)n: 
$t=.201, \mathrm{df}=92, \mathrm{p}=.841)$. Table 7 demonstrates the equal distribution of blood values among genotypes. A further subdivision of EPOR STR $(\mathrm{GA})_{\mathrm{n}}$ sum of allelic repeat lengths in four groups did not yield different results.

Table 7: Mean values and standard deviations for blood indices per genotype group

\begin{tabular}{|c|c|c|c|c|c|}
\hline & \multicolumn{3}{|c|}{ EPO rs1617640 } & \multicolumn{2}{|c|}{ EPOR STR(GA)n } \\
\hline & $\begin{array}{c}\text { GG } \\
n=13\end{array}$ & $\begin{array}{c}\text { GT } \\
n=46\end{array}$ & $\begin{array}{c}\text { TT } \\
n=35\end{array}$ & $\begin{array}{l}\text { low } \\
\text { sum } \\
n=50\end{array}$ & $\begin{array}{l}\text { high } \\
\text { sum } \\
\mathrm{n}=42\end{array}$ \\
\hline hemoglobin & $\begin{array}{l}14.751 \\
\pm 1.317\end{array}$ & $\begin{array}{c}14.710 \\
\pm 0.930\end{array}$ & $\begin{array}{c}14.650 \\
\pm 1.311\end{array}$ & $\begin{array}{c}14.748 \\
\pm 1.112\end{array}$ & $\begin{array}{c}14.645 \\
\pm 1.181\end{array}$ \\
\hline hematocrit & $\begin{array}{c}43.765 \\
\pm 3.877\end{array}$ & $\begin{array}{c}43.480 \\
\pm 2.625\end{array}$ & $\begin{array}{c}43.264 \\
\pm 3.837\end{array}$ & $\begin{array}{c}43.661 \\
\pm 3.187\end{array}$ & $\begin{array}{c}43.226 \\
\pm 3.453\end{array}$ \\
\hline erythrocytes & $\begin{array}{l}4.860 \\
\pm 0.439\end{array}$ & $\begin{array}{r}4.908 \\
\pm 0.394\end{array}$ & $\begin{array}{l}4.832 \\
\pm 0.481\end{array}$ & $\begin{array}{l}4.894 \\
\pm 0.442\end{array}$ & $\begin{array}{l}4.850 \\
\pm 0.432\end{array}$ \\
\hline thrombocytes & $\begin{array}{c}271.166 \\
\pm 54.047\end{array}$ & $\begin{array}{c}250.669 \\
\pm 42.291\end{array}$ & $\begin{array}{c}271.683 \\
\pm 70.701\end{array}$ & $\begin{array}{c}261.442 \\
\pm 59.959\end{array}$ & $\begin{array}{c}261.870 \\
\pm 52.927\end{array}$ \\
\hline
\end{tabular}

\subsection{Impulsivity in humans}

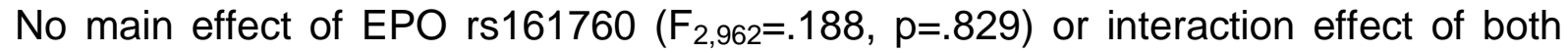
markers together $\left(\mathrm{F}_{2,956}=1.141, \mathrm{p}=.320\right)$ was found on impulsivity, but a significant main effect of EPOR STR(GA)n, when analyzing two groups (high/low: $F_{1,958}=4.804$, $\mathrm{p}=.029$ ) with the low repeat sum group being more impulsive than the high repeat sum group (Figure 19; data shown as mean values + standard error of mean). 


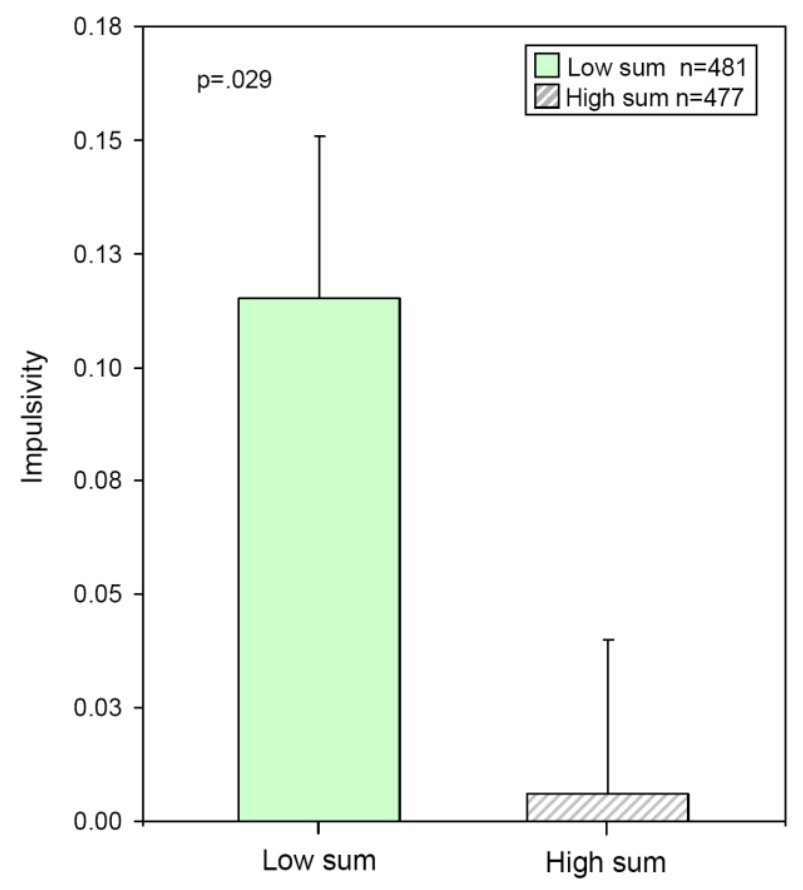

Figure 19: Effect of EPOR repeat separated in high and low sum on impulsivity

By analyzing four groups of EPOR STR $(G A)_{n}$ allelic sum of repeat lengths, results were no longer significant (four groups: $F_{3,958}=1.958, p=.119$ ). Nevertheless, Figure 20 clearly shows that the influence of the EPOR genetic variant $\operatorname{STR}(G A)_{n}$ on impulsivity is on the "same line" as its influence on the cognitive readout (data shown in relation to the best performing group [21-34]). As in the mouse model, humans who reveal the best results on speed of processing and verbal learning and memory tasks, are most impulsive. 


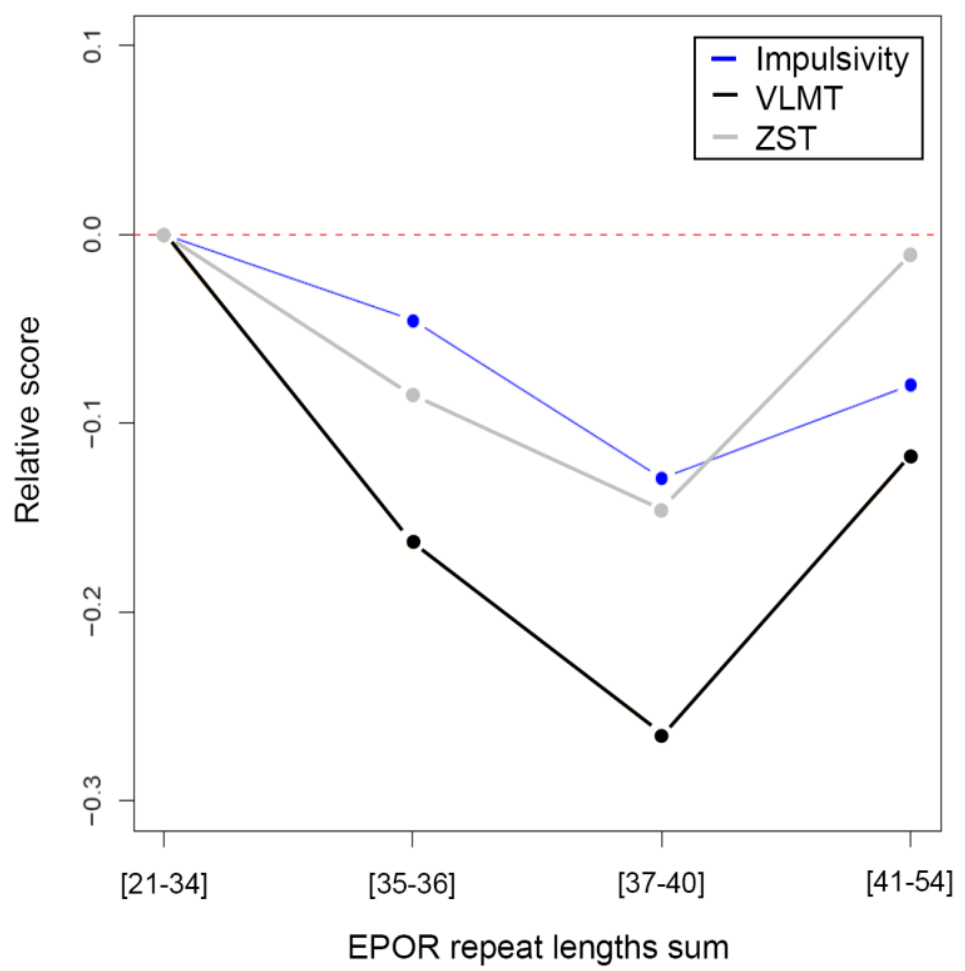

Figure 20: Association of EPOR STR(GA) ${ }_{n}$ with impulsivity

\subsection{Effects of genetic markers on mRNA}

It was tested before, whether gender distributions were different between genotype groups (EPO rs1617640: $\chi^{2}=2.804, p=.268$; EPOR STR $(\mathrm{GA})_{n}: \chi^{2}=.224, \mathrm{p}=.712$ ), but no differences were found.

Genotypes of the analysed markers did not have a significant influence on their own mRNA level in PBMCs (EPO: $\chi^{2}=.350, p=.840$; EPOR: $Z=-.202, p=.855$ ). Interestingly, EPOR STR $(\mathrm{GA})_{n}$ had an influence on the level of EPO mRNA (high/low grouping: $Z=-2.088, p=.037$, with the low repeat sum group having less EPO mRNA concentration in the peripheral blood (Figure 21). 


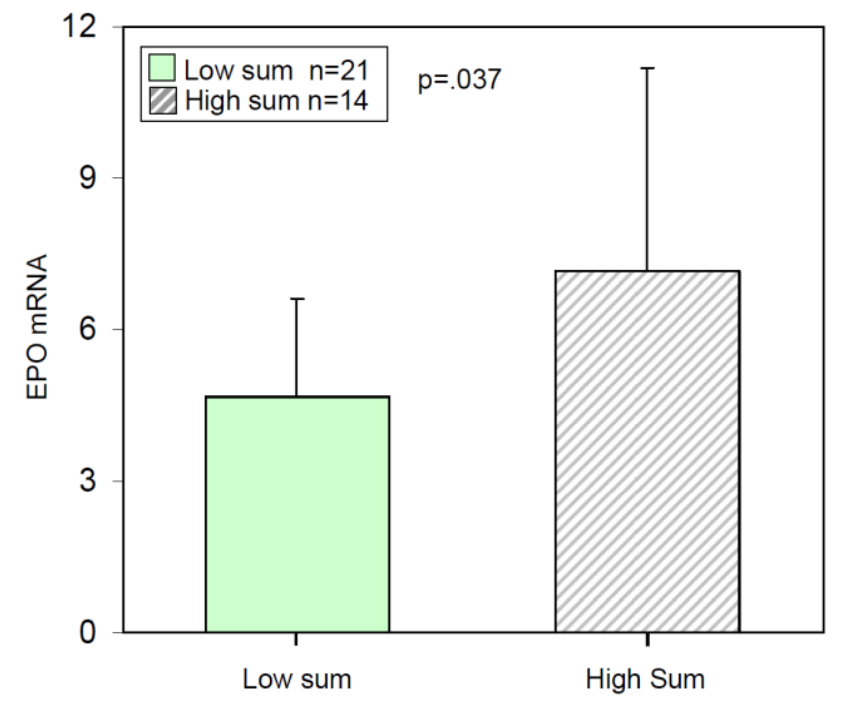

Figure 21: Effect of EPOR repeat separated in high and low sum on EPO mRNA

Concerning the four group approach, an even more interesting finding was revealed as shown in Figure 22: Again, like in the results concerning cognition, the first and third group had the most extreme values. But group one - which was cognitively the best group - has the least EPO mRNA whilst group three - concerning cognition the worst group - has the highest EPO mRNA concentration of the four groups $\left(\chi^{2}=6.767\right.$, $\mathrm{p}=.080$ ). Due to small $\mathrm{n}$ numbers this result does not reach significance level.

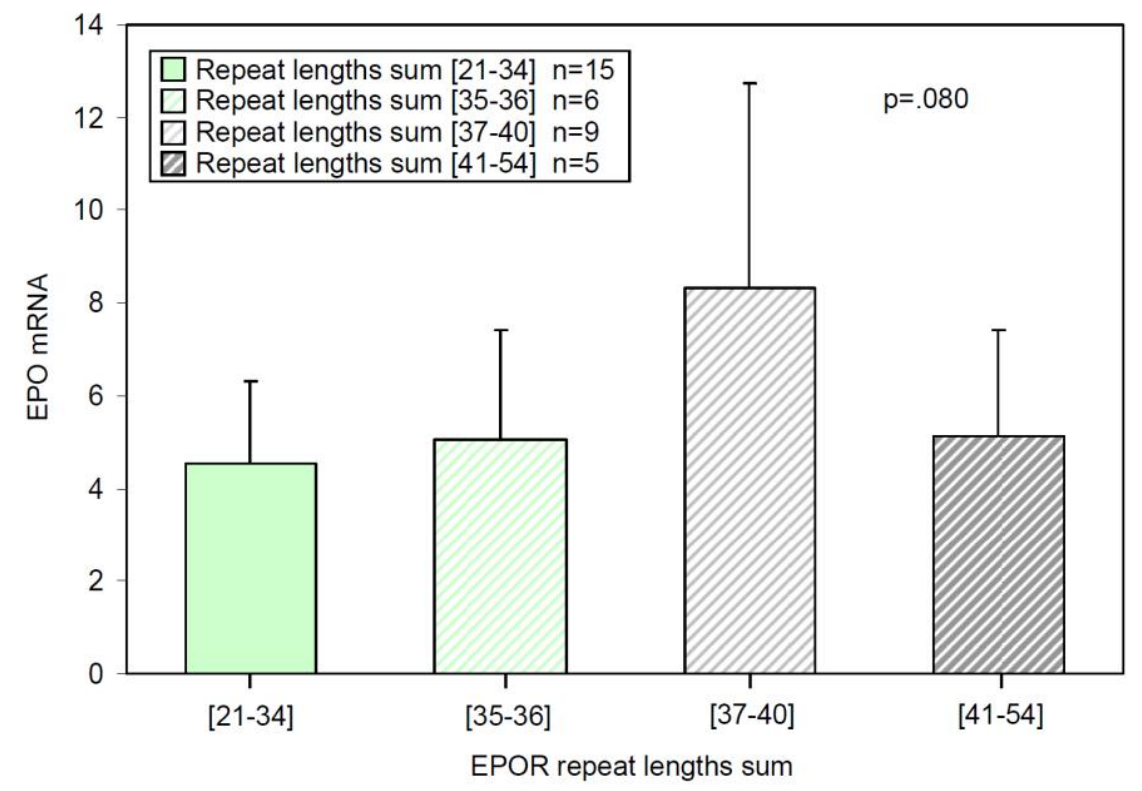

Figure 22: Effect of EPOR repeat separated in four different sum groups on EPO mRNA 


\section{Discussion}

The present thesis explored whether common genetic variants of the EPO system (EPO/EPOR) have an influence on cognitive core features in schizophrenia, e.g. speed of processing and verbal learning and memory. Like hypothesized a simple case control association study, based on endpoint diagnosis and single markers, did not yield significant differences between cases and controls regarding genotypic or allelic frequencies. Therefore neither EPO nor EPOR are qualified for the label "disease gene".

Instead, it could be shown that both genes are modifying cognition in schizophrenia and by that, have a considerable impact on the functional outcome of the disease (Green, 1996). Both were significantly associated with the cognitive composite score after correcting for age, medication, negative symptoms and duration of disease independent of each other, but also in interaction, even though the genes are located on different chromosomes. Concerning the single domains, the EPO SNP was not significantly associated with verbal learning and memory, but the trend pointed to that direction $(p=.082)$. For the EPOR marker, there was no single effect with speed of processing found. This might indicate that EPOR has more influence on a higher cognitive level.

In general, it is difficult to analyse short tandem repeats if they contain a large amount of allelic variants such as the STR $(\mathrm{GA})_{n}$ in the promoter region of EPOR with 23 alleles in the GRAS sample. The used approach was to add up both alleles with the idea that lower sums indicate lower repeat frequencies on both alleles and vice versa. Still, further analyses by splitting up the sum groups not only in high and low, but into four categories showed, that the influence of the repeat sum is not a continuing one but of a far more complex nature. One approach to further shed light on this strategy was to compare the four sum groups concerning their heterogeneity. Interestingly, the first of the four sum groups was the most heterogeneous group and cognitively the best group, followed by the fourth sum group with second-best cognitive results and second-high heterogeneity rates. Both sum groups in between had a worse outcome in cognitive tests and had comparably low levels of heterogeneity. To conclude, it seems to be most beneficial to have one allele with very few repeats and a medium quantity of repeats on the second allele, which might imply an influence of the EPOR STR $(\mathrm{GA})_{n}$ on transcriptional processes. To identify 
the exact pattern behind the number of repeats in EPOR, especially in interaction with EPO, a much bigger sample would be needed, which might even allow allelewise analyses.

To control for random associations which might only occur by chance due to the distribution of subjects among the genetic groups, three different types of control variables were used (cognitive, disease-related and disease-unrelated) and revealed no significant association, indeed. Therefore it might be justified saying that the genes of the EPO system are specifically modulating cognitive performance.

For all shown analyses, correction for multiple testing was abandoned, since they were carried out strictly hypothesis-driven and in an exploratory fashion and are in many ways not independent of each other: Both cognitive domains are not independent of each others, the composite score comprises results of the single domains and also the interaction effect is not to be handled as a third genetic marker since it depends on the group distributions of the single markers.

For a long time, changes in cognitive performance after administration of rhEpo have been attributed to stimulation of erythrocytosis which in turn enhanced tissue oxygenation (for review see Ehrenreich, et al., 2008), therefore it was necessary to evaluate whether the influence of EPO and EPOR markers on cognition goes along with an effect on basic blood parameters, e.g. hemoglobin, hematocrit, erythrocytes or thrombocytes. Values were collected from a 10 year time span and individual means were calculated most carefully with an exclusion of outliers and extreme values; neither EPO nor EPOR had a significant effect on any of the obtained blood values. Thus, it underlines the assumption that the effect of Epo on higher cognitive functions is independent of its role in erythropoiesis. The independence of the amount of red blood cells was also confirmed in transgenic cEPOR mice, which have constitutively active EPO receptors in the postnatal mouse forebrain. Their superior cognitive phenotype compared with wildtype mice (Sargin, et al., submitted) came along with an enhanced impulsivity. A translational approach was taken by testing the impulsivity in humans, and as expected an association with STR $(\mathrm{GA})_{n}$ of EPOR, but not with EPO or the interaction of both genes was found. Since the animal phenotype was also only due to a modification of the EPO receptor, this finding was an additional validation of the obtained results. 
From a psychological point of view it was to some degree surprising that the influence of EPOR STR on cognition and on impulsivity was on the same line, (e.g. good results in cognitive tests went along with high impulsivity rates and vice versa), since the majority of studies about the link between cognition and impulsivity found inverse relations in humans (Corr \& Kumari, 1998; Lynam, Moffitt, \& StouthamerLoeber, 1993; Schweizer, 2002; Whitney, Jameson, \& Hinson, 2004). While speculating about the reason for this seemingly contradictory finding, one has to keep in mind that impulsivity is a very complex construct which has been defined in many different ways (e.g. Buss \& Plomin, 1975; Cloninger, 1987; Eysenck \& Eysenck, 1985; Schalling, Asberg, Edman, \& Oreland, 1987). For a deeper understanding of the connection between different dimensions of impulsivity and cognition, special measurements of impulsivity have to be applied, such as the Dickman's Impulsivity Inventory (Dickman, 1990). The idea behind Dickmans inventory is that two forms of impulsivity exist: Functional impulsivity, which is characterized by quick and inaccurate responding in situations where it is rewarded, and dysfunctional impulsivity, which is described as a lack of inhibiting fast and thoughtless reactions in situations were they do not pay off. In his own studies he could show that high functional impulsives were faster and therefore gained better results than low functional impulsives in a task measuring the speed and accuracy of basic perceptual processes (Dickman, 1990). By subdividing the rough concept of impulsivity and furthermore introducing for the first time a useful variant of impulsivity, he shed new light on that field of research. The variety of concepts developed since in human as well as in rodent studies made clear: Impulsivity is a multifactor concept and several neurochemical mechanisms can influence different facets of impulsivity (Evenden, 1999). Therefore, one can conclude that measuring impulsivity with one item of the PANSS may have led to a rating of a functional form of impulsivity in the thesis on hand. The found association with the biologically meaningful subgroups of EPOR STR $(G A)_{n}$ suggests that the mechanism of action of EPOR repeat on cognition goes via neurochemical pathways involving among others a functional form of impulsivity, whilst the analysed EPO marker does not share this mechanism of action.

Concerning the mRNA findings, there is neither an influence of EPOR STR $(G A)_{n}$ on EPOR mRNA level nor of EPO SNP rs1617640 on its mRNA expression in PBMCs. The latter is in accordance with findings of Tong and co-workers (Tong, et al., 2008). 
Surprisingly, sum groups of EPOR STR $(\mathrm{GA})_{n}$ were significantly associated with EPO mRNA level in PBMCs in a subsample of 35 GRAS patients. Unfortunately, due to the small sample size $(n=35)$ the data could not be analyzed with respect to an interaction of both genotypes. For a better biological understanding this would be worthwhile. If this interaction can be replicated in bigger samples and as well allelewise, it would be a first step to understand the mechanism behind the interaction effect of both genes on cognition. The interaction seen on biological level mirrors exactly what was found in the cognitive test results - only in the opposite direction. In the light of the clinical studies where EPO treatment improves cognition (e.g. Ehrenreich, Fischer, et al., 2007; Ehrenreich, Hinze-Selch, et al., 2007; Neubauer, et al., 2010; Siren, et al., 2009) it is at first view unexpected, that higher levels of EPO lead to worse cognitive performance. The fact that in the vitreous body of diabetic patients as well as in luciferase reporter gene experiments the $T$ allele shows higher expression of EPO compared to the $G$ allele also points into that direction; accordingly, in the GRAS sample $T$ homozygotes have the worst cognitive results. Assuming a feedback regulation of EPO and EPOR, however, higher EPO mRNA levels may well point to a relative insufficiency (and thus compensatory upregulation) of the system.

The exact molecular mechanisms behind the EPO/EPOR system are still unknown. The fact that the analysed repeat in EPOR seems to have an influence only on the corresponding mRNA of EPO but not on its own mRNA, indicates that there is a complex regulation present in this system. Two possible scenarios might help to explain the mRNA findings, first regarding the quantity and second regarding quality of EPO/EPOR.

Having in mind that the STR in the EPOR gene is located in the $5^{\prime}$ flanking region and is neither transcribed nor translated, the regulation has to take place on DNA level. A real regulation at this stage has not been described so far, thus all further attempts to explain how EPOR STR might influence the mRNA of its ligand are speculative. The EPOR STR might lead to a differential binding of common transcription factors. In line with this speculation, the promoter regions of EPO and its receptor share some common binding sites (Chin, Oda, Shen, \& Noguchi, 1995; Fandrey, 2004). This could result in a competition of the mRNAs for specific transcription factors leading to differential expression. A further possibility is the 
existence of another variation in linkage to the analysed STR that affects the EPOR function and therefore leads to an upregulation of the ligand. It is well known, that single mutations in the EPOR gene can have a tremendous impact on the system. In PFCP it has been shown that modifications of a single amino acid can induce a hypersensitive phenotype (Arcasoy, et al., 1997). To prove this hypothesis in the GRAS study, homozygous carriers for different allele lengths would need to be analyzed in their expression and on the sequence level.

To conclude, it is hard to predict how common genetic variations such as STRs and SNPs influence expression or later the function of a gene. There is a variety of possibilities how single base pair exchanges or repeats in intronic regions or putative promoter regions can influence a phenotype. The found interaction effect between the analysed markers of EPO and EPOR genes is definitely worthwhile studying further. 


\section{Literature}

Abhary, S., Burdon, K. P., Casson, R. J., Goggin, M., Petrovsky, N. P., \& Craig, J. E. (2010). Association between erythropoietin gene polymorphisms and diabetic retinopathy. Arch Ophthalmol, 128(1), 102-106.

American Psychiatric Association. (1994). Diagnostic and statistical manual of mental disorders, 4th edition (DSM-IV). Washington, DC: American Psychiatric Press.

Arcasoy, M. O., Degar, B. A., Harris, K. W., \& Forget, B. G. (1997). Familial erythrocytosis associated with a short deletion in the erythropoietin receptor gene. Blood, 89(12), 4628-4635.

Balasubbu, S., Sundaresan, P., Rajendran, A., Ramasamy, K., Govindarajan, G., Perumalsamy, N., et al. (2010). Association Analysis of Nine Candidate Gene Polymorphisms in Indian Patients with Type 2 Diabetic Retinopathy. BMC Med Genet, 11(1), 158.

Barch, D. M., \& Keefe, R. S. (2010). Anticipating DSM-V: opportunities and challenges for cognition and psychosis. Schizophr Bull, 36(1), 43-47.

Begemann, M., Grube, S., Papiol, S., Malzahn, D., Krampe, H., Ribbe, K., et al. (2010). Modification of cognitive performance in schizophrenia by complexin 2 gene polymorphisms. Arch Gen Psychiatry, 67(9), 879-888.

Bellack, A. S., Sayers, M., Mueser, K. T., \& Bennett, M. (1994). Evaluation of social problem solving in schizophrenia. J Abnorm Psychol, 103(2), 371-378.

Blom, G. (1958). Statistical Estimates and Transformed Beta Variables. New York: John Wiley and Sons, Inc.

Bourantas, L. K., Chatzikyriakidou, A., Dasoula, A., Syrrou, M., Bournatas, K. L., \& Georgiou, I. (2006). Absence of mutations of the EPO-receptor gene in Greek patients with familial polycythemia. Eur J Haematol, 76(6), 537-538.

Brébion, G., Amador, X., Smith, M. J., \& Gorman, J. M. (1998). Memory impairment and schizophrenia: the role of processing speed. Schizophr Res, 30(1), 31-39.

Brébion, G., Smith, M. J., Gorman, J. M., Malaspina, D., Sharif, Z., \& Amador, X. (2000). Memory and schizophrenia: differential link of processing speed and selective attention with two levels of encoding. J Psychiatr Res, 34(2), 121127.

Buchanan, R. W., Holstein, C., \& Breier, A. (1994). The comparative efficacy and long-term effect of clozapine treatment on neuropsychological test performance. Biol Psychiatry, 36(11), 717-725.

Buss, A. H., \& Plomin, R. (1975). A temperament theory of personality development. New York: Wiley.

Cannon, T. D., Huttunen, M. O., Lonnqvist, J., Tuulio-Henriksson, A., Pirkola, T., Glahn, D., et al. (2000). The inheritance of neuropsychological dysfunction in twins discordant for schizophrenia. Am J Hum Genet, 67(2), 369-382.

Chin, K., Oda, N., Shen, K., \& Noguchi, C. T. (1995). Regulation of transcription of the human erythropoietin receptor gene by proteins binding to GATA-1 and Sp1 motifs. Nucleic Acids Res, 23(15), 3041-3049.

Cirillo, M. A., \& Seidman, L. J. (2003). Verbal declarative memory dysfunction in schizophrenia: from clinical assessment to genetics and brain mechanisms. Neuropsychol Rev, 13(2), 43-77.

Cloninger, C. R. (1987). A systematic method for clinical description and classification of personality variants. A proposal. Arch Gen Psychiatry, 44(6), 573-588.

Corr, P. J., \& Kumari, V. (1998). Impulsivity, Time of Day, and Stress: Effects on Intelligence Test Performance. Journal of Research in Personality, 32, 1-12. 
Corrigan, P. W., Green, M. F., \& Toomey, R. (1994). Cognitive correlates to social cue perception in schizophrenia. Psychiatry Res, 53(2), 141-151.

D'Andrea, A. D., Lodish, H. F., \& Wong, G. G. (1989). Expression cloning of the murine erythropoietin receptor. Cell, 57(2), 277-285.

Davis, J. M. (1976). Comparative doses and costs of antipsychotic medication. Arch Gen Psychiatry, 33(7), 858-861.

de la Chapelle, A., Sistonen, P., Lehvaslaiho, H., Ikkala, E., \& Juvonen, E. (1993). Familial erythrocytosis genetically linked to erythropoietin receptor gene. Lancet, 341(8837), 82-84.

Dianzani, I., Garelli, E., Dompe, C., Crescenzio, N., Locatelli, F., Schiliro, G., et al. (1996). Mutations in the erythropoietin receptor gene are not a common cause of Diamond-Blackfan anemia. Blood, 87(6), 2568-2572.

Dickinson, D., Ramsey, M. E., \& Gold, J. M. (2007). Overlooking the obvious: a metaanalytic comparison of digit symbol coding tasks and other cognitive measures in schizophrenia. Arch Gen Psychiatry, 64(5), 532-542.

Dickman, S. J. (1990). Functional and dysfunctional impulsivity: personality and cognitive correlates. J Pers Soc Psychol, 58(1), 95-102.

Duan, J., Sanders, A. R., \& Gejman, P. V. (2010). Genome-wide approaches to schizophrenia. [doi: DOI: 10.1016/j.brainresbull.2010.04.009]. Brain Research Bulletin, 83(3-4), 93-102.

Ehrenreich, H., Bartels, C., Sargin, D., Stawicki, S., \& Krampe, H. (2008). Recombinant human erythropoietin in the treatment of human brain disease: focus on cognition. J Ren Nutr, 18(1), 146-153.

Ehrenreich, H., Fischer, B., Norra, C., Schellenberger, F., Stender, N., Stiefel, M., et al. (2007). Exploring recombinant human erythropoietin in chronic progressive multiple sclerosis. Brain, 130(Pt 10), 2577-2588.

Ehrenreich, H., Hinze-Selch, D., Stawicki, S., Aust, C., Knolle-Veentjer, S., Wilms, S., et al. (2007). Improvement of cognitive functions in chronic schizophrenic patients by recombinant human erythropoietin. Mol Psychiatry, 12(2), 206-220.

Elvevag, B., \& Goldberg, T. E. (2000). Cognitive impairment in schizophrenia is the core of the disorder. Crit Rev Neurobiol, 14(1), 1-21.

Emanuel, P. D., Eaves, C. J., Broudy, V. C., Papayannopoulou, T., Moore, M. R., D'Andrea, A. D., et al. (1992). Familial and congenital polycythemia in three unrelated families. Blood, 79(11), 3019-3030.

Evenden, J. L. (1999). Varieties of impulsivity. Psychopharmacology, 146(4), 348361.

Eysenck, H. J., \& Eysenck, M. W. (1985). Personality and individual differences: a natural science approach. New York: Plenum Press.

Fandrey, J. (2004). Oxygen-dependent and tissue-specific regulation of erythropoietin gene expression. Am J Physiol Regul Integr Comp Physiol, 286(6), R977-988.

Furukawa, T., Narita, M., Sakaue, M., Otsuka, T., Kuroha, T., Masuko, M., et al. (1997). Primary familial polycythaemia associated with a novel point mutation in the erythropoietin receptor. Br J Haematol, 99(1), 222-227.

Ganesh, S. K., Zakai, N. A., van Rooij, F. J., Soranzo, N., Smith, A. V., Nalls, M. A., et al. (2009). Multiple loci influence erythrocyte phenotypes in the CHARGE Consortium. Nat Genet, 41(11), 1191-1198.

Ghezzi, S., Del Bo, R., Scarlato, M., Nardini, M., Carlesi, C., Prelle, A., et al. (2009). Is erythropoietin gene a modifier factor in amyotrophic lateral sclerosis? [doi: DOI: 10.1016/j.neurobiolaging.2007.08.008]. Neurobiology of Aging, 30(5), 842-844. 
Gold, J. M., Rehkemper, G., Binks, S. W., 3rd, Carpenter, C. J., Fleming, K., Goldberg, T. E., et al. (2000). Learning and forgetting in schizophrenia. $J$ Abnorm Psychol, 109(3), 534-538.

Green, M. F. (1996). What are the functional consequences of neurocognitive deficits in schizophrenia? Am J Psychiatry, 153(3), 321-330.

Green, M. F. (2006). Cognitive impairment and functional outcome in schizophrenia and bipolar disorder. J Clin Psychiatry, 67 Supp/ 9, 3-8; discussion 36-42.

Grimm, G., Stockenhuber, F., Schneeweiss, B., Madl, C., Zeitlhofer, J., \& Schneider, B. (1990). Improvement of brain function in hemodialysis patients treated with erythropoietin. Kidney Int, 38(3), 480-486.

Grube, S., Gerchen, M. F., Adamcio, B., Pardo, L. A., Martin, S., Mahlzahn, D., et al. (submitted). Calcium-activated potassium channels as regulators of cognitive performance in schizophrenia.

Hardy, J., \& Singleton, A. (2009). Genomewide Association Studies and Human Disease. New England Journal of Medicine, 360(17), 1759-1768.

Hegarty, J., Baldessarini, R., Tohen, M., Waternaux, C., \& Oepen, G. (1994). One hundred years of schizophrenia: a meta-analysis of the outcome literature. $A m$ J Psychiatry, 151(10), 1409-1416.

Heinrichs, R. W., \& Zakzanis, K. K. (1998). Neurocognitive deficit in schizophrenia: a quantitative review of the evidence. Neuropsychology, 12(3), 426-445.

Helmstaedter, C., Lendt, M., \& Lux, S. (2001). Verbaler Lern- und Merkfähigkeitstest (VLMT). Goettingen: Beltz.

Hengemihle, J. M., Abugo, O., Rifkind, J., Spangler, E., Danon, D., \& Ingram, D. K. (1996). Chronic treatment with human recombinant erythropoietin increases hematocrit and improves water maze performance in mice. Physiol Behav, 59(1), 153-156.

Hess, G., Rose, P., Gamm, H., Papadileris, S., Huber, C., \& Seliger, B. (1994). Molecular analysis of the erythropoietin receptor system in patients with polycythaemia vera. Br J Haematol, 88(4), 794-802.

Hoff, A. L., Sakuma, M., Wieneke, M., Horon, R., Kushner, M., \& DeLisi, L. E. (1999). Longitudinal neuropsychological follow-up study of patients with first-episode schizophrenia. Am J Psychiatry, 156(9), 1336-1341.

Iliadou, A., Evans, D. M., Zhu, G., Duffy, D. L., Frazer, I. H., Montgomery, G. W., et al. (2007). Genomewide scans of red cell indices suggest linkage on chromosome 6q23. J Med Genet, 44(1), 24-30.

Jacobs, K., Shoemaker, C., Rudersdorf, R., Neill, S. D., Kaufman, R. J., Mufson, A., et al. (1985). Isolation and characterization of genomic and cDNA clones of human erythropoietin. Nature, 313(6005), 806-810.

Javitt, D. C., Strous, R. D., Grochowski, S., Ritter, W., \& Cowan, N. (1997). Impaired precision, but normal retention, of auditory sensory ("echoic") memory information in schizophrenia. J Abnorm Psychol, 106(2), 315-324.

Jedlickova, K., Stockton, D. W., Chen, H., Stray-Gundersen, J., Witkowski, S., Ri-Li, G., et al. (2003). Search for genetic determinants of individual variability of the erythropoietin response to high altitude. Blood Cells Mol Dis, 31(2), 175-182.

Juul, S. E., Yachnis, A. T., Rojiani, A. M., \& Christensen, R. D. (1999). Immunohistochemical localization of erythropoietin and its receptor in the developing human brain. Pediatr Dev Pathol, 2(2), 148-158.

Kay, S. R., Fiszbein, A., \& Opler, L. A. (1987). The positive and negative syndrome scale (PANSS) for schizophrenia. Schizophr Bull, 13(2), 261-276.

Keefe, R. S., Eesley, C. E., \& Poe, M. P. (2005). Defining a cognitive function decrement in schizophrenia. Biol Psychiatry, 57(6), 688-691. 
Keefe, R. S., \& Fenton, W. S. (2007). How should DSM-V criteria for schizophrenia include cognitive impairment? Schizophr Bull, 33(4), 912-920.

Kern, R. S., Nuechterlein, K. H., Green, M. F., Baade, L. E., Fenton, W. S., Gold, J. M., et al. (2008). The MATRICS Consensus Cognitive Battery, part 2: conorming and standardization. Am J Psychiatry, 165(2), 214-220.

Knapp, M., Mangalore, R., \& Simon, J. (2004). The global costs of schizophrenia. Schizophr Bull, 30(2), 279-293.

Koh, S. D., Kayton, L., \& Berry, R. (1973). Mnemonic organization in young nonpsychotic schizophrenics. J Abnorm Psychol, 81(3), 299-310.

Koury, M. J., Bondurant, M. C., Graber, S. E., \& Sawyer, S. T. (1988). Erythropoietin messenger RNA levels in developing mice and transfer of 125I-erythropoietin by the placenta. J Clin Invest, 82(1), 154-159.

Koury, S. T., Bondurant, M. C., Koury, M. J., \& Semenza, G. L. (1991). Localization of cells producing erythropoietin in murine liver by in situ hybridization. Blood, 77(11), 2497-2503.

Kraepelin, E. (1893). Psychiatrie. Leipzig: J. A. Barth.

Kralovics, R., Sokol, L., Broxson, E. H., Jr., \& Prchal, J. T. (1997). The erythropoietin receptor gene is not linked with the polycythemia phenotype in a family with autosomal dominant primary polycythemia. Proc Assoc Am Physicians, 109(6), 580-585.

Kralovics, R., Sokol, L., \& Prchal, J. T. (1998). Absence of polycythemia in a child with a unique erythropoietin receptor mutation in a family with autosomal dominant primary polycythemia. J Clin Invest, 102(1), 124-129.

Lehrl, S. (1999). Mehrfach-Wortschatz-Intelligenztest MWT-B. Balingen: Spitta Verlag.

Lehrl, S., Triebig, G., \& Fischer, B. (1995). Multiple choice vocabulary test MWT as a valid and short test to estimate premorbid intelligence. Acta Neurol Scand, 91(5), 335-345.

Lin, J. P., O'Donnell, C. J., Levy, D., \& Cupples, L. A. (2005). Evidence for a gene influencing haematocrit on chromosome 6q23-24: genomewide scan in the Framingham Heart Study. J Med Genet, 42(1), 75-79.

Lynam, D., Moffitt, T., \& Stouthamer-Loeber, M. (1993). Explaining the relation between IQ and delinquency: class, race, test motivation, school failure, or self-control? J Abnorm Psychol, 102(2), 187-196.

Ma, W., Kantarjian, H., Zhang, K., Zhang, X., Wang, X., Chen, C., et al. (2010). Significant association between polymorphism of the erythropoietin gene promoter and myelodysplastic syndrome. BMC Med Genet, 11(1), 163.

Matarazzo, J. D., \& Herman, D. O. (1984). Base rate data for the WAIS-R: test-retest stability and VIQ-PIQ differences. J Clin Neuropsychol, 6(4), 351-366.

Mejia, O. M., Prchal, J. T., Leon-Velarde, F., Hurtado, A., \& Stockton, D. W. (2005). Genetic association analysis of chronic mountain sickness in an Andean highaltitude population. Haematologica, 90(1), 13-19.

Mittelman, M., Gardyn, J., Carmel, M., Malovani, H., Barak, Y., \& Nir, U. (1996). Analysis of the erythropoietin receptor gene in patients with myeloproliferative and myelodysplastic syndromes. Leuk Res, 20(6), 459-466.

Neubauer, A. P., Voss, W., Wachtendorf, M., \& Jungmann, T. (2010). Erythropoietin improves neurodevelopmental outcome of extremely preterm infants. Ann Neurol, 67(5), 657-666.

Nuechterlein, K. H., Dawson, M. E., \& Green, M. F. (1994). Information-processing abnormalities as neuropsychological vulnerability indicators for schizophrenia. Acta Psychiatr Scand Suppl, 384, 71-79. 
O'Donovan, M. C., Craddock, N., Norton, N., Williams, H., Peirce, T., Moskvina, V., et al. (2008). Identification of loci associated with schizophrenia by genome-wide association and follow-up. Nat Genet, 40(9), 1053-1055.

Palmer, B. W., Heaton, R. K., Paulsen, J. S., Kuck, J., Braff, D., Harris, M. J., et al. (1997). Is it possible to be schizophrenic yet neuropsychologically normal? Neuropsychology, 11(3), 437-446.

Papiol, S., Begemann, M., Rosenberger, A., Friedrichs, H., Ribbe, K., Grube, S., et al. (2011). A phenotype-based genetic association study reveals the contribution of neuregulin1 gene variants to age of onset and positive symptom severity in schizophrenia. American Journal of Medical Genetics Part B: Neuropsychiatric Genetics, Epub ahead of print.

Patel, A., Everitt, B., Knapp, M., Reeder, C., Grant, D., Ecker, C., et al. (2006). Schizophrenia patients with cognitive deficits: factors associated with costs. Schizophr Bull, 32(4), 776-785.

Percy, M. J., McMullin, M. F., \& Lappin, T. R. (1997). Sequence analysis of the 3' hypoxia-responsive element of the human erythropoietin gene in patients with erythrocytosis. Biochem Mol Med, 62(1), 132-134.

Percy, M. J., McMullin, M. F., Roques, A. W., Westwood, N. B., Acharya, J., Hughes, A. E., et al. (1998). Erythrocytosis due to a mutation in the erythropoietin receptor gene. Br J Haematol, 100(2), 407-410.

Petersen, K. B., Hokland, P., Petersen, G. B., \& Nyvold, C. G. (2004). Erythropoietin receptor defect: a cause of primary polycythaemia. Br J Haematol, 125(4), 537-538.

Rabie, T., \& Marti, H. H. (2008). Brain protection by erythropoietin: a manifold task. Physiology (Bethesda), 23, 263-274.

Reichenberg, A., Weiser, M., Rabinowitz, J., Caspi, A., Schmeidler, J., Mark, M., et al. (2002). A population-based cohort study of premorbid intellectual, language, and behavioral functioning in patients with schizophrenia, schizoaffective disorder, and nonpsychotic bipolar disorder. Am J Psychiatry, 159(12), 2027-2035.

Rey, A. (1958). L'Examen Clinique en Psychologie. Paris: Press Universitaire de France.

Ribbe, K., Ackermann, V., Schwitulla, J., Begemann, M., Papiol, S., Grube, S., et al. (submitted). Interaction of common genetic variants in the corticotropin releasing factor system predicts the risk of comorbid alcoholism.

Ribbe, K., Friedrichs, H., Begemann, M., Grube, S., Papiol, S., Kästner, A., et al. (2010). The cross-sectional GRAS sample: A comprehensive phenotypical data collection of schizophrenic patients. BMC Psychiatry, Nov 10; 10(1):91. Epub ahead of print (2010).

Rodriguez-Sanchez, J. M., Crespo-Facorro, B., Gonzalez-Blanch, C., Perez-Iglesias, R., \& Vazquez-Barquero, J. L. (2007). Cognitive dysfunction in first-episode psychosis: the processing speed hypothesis. Br J Psychiatry Suppl, 51, s107110.

Sargin, D., El-Kordi, A., Agarwal, A., Müller, M., Wojcik, S. M., Hassouna, I., et al. (submitted). Expression of constitutively active erythropoietin receptor in cortical neurons boosts higher cognitive functions in mice.

Sargin, D., Friedrichs, H., El-Kordi, A., \& Ehrenreich, H. (2010). Erythropoietin as neuroprotective and neuroregenerative treatment strategy: Comprehensive overview of 12 years of preclinical and clinical research. Best Practice \& Research Clinical Anaesthesiology, 24, 573-594. 
Saykin, A. J., Shtasel, D. L., Gur, R. E., Kester, D. B., Mozley, L. H., Stafiniak, P., et al. (1994). Neuropsychological deficits in neuroleptic naive patients with firstepisode schizophrenia. Arch Gen Psychiatry, 51(2), 124-131.

Schalling, D., Asberg, M., Edman, G., \& Oreland, L. (1987). Markers for vulnerability to psychopathology: temperament traits associated with platelet MAO activity. Acta Psychiatr Scand, 76(2), 172-182.

Schweizer, K. (2002). Does impulsivity influence performance in reasoning? [doi: DOI: 10.1016/S0191-8869(01)00209-4]. Personality and Individual Differences, 33(7), 1031-1043.

Siren, A. L., Fasshauer, T., Bartels, C., \& Ehrenreich, H. (2009). Therapeutic potential of erythropoietin and its structural or functional variants in the nervous system. Neurotherapeutics, 6(1), 108-127.

Siren, A. L., Knerlich, F., Poser, W., Gleiter, C. H., Bruck, W., \& Ehrenreich, H. (2001). Erythropoietin and erythropoietin receptor in human ischemic/hypoxic brain. Acta Neuropathol, 101(3), 271-276.

Sokol, L., Luhovy, M., Guan, Y., Prchal, J. F., Semenza, G. L., \& Prchal, J. T. (1995). Primary familial polycythemia: a frameshift mutation in the erythropoietin receptor gene and increased sensitivity of erythroid progenitors to erythropoietin. Blood, 86(1), 15-22.

Sokol, L., Prchal, J., \& Prchal, J. T. (1993). Primary familial and congenital polycythaemia. Lancet, 342(8863), 115-116.

SPSS Inc. from http://www.spss.com/

Sripichai, O., Whitacre, J., Munkongdee, T., Kumkhaek, C., Makarasara, W., Winichagoon, P., et al. (2005). Genetic analysis of candidate modifier polymorphisms in $\mathrm{Hb}$ E-beta 0-thalassemia patients. Ann N Y Acad Sci, 1054, 433-438.

Tewes, U. (1991). Hamburg-Wechsler Intelligenztest fuer Erwachsene (HAWIE-R). Bern: Huber.

Tilbrook, P. A., \& Klinken, S. P. (1999). Erythropoietin and erythropoietin receptor. Growth Factors, 17(1), 25-35.

Tong, Z., Yang, Z., Patel, S., Chen, H., Gibbs, D., Yang, X., et al. (2008). Promoter polymorphism of the erythropoietin gene in severe diabetic eye and kidney complications. Proc Natl Acad Sci U S A, 105(19), 6998-7003.

Watowich, S. S., Xie, X., Klingmuller, U., Kere, J., Lindlof, M., Berglund, S., et al. (1999). Erythropoietin receptor mutations associated with familial erythrocytosis cause hypersensitivity to erythropoietin in the heterozygous state. Blood, 94(7), 2530-2532.

Wechsler, D. (1981). Manual for the Wechsler Adult Intelligence Scale-Revised. New York: The Psychological Corp.

Wechsler, D. (1997). Wechsler Adult Intelligence Scale (WAIS-III) (3 ed.). San Antonio, TX: The Psychological Corporation.

Whitney, P., Jameson, T., \& Hinson, J. M. (2004). Impulsiveness and executive control of working memory. [doi: DOI: 10.1016/j.paid.2003.09.013]. Personality and Individual Differences, 37(2), 417-428.

Wilk, C. M., Gold, J. M., McMahon, R. P., Humber, K., lannone, V. N., \& Buchanan, R. W. (2005). No, it is not possible to be schizophrenic yet neuropsychologically normal. Neuropsychology, 19(6), 778-786.

World Health Organization. (1992). The ICD-10 classification of mental and behavioural disorders: Clinical descriptions and diagnostic guidelines. Geneva: WHO. 
Wüstenberg, T., Begemann, M., Bartels, C., Gefeller, O., Stawicki, S., Hinze-Selch, D., et al. (2010). Recombinant human erythropoietin delays loss of gray matter in chronic schizophrenia. Mol Psychiatry.

Zeng, S. M., Yankowitz, J., Widness, J. A., \& Strauss, R. G. (2001). Etiology of differences in hematocrit between males and females: sequence-based polymorphisms in erythropoietin and its receptor. J Gend Specif Med, 4(1), 3540. 
Supplement A

ZAHLEN-SYMBOL-TEST

(HAWIE-R)

90 Sekunden Bearbeitungszeit

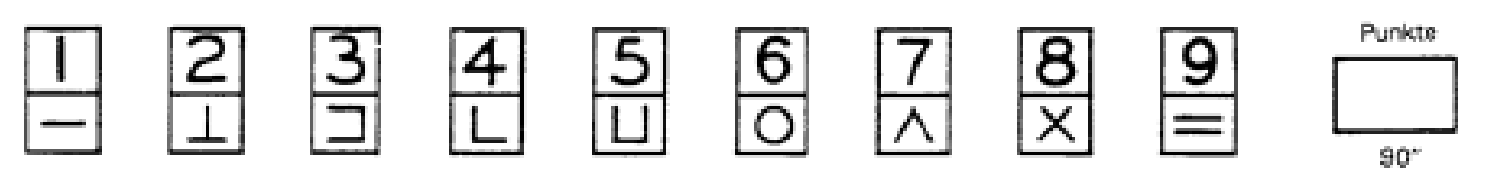

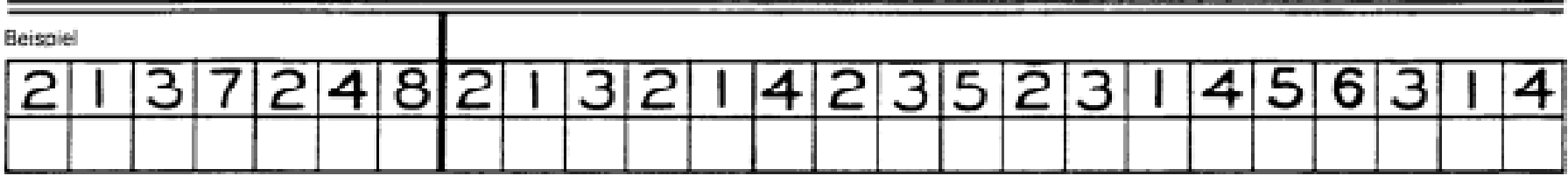

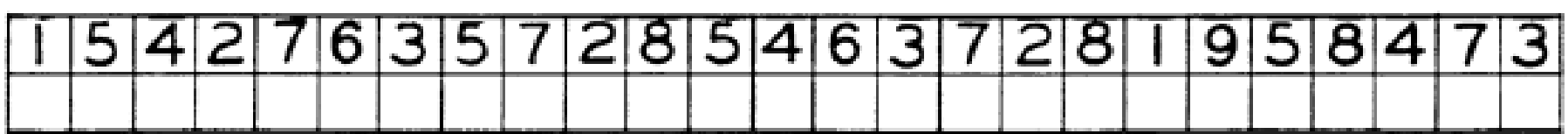

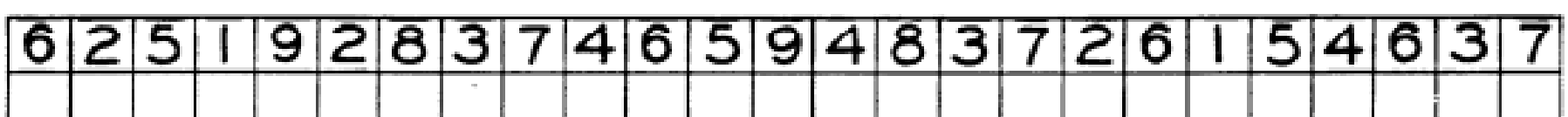

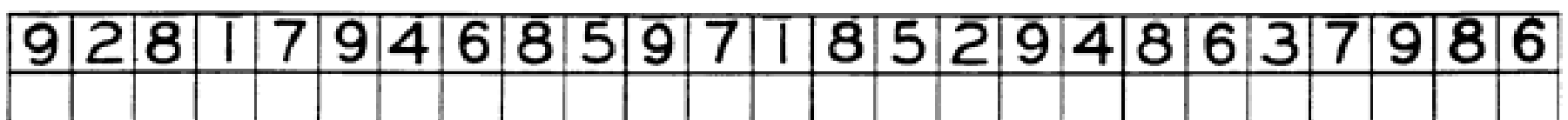




\section{Supplement B}

\begin{tabular}{|c|c|c|c|c|c|c|c|c|c|c|}
\hline \multicolumn{11}{|c|}{ VLMT - FORM A } \\
\hline Liste A & Dg1 & Dg2 & Dg3 & $\mathrm{Dg} 4$ & Dg5 & Liste B & 1 & Dg6 & Dg7 & \\
\hline Trommel & & & & & & Tisch & & & & Trommel \\
\hline Vorhang & & & & & & Förster & & & & Vorhang \\
\hline Glocke & & & & & & Vogel & & & & Glocke \\
\hline Kaffee & & & & & & Schuh & & & & Kaffee \\
\hline Schule & & & & & & Ofen & & & & Schule \\
\hline Eltern & & & & & & Berg & & & & Eltern \\
\hline Mond & & & & & & Handtuch & & & & Mond \\
\hline Garten & & & & & & Brille & & & & Garten \\
\hline Hut & & & & & & Wolke & & & & Hut \\
\hline Bauer & & & & & & Boot & & & & Bauer \\
\hline Nase & & & & & & Lamm & & & & Nase \\
\hline Truthahn & & & & & & Gewehr & & & & Truthahn \\
\hline Farbe & & & & & & Bleistift & & & & Farbe \\
\hline Haus & & & & & & Kirsche & & & & Haus \\
\hline Fluß & & & & & & Arm & & & & Fluß \\
\hline \multicolumn{11}{|c|}{ Weitere Nennungen: } \\
\hline & & & & & & & & & & \\
\hline & & & & & & & & & & \\
\hline & & & & & & & & & & \\
\hline & & & & & & & & & & \\
\hline & & & & & & & & & & \\
\hline
\end{tabular}

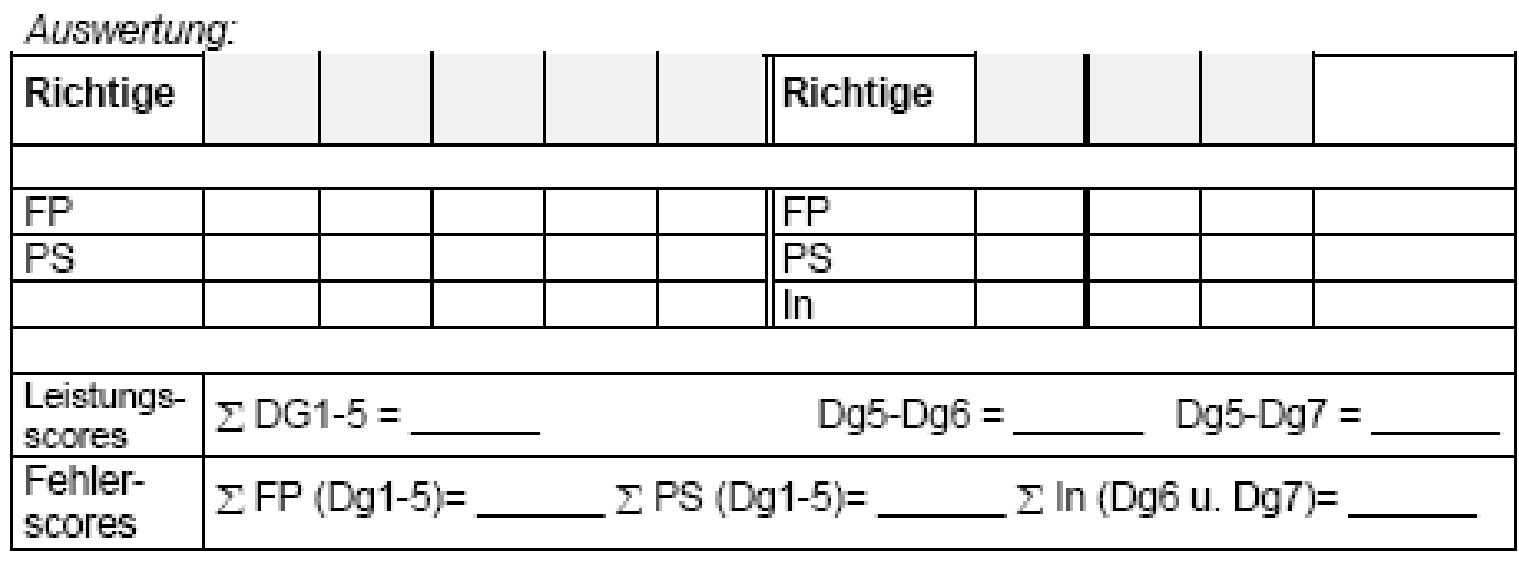

\section{Anmerkung zu den Fehlertypen:}

FP= Falsch Positive: Wörter, die weder in der Lern- noch in der Interferenzliste vorkommen.

PS = Perseverationen: Mehrfachnennungen derselben Wörter während eines Lerndurchgangs

In = Interferenzen:

(unabhängig davon, ob sie den dargebotenen Listen entstammen).

Wörter aus der gerade nicht relevanten Wortliste (Lern- oder Interferenzliste). 


\section{Supplement C}

Sargin, D., Friedrichs, H., El-Kordi, A., \& Ehrenreich, H. (2010). Erythropoietin as neuroprotective and neuroregenerative treatment strategy: Comprehensive overview of 12 years of preclinical and clinical research. Best Practice \& Research Clinical Anaesthesiology, 24, 573-594.

Due to copyright reasons, please check the journals homepage

http://www.elsevier.com/wps/find/journaldescription.cws home/623000/description\#description 


\section{Supplement D}

Ribbe, K., Friedrichs, H., Begemann, M., Grube, S., Papiol, S., Kästner, A., et al. (2010). The cross-sectional GRAS sample: A comprehensive phenotypical data collection of schizophrenic patients. BMC Psychiatry, Nov 10; 10(1):91.Epub ahead of print (2010).

Due to copyright reasons, please check PubMed

PMID: 21067598 


\section{Curriculum Vitae}

Heidi Friedrichs

Max Planck Institute of Experimental Medicine

Division of Clinical Neuroscience

Hermann-Rein-Str. 3

37075 Göttingen

Germany

Phone: +49 (551) 3899-586

Fax: $\quad+49$ (551) 3899-670

E-mail: Heidi_Friedrichs@gmx.de

\section{Education}

since Nov 2007 PhD student - Center for Systems Neuroscience, Graduate

School for Neuroscience and Molecular Biosciences,

Göttingen, Germany

working under Professor Hannelore Ehrenreich at the

Max Planck Institute for Experimental Medicine,

Göttingen, Germany

Feb 2007 Diploma in Psychology, Friedrichs-Wilhelms-University, Bonn, Germany

June $2001 \quad$ German "Abitur” at the Ernst-Moritz-Arndt Gymnasium, Remscheid, Germany

Work and practical experience

Aug - Nov 2006 working as tutor for 'InWEnt - Internationale Weiterbildung und Entwicklung gGmbH', Bonn, Germany

Oct - Dec 2005 Internship at the 'Institut für Psychologische Unfallnachsorge' (ipu), Köln, Germany

Oct - Dec 2004 Internship at a practice for psychological assessments, Dohrenbusch \& Meise GbR, Bonn, Germany

March - April 2004 Internship at the psychological counselling service of the Diakonie Wuppertal-Elberfeld, Germany 


\section{Publications}

Ribbe, K.* Friedrichs, H. ${ }^{*}$, Begemann, M. ${ }^{*}$, et al. The cross-sectional GRAS sample: A comprehensive phenotypical data collection of schizophrenic patients. BMC Psychiatry, Nov 10; 10 (1):91.Epub ahead of print (2010).

* equally contributing first authors

Sargin, D., Friedrichs, H., El-Kordi, A. \& Ehrenreich, H. Erythropoietin as neuroprotective and neuroregenerative treatment strategy: Comprehensive overview of 12 years of preclinical clinical research. Best Pract Res Clin Anaesthesiol. 24, 573-594 (2010).

Begemann, M., Klaus, S., Papiol, S., Malzahn, D., Krampe, H., Ribbe, K., Friedrichs, H., et al. Complexin2 gene polymorphisms modify cognitive performance in schizophrenia. Arch Gen Psychiatry, 67(9), 879-888 (2010).

Papiol, S., Begemann, M., Rosenberger, A., Friedrichs, H. et al. A phenotype-based genetic association study reveals the contribution of neuregulin1 gene variants to age of onset and positive symptom severity in schizophrenia. Am J Med Genet B Neuropsychiatr Genet, Epub ahead of print (2011).

Grube, S., Gerchen, M.F., Adamcio, B., Pardo, L.A., Martin, S., Malzahn, D., Papiol, S., Begemann, M., Ribbe, K., Friedrichs, H., et al. A CAG repeat polymorphism of KCNN3 predicts SK3 channel function and cognitive performance in schizophrenia. In revision.

Ribbe, K., Ackermann, V., Schwitulla, J., Begemann, M., Papiol, S., Grube, S., Sperling, S., Friedrichs, H., et al. Interaction of common genetic variants in the corticotropin releasing factor system predicts the risk of comorbid alcoholism. Submitted.

\section{Conference Abstracts}

Ribbe, K., Friedrichs, H., Hilmes, C., Begemann, M., Gerchen, M. F., Ghorbani, M., et al. (2008). The Data Collection of GRAS (Göttingen Research Association for Schizophrenia): Multi-Center Cross-Sectional Schizophrenia Study. Poster presented at the Robert Sommer Award Symposium, Giessen.

Friedrichs, H., Grube, S., El-Kordi, A., Schwitulla, J., Sargin, D., Begemann, M., et al. (2010). Genetic variants of EPO and EPOR influence cognitive core features of schizophrenia. Poster presented at the Annual Congress of the German Association for Psychiatry and Psychotherapy, Berlin. 